\title{
CATION TRANSPORT AND COCHLEAR FUNCTION
}



CATION TRANSPORT AND COCHLEAR FUNCTION 
PROMOTORES :

Prof. Dr. S. L. BONTING

EN

Prof. Dr. W. F. B. BRINKMAN 


\section{CATION TRANSPORT AND COCHLEAR FUNCTION}

\section{PROEFSCHRIFT}

TER VERKRIJGING VAN DE GRAAD VAN DOCTOR IN DE WISKUNDE EN NATUURWETENSCHAPPEN

AAN DE KATHOLIEKE UNIVERSITEIT TE NIJMEGEN,

OP GEZAG VAN DE RECTOR MAGNIFICUS DR. G. BRENNINKMEIJER,

HOOGLERAAR IN DE FACULTEIT DER SOCIALE WETENSCHAPPEN, VOLGENS BESLUIT VAN DE SENAAT IN HET OPENBAAR TE VERDEDIGEN OP VRIJDAG 19 DECEMBER 1969 DES NAMIDDAGS TE 2 UUR

DOOR

WILLIBRORDUS KUIJPERS

GEBOREN

TE KLOOSTERZANDE 
I am greatly indebted to Dr. J. F. G. Slegers for his interest and many valuable discussions throughout the course of this investigation. The technical assistance of Miss A. C. H. Janssen, Mr. A. C. van der Vleuten and Mr. P. Spaan and co-workers was greatly appreciated. I also wish to express my gratitude to Miss. A. E. Gonsalves and Miss. G. Kuijpers for typing and to Mrs. M. Duncan for correcting the manuscript.

The diagrams were prepared by $\mathrm{Mr} \mathrm{W}$. Maas and Mr. C. Reckers and the microphotographs by Mr. A. Reijnen of the department of medical illustration. 
Aan mijn Ouders.

1 Thea, Annemarie, Katrien

en Michiel. 
CHAPTER I ANATOMY OF THE COCHLEA

1. Introduction.

2 Gross anatomy of the labyrinth . . . 11

3. Anatomy of the mammalian cochlea . . 12

4. The lateral wall of the scala media . . . 14

5. The vestibular wall of the scala media. . 16

6 The tympanal wall of the scala media . . 17

$\begin{array}{ll}\text { 7. The ligamentum spirale and limbus spiralis . } & 19\end{array}$

8. Vascularisation . . . . . . . . . 19

9 Innervation . . . . . . . . . . 20

10 Saccus endolymphaticus . . . . . . . . 20

11 Anatomy of the avian cochlea . . . . 21

CHAPTER II THE COCHLEAR FLUIDS

1. Introduction . . . . . . . . . . . 23

2. Composition . . . . $\quad$. . . . . $\quad . \quad . \quad . \quad .23$

3. Origin and circulation . $\quad$. $\quad . \quad . \quad . \quad . \quad . \quad . \quad . \quad 24$

a. Perlymph . . . $\quad$. . . . . . $\quad$. . . . 24

b. Endolymph . . . . $\quad$. . . . . . $\quad . \quad$. . . 25

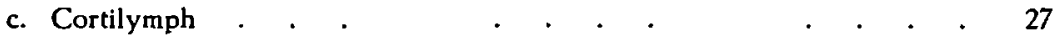

CHAPTER III ELECTRICAL PHENOMENA IN THE MAMMALIAN COCHLEA

1. Introduction . . . . . . . . . . . $\quad$. $\quad 28$

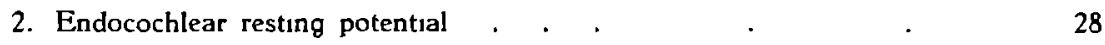

3. Intracellular DC polarisations . . . . . . . 30

4. Cochlear microphonic potential . . . . . . $\quad 31$

5. Electrical phenomena in the avian cochlea . . 33

CHAPTER IV CATION TRANSPORT AND THE $\mathrm{Na}^{+}-\mathrm{K}^{+}$-ATPase SYSTEM

1. Introduction . . . . . . . . . . . . . . . . 34

2. Distribution of the $\mathrm{Na}^{+}-\mathrm{K}^{+}-\mathrm{ATP}$ ase system and correlation with cation transport . . . . . . . . . . . . . . . . 34

3. Properties of the $\mathrm{Na}^{+}-\mathrm{K}^{+}$-ATPase system . . . . . . . . 35

4. Function of the $\mathrm{Na}^{+} \mathrm{K}^{+}-\mathrm{ATP}$ ase system . . . . . . . . . 37

5. Mechanism of the $\mathrm{Na}^{+}-\mathrm{K}^{+}$-ATPase system . . . . . . . . 37

6. Purpose of this investigation. . . . . . . . . . . . . . 38

\section{CHAPTER V MATERIALS AND METHODS}

1. Materials

2. Brochemical assays. . . $\quad 39$

a. Anımals . . . . $\quad$. 39

b. Tissue preparation . $\quad 39$

c. ATPase determinations . 42 
3. Potentral recording

a. Surgical procedure . . . . . . . 44

b. Cochlear microphonic potential . . . . 44

c. Endolymphatic resting potential . . . . 45

d. Perfusion technique . . . . . . . 46

CHAPTER VI- OCCURRENCE AND DISTRIBUTION OF THE $\mathrm{Na}^{+}-\mathrm{K}^{+}$-ATPase ACTIVITY IN THE CHICKEN COCHLEA

1 Introduction . . . . . . . . . . . . . . . 48

2 Distribution of the $\mathrm{Na}^{+}-\mathrm{K}^{+}$-ATPase activity in the chicken cochlea . 48

3. Properties of ATPase actuvity . . . . . . . . . . 49

4. Discussion and conclusions . . . . . . . . . . 52

CHAPTER VII OCCURRENCE AND DISTRIBUTION OF

$\mathrm{Na}^{+} \mathrm{K}^{+}$-ATPase ACTIVITY IN THE COCHLEAR

STRUCTURES OF THE GUINEA PIG

1 Introduction . . . . . . . . . . . . . . . . 56

2. Presence and properties of the $\mathrm{Na}^{+}-\mathrm{K}^{+}$-ATPase system . . . . . 56

3. Distribution of ATPase activities of the various cochlear structures . . 61

4. Discussion and conclusions . . . . . . . . . . . 65

CHAPTER VIII THE EFFECT OF OUABAIN ON THE COCHLEAR POTENTIALS OF THE GUINEA PIG

1. Introduction .

2. Cochlear microphonic potential . . . . . . 70

3 Endolymphatic resting potential . $\quad . \quad$. . . . . . 73

4. Discussion and conclusions . . . . . . . . . . 76

CHAPTER IX THE NATURE OF THE ENDOLYMPHATIC RESTING POTENTIAL AND COMPOSITION OF THE PERILYMPH

1. Introduction

2. Effect of electrolyte changes in the perilymph . . . . 81

3. Effect of $\mathrm{pH}$ on the potentral . . . . . . . . 85

4. Experimental effects on the nature of the negative potential . 86

5. Discussion and conclusions. . . . . . . . . 88

SUMMARY . . . $\quad 94$

SAMENVATTING . $\quad 96$

$\begin{array}{llll}\text { REFERENCES . } & \text { • } & 98\end{array}$ 



\section{GENERAL INTRODUCTION}

The cochlea is a very complicated structure composed of two compartments filled with fluid and lined with various kinds of epithelium One of the most unusual phenomena of this organ is the intracellular-like ionic composition of one of these fluids, the endolymph This situation is unique among extracellular body fluids Moreover, several remarkable electrical phenomena, intimately connected with cochlear function, and dependent on the ionic composition of the fluids, can be measured in this organ

In this investigation we have investigated the identity, location and role of the cation pump maintaining the characteristic cationic composition of the endolymph, and participating in the generation of the cochlear potentials The first part of this thesis consists of a survey of the literature dealing with the histology and histochemistry of the cochlear structures and with the cochlear fluids and potentials In addition the $\mathrm{Na}^{+}-\mathrm{K}^{+}$-activated ATPase system and its relation to cation transport is reviewed The second part, dealing with our experiments, describes the experimental procedures and the results obtained and gives the discussion and conclusions of these results. 



\section{ANATOMY OF THE COCHLEA}

\section{Introduction}

Our present knowledge of the development and structure of the cochlear tissues is derived from a series of light microscopic investigations (Held, 1926, Bast and Anson, 1949) and more specifically from electronmicroscopic studies performed during the last fifteen years (Smith, 1957. Rodriguez Echandia and Burgos, 1965; Engstrom et al., 1966; Iurato, 1967a, b).

In this chapter the fine structure of the cochlear tissues is described in addition to the general organisation of the whole labyrinth.

\section{Gross anatomy of the labyrinth}

The membranous labyrinth originates from the otic placode, an epithelial thickening in the region of the rhombencephalon in early embryonic life. The placode sinks inwards to form the closed otic vesicle. By intricate infolding processes this vesicle is transformed into the membranous labyrinth as we know it in the adult anımal with its various compartments filled with endolymph and connected to each other by narrow passages ( $F_{1}$. 1). These compartments can be divided in two functionally different groups: one which is involved in the function of equilibrium (sacculus, utriculus and semicircular canals), the other involved in the perception of sound (the ductus cochlearis or scala media).

In all these compartments the epithelial lining derived from the original epithelium of the otic vesicle, is differentiated into areas with specialized sensory cells, associated with branches of the vestibular or acoustic nerves, and into areas where the cells are thought to be more or less involved in the secretory or resorptive processes of the labyrinthine fluids. In the adult stage the whole membranous labyrinth is encased in a bony capsule and is separated from the latter by a space filled with flud, the perilymph (Fig. 1)

This perilymphatic space originates from the disappearence of the mesenchymal tissue surrounding the membranous labyrinth during development In the cochlea, this fluid has the important function of transferring the sound waves for stimulation of the sensory cells of the 


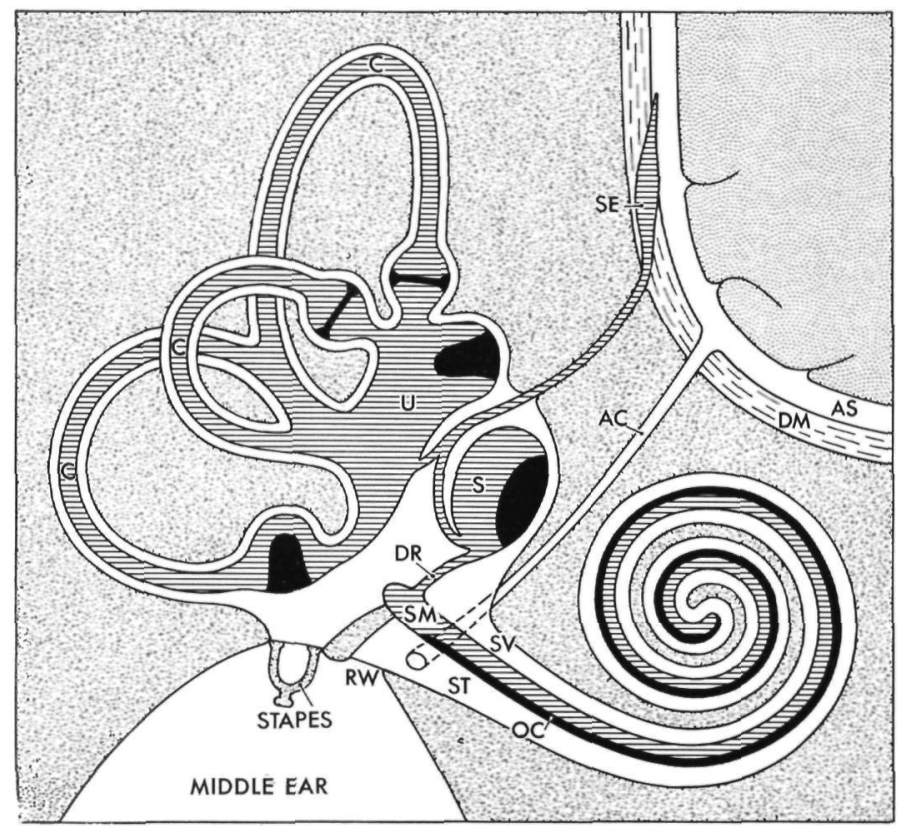

Fig. 1. Schematic drawing of the various compartments of the membranous labyrinth and its interconnections (redrawn and modified from von Ebner, 1903 and Bast and Anson, 1949). Black areas represent sensory cells. The spaces filled with endolymph are shaded and those filled with perilymph are white. AC: aqueductus cochleae, AS: arachnoid space, C: canales semicirculares, DM: dura mater, DR: ductus reuniens, OC: organ of Corti, RW: round window, S: sacculus, SE: saccus endolymphaticus, ST: scala tympani, SV: scala vestibuli, U: utriculus.

organ of Corti. The perilymphatic system is connected with the cerebrospinal fluid space by means of the aqueductus cochleae (Fig. 1). The endolymphatic space has a connection with the arachnoidal space by means of the saccus endolymphaticus, a closed sac situated in the dura mater and connected to sacculus and utriculus by the ductus endolymphaticus (Fig. 1).

Since this thesis is mainly concerned with the cochlear physiology only the cochlear structures will be described in detail. After a more extensive description of the mammalian cochlea, a short description of the avian cochlear duct will be given, as some of our experiments were carried out on the cochlear structures of one day old chickens.

\section{Anatomy of the mammalian cochlea}

The mammalian cochlea consists of a three-fold tube, spirally wound about a central bony axis, the modiolus (Fig. 2), which contains the main blood vessels and the main trunk of the acoustic nerve. The num- 
ber of turns varies from species to species. The cochlea of the guinea pig has $41 / 4$ turns.

The middle tube is called the ductus cochlearis or scala media, and is filled with endolymph. This scala ends at the apical turn and at the basal turn is connected with the sacculus by means of the very small ductus reuniens. The scala media, triangular in transverse section, is surrounded by spaces filled with perilymph on two sides: the scala vestibuli running up from the oval window to the apex, where it passes into the scala tympani running down to the round window (Fig. 1).

Fig. 2

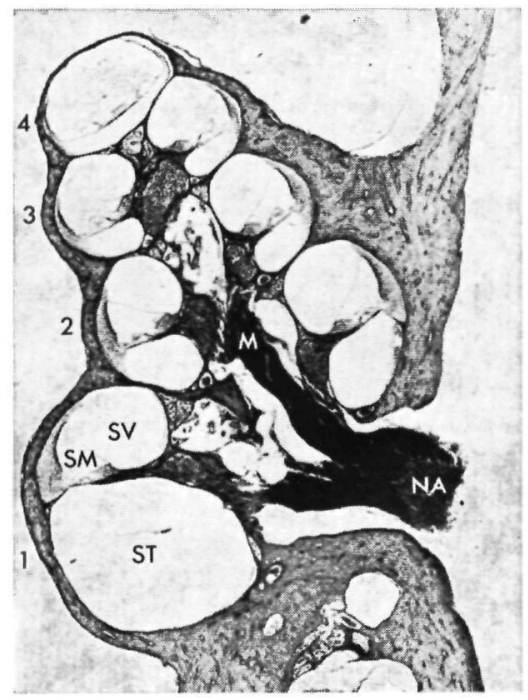

Fig. 3

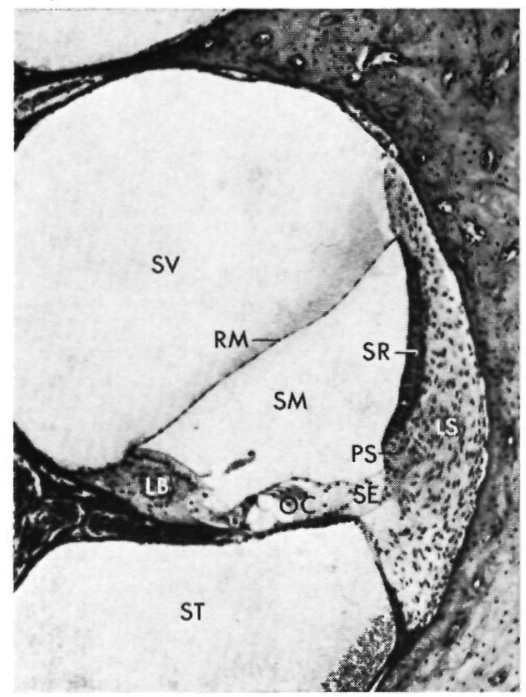

Fig. 2. Median section through the cochlea of the guinea pig (Hematoxylin-eosin, $\times 14)$.

Fig. 3. Transverse section through the scala media (Hematoxylin-eosin, $\times 50$ ). LB: limbus spiralis, LS: ligamentum spirale, OC: organ of Corti, PS: prominentia spiralis, RM: Reissner's membrane, SE: sulcus externus, SM: scala media, ST: scala tympani, SV: scala vestibuli, M: modiolus, NA: nervus acusticus, SR: stria vascularis. Arabic figures refer to the turn numbers.

The scala vestibuli and tympani are separated from neighbouring turns by a bony shelf which contains the arteries and veins supplying the lateral wall of the scala media. These vessels are connected with the main vessels in the modiolus. The separation between scala media and scala vestibuli is formed by Reissner's membrane. The membrana basilaris separates the scala media from the scala tympani. On its lateral side, the epithelium of the scala media rests on a layer of con nective tissue, the spiral ligament, which lies directly against the bone of the cochlear capsule. 
4. The lateral wall of the scala media

The major part of the epithelial lining of the lateral wall of the scala media is formed by the stria vascularis. A minor part is formed by the epithelium of the prominentia spiralis and sulcus externus ( $\left.F_{1 g} .3\right)$. The fine structure of the stria vascularis has been described by several authors (Smıth 1957, Rodriguez Echandia and Burgos, 1965. Rauch and Ruska, 1965. Hınojosa and Rodrıguez Echandıa, 1966; Spoendlın, 1967a).

It is a stratified epithelium consisting of three cell types with numerous capillaries embedded in it ( $\left.F_{1 g} 4\right)$. The marginal cells bordering the endolymphatic space have a rather smooth surface with a few short microvill and vesicular invaginations with a filamentous coating (Rodrıguez Echandia and Burgos, 1965) Near their free surface adjacent cells are firmly connected by junctional complexes, consisting of zonulae occludentes and further down by zonulae adhaerentes and desmosomes as classified by Farquhar and Palade (1963). The basal cell wall shows extensive infoldings so that the linear extent of the free surface is only $3 \%$ of the basal surface. These processes interdigitate with each other or with projections of the other cell types. only very small extracellular spaces of about $30 \mathrm{m \mu}$ width are seen between them (Rodriguez Echandia and Burgos, 1965). The cytoplasm of these infoldings is densely packed with mitochondria. Histochemical studies have revealed a very high concentration of enzymes participating in oxidative metabolism (Vosteen, 1961; Nakaı and Hılding, 1968a) and a high incorporation of protein and RNA precursors (Koburg. 1961; Koburg and Plester, 1962) in the stria vascularis. Microrespirometric studies (Chou and Rodgers 1962) revealed a $\mathrm{QO}_{2}$ for the stria vascularis even higher than that for kidney tissue. The cytoplasm in the apical part of the cell containing the nucleus shows only scattered mitochondria but is well furnished with free and membrane bound ribosomes, a Golgı complex and many vesicles, becoming more numerous and smaller towards the free surface Many of these vesicles are simılar in structure to the coated invaginations at the free surface of the cell. Such structures have been interpreted as a type of pinocytotic activity (Roth and Porter, 1964) but different from that in smooth muscle cells and endothelial cells.

The second layer is formed by the intermediate cells (Fig 4). These have large cytoplasmic processes running between those of the marginal cells or making contact with the underlaying basal cells. The cytoplasm contains only a sparse endoplasmatic reticulum and a few mitochondria The third type is formed by the basal cells, arranged in several firmly packed layers of flat cells connected to each other with desmosomes and zonulae occludentes (Spoendlın, 1967a). They gra- 


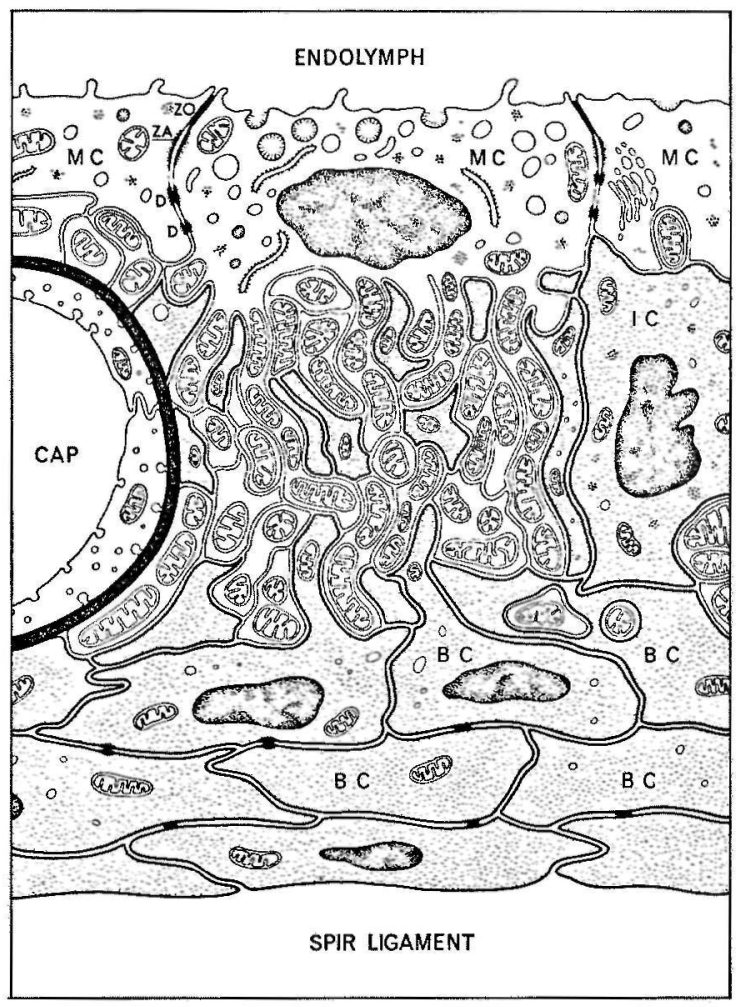

Fig. 4. Diagram of the stria vascularis (modified from Rodriguez Echandia and Burgos, 1965). The various cell types are indicated by MC (marginal cells), IC (intermediate cells and $\mathrm{BC}$ (basal cells). The marginal cells are connected to each other with a junctional complex consisting of a zonula occludens $(\mathrm{ZO})$, zonula adhaerens (ZA) and desmosomes (D). The apical surface shows pinocytotic activity and some microvilli, the basal cell membrane shows multiple infoldings, densely packed with mitochondria and interdigitating with those of the other cell types. Intermediate and basal cells contain only few cytoplasmatic inclusions. The basal cells are connected to each other with desmosomes and zonulae occludentes. All types of cells make contact with the basal lamina of the capillaries (CAP) whose endothelial cells show a high pinocytotic activity.

dually change into the cells of the spiral ligament without the intervention of a basal lamina. Some of the basal cells have projections interdigitating with intermediate and marginal cells. As in the intermediate cells the cytoplasm contains only a few organelles.

The numerous capillaries embedded in the epithelium are surrounded by a basal lamina adjacent to the endothelial cells which show many pinocytotic vesicles (Fig. 4). All types of cells make contact with this basal lamina, although extensions of the marginal cells are most frequent. 
The epithelium of the spiral prominence and sulcus externus forms a direct continuation of the stria vascularis $\left(F_{1 g} .3\right)$. It consists of only one cell layer separated from the spiral ligament by a distınct basal lamina. The epithelial cells of the prominence are cuboidal and possess a very irregular basal surface with numerous invaginations. The sulcus cells penetrate deeply into the spiral ligament. The free surface of the cells shows some microvilli. Adjacent cells are connected by zonulae occludentes near their free surface. The cytoplasm of the prominence cells contains a great amount of endoplasmatic reticulum, Golgı membranes and a few mitochondria. The sulcus cells, however, contain more mitochondria, vacuoles and only a very poorly developed endoplasmatic reticulum. In the spiral ligament behind this epithelium there are capillaries, irregular stroma cells and huge extracellular spaces penetrating into the epithelial invaginations. The stroma cells contain many mitochondria, vacuoles and a well developed endoplasmatic reticulum. Histochemical studies of this region revealed a high activity of several enzymes involved in the oxidative metabolism (Vosteen, 1961; Spoendlin and Balogh, 1963). Roots of the outer sulcus cells may penetrate deeply into this region, sometimes making contact with the stroma cells. and showing extensive membrane infolding associated with a great number of vacuoles (Spoendlın. 1967a; von Ilberg et al., 1968).

\section{The vestibular wall of the scala media}

The separation between endolymphatic space and scala vestıbuli is formed by the avascular membrane of Reissner. Its fine structure has been described by lurato (1967b); Duvall and Rhodes (1967a); von Ilberg (1968a). Reissner's membrane is composed of two cell layers: an outer layer of very flat cells, continuous with those lining the scala vestibulı (Duvall and Rhodes, 1967a) and an inner layer lining the endolymphatic space. The two cell layers are separated by a basal lamina, bordering the inner layer and a layer of intercellular substance (Fig. 5). Adjacent cells of the outer layer are not always attached to each other, so direct contact between the perilymph and the intercellular substance is present. The inner layer consists of cuboidal cells firmly connected to each other by a zonula occludens near the free surface. followed by a zonula adhaerens and desmosomes. The membrane facing the endolymph shows microvill and also invaginations with a coated surface (Iurato, 1967b). These invaginations are similar to those found on the free surface of the stria vascularis suggested to be associated with a special form of pinocytosis (Rodriguez Echandia and Burgos, 1965: Hinojosa and Rodriguez Echandia, 1966). Pinocytotic vesicles like those normally found in endothehal cells have also been shown on the side of the basal lamina (Iurato, 1967b; von Ilberg. 1968a). The basal and also the lateral cell walls behind the junctional complex show 


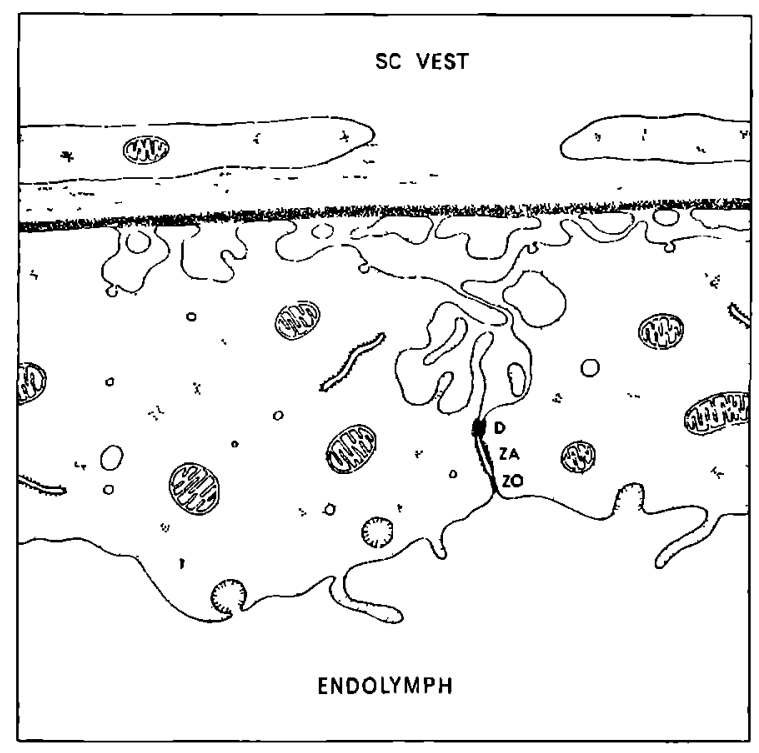

Fig. 5. Diagram of Reissner's membrane based on electron micrographs of Iurato (1957 b) and Duvall and Rhodes (1967 a). The epithelial cells on the endolymphatic side show microvill and pinocytotic activity on their free surface and are connected to each other with a junctional complex consisting of a zonula occludens ( $\mathrm{ZO}$ ), a zonula adhaerens (ZA) and a desmosome (D). The lateral and basal cell membrane show many infoldings and pinocytotic activity. The epithelial cells on the perilymphatic side, separated from those on the endolymphatic side by a basal lamina and intercellular substance, do not form a contınuous layer. Both types of cells contain only a few cytoplasmatic inclusions.

many irregular cell extensions making contact with the basal lamina or interdigitatıng with those of other cells. The cytoplasm of these cells contains a few mitochondria, some free and membrane bound ribosomes and vesicles of various sizes.

\section{The tympanal wall of the scala media}

The epithelial lining of the endolymphatic space on the side of the scala tympani consists of various types of cells (Engström et al., 1966; Iurato. $1967 \mathrm{a}, \mathrm{b})$. The major part is formed by the cells of the organ of Corti (Fig. 6). These cells, except for the hair cells, rest directly on the membrana basilaris. This membrane consists of a ground substance with numerous filaments embedded in it. On the perilymphatic side this membrane is covered with a layer of connective tissue cells resembling the outer layer of Reissner's membrane and the rest of the epithelial lining of the perilymphatic space. A small vessel is present in this 
membrane in the region of the hair cells, which is important for their nutrition (Kikuchi and Hilding, 1967).

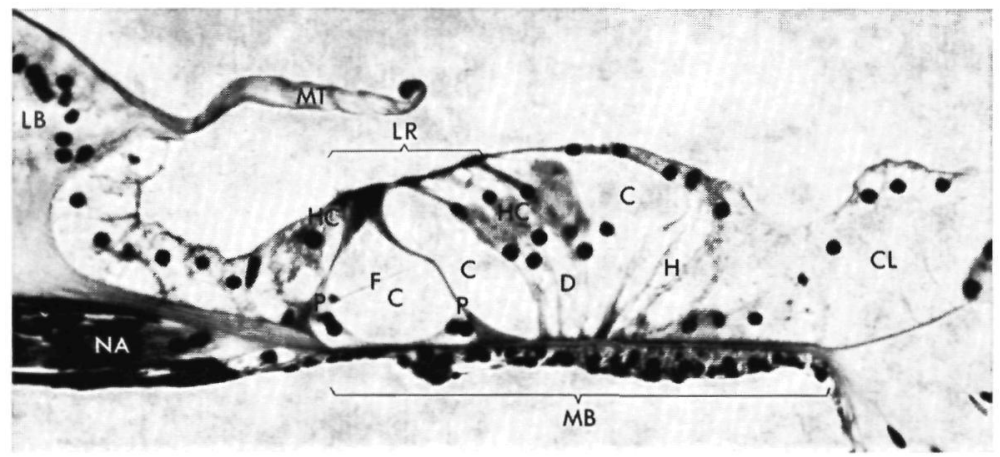

Fig. 6. The organ of Corti of the guinea pig (Hematoxylin-eosin, $\times 180$ ). C: cortilymph, CL: cells of Claudius, D: cells of Deiters, F: nerve fibres running to the hair cells, LB: limbus spiralis, LR: lamina reticularis, HC: hair cells, $\mathrm{H}$ : cells of Hensen, MT: membrana tectoria, MB: membrana basilaris, NA: nervus acusticus, P: pillar cells.

The cells of the organ of Corti can be distinguished in supporting cells with filaments (pillar cells and cells of Deiters) and those without filaments (cells of Hensen and Claudius) which pass into the cells of the sulcus externus. To the modiolar side the organ of Corti passes into the epithelium covering the limbus spiralis, a connective tissue structure resembling the ligamentum spirale. The membrana tectoria, composed of filaments embedded in an amorphous substance, is attached to the epithelium of the spiral limbus. The supporting cells have a rather clear cytoplasm with only a few organelles and vesicles. Moreover, the filamentous cells contain a great number of filaments running from the base to the apex, giving support to the hair cells. The adjacent cells are connected by zonulae occludentes alone in their apical part or followed by zonulae adhaerentes and desmosomes (Iurato, 1967b). The apical surface of the supporting cells shows many microvilli.

The highly differentiated sensory cells, divided into inner and outer hair cells, bear on their apical surface numerous hairs (stereocilia) which are in close contact with the membrana tectoria. The central axis of these hairs penetrates into the apical cytoplasm of the cells, consisting of a cuticular plate (lamina reticularis). Bending of the stereocilia caused by movements of the membrana basilaris, stimulates the hair cells and an action potential in the acoustic nerve is generated. Many mitochondria, vesicles and Golgi lamellae are found in the apical part 
of the cell A second concentration of mitochondria and vesicles is situated in the basal part, where synaptic contact is made with the nerve endings of the acoustic nerve Along the lateral surface a distinct layer of membrane structures and mitochondria are found. Histochemical studies revealed a high content of enzymes of oxidative and glycolytic metabolısm (Vosteen, 1961, Spoendlin and Balogh, 1963, Matschinsky and Thalmann, 1967) in the hair cells

Around the hair cells several large extracellular spaces continuous with each other can be observed These spaces which are traversed by the unmyelinated parts of the fibers of the acoustic nerve ( $\left.F_{1 g} 6\right)$, are filled with a flud called the cortilymph, thought to have the same ionic composition as perilymph

In view of its structural features, the scala media can be considered to be a closed sac filled with fluid The tight junctions between the cells bordering the endolymphatic space rule out an intercellular fluid transport as proposed by Farquhar and Palade (1963). From a morphological point of view the stria vascularis would be expected to play the most important role in cochlear cation transport. There is a great resemblance between the marginal cells of the stria vascularis and those found in epithelia shown to be involved in the active transport of ions, such as the dogfish rectal gland (Bulger, 1963) the salt gland of sea birds (Doyle, 1960, Komnick and Komnick 1963) and the kıdney tubules (Pease 1955) In the vestibular part of the labyrinth, areas with similar cells have been demonstrated (Dohlman, 1965. Nakai and Hilding, 1968b, Kimura 1969).

7. The ligamentum spirale and limbus spiralis

The ligamentum spirale and limbus spiralıs ( $F_{1 g s .} 2$ and 3 ) are composed of a very loose fibrillar connective tissue with large extracellular spaces (Iurato, 1967a) These spaces are especially large in the part of the ligamentum spirale bordering the scala tympani, where they may freely communicate with the perilymph (Spoendlin and Balogh, 1963). The fibrous bundles situated in the extracellular spaces form an irregular network in which the connective tissue cells are embedded In the adult stage most cells show a very poor cytoplasmatic content, except the layers bordering the scala vestibuli of both ligamentum spirale and limbus spiralis, and the cells behind the epithelium of the prominentia spiralis They contain many mitochondria, which is in agreement with histo-enzymological studies (Vosteen, 1961, Spoendlin and Balogh, 1963).

\section{Vascularisation}

The vascular supply of the membranous inner ear structures is derived from the arteria cochlearis, located in the modiolus (Axelsson, 1968) 
From this artery two main groups of vessels branch off the first group runs through the bony roof of the scala vestibuli and descends through the ligamentum spirale and the second group runs to the limbus spiralis and the organ of Corti. The first group gives off three groups of branches one above Reissner's membrane which supplies this part of the ligamentum spirale, a second provides the capillary network of the stria vascularıs and a third group supplies the prominentia spiralis. All these regions are drained by venules which descend to the collecting venules in the tympanal part of the ligamentum spirale, from whence they course through the floor of the scala tympan to the modiolar vein. The venous drainage of the organ of Cortı and limbus spiralis is also connected with the modiolar vein.

\section{Innervation}

The main part of the cochlear innervation is formed by the afferent and efferent nerve fibres of the acoustic nerve, supplying the sensory cells of the organ of Cortı and arising from the main nerve trunk in the modiolus (Figs. 2 and 6 ). These fibres lose their myelin sheath before they enter the cortilymph space. The innervation pattern of the hair cells has been described extensively by Smith and Sjostrand (1961) and Spoendlin (1967b. 1969) The adrenergic innervation consists of a dense perivascular network in the modiolus but these only accompany the vessels which course to the organ of Cort1 (Terrayama et al., 1966). Adrenergic fibres could not be demonstrated at all around the capillaries in the ligamentum spirale and stria vascularis. A second adrenergic system has been described, running along the cochlear nerve fibres to the organ of Cortı but never reaching the hair cells. This system forms a terminal plexus near the organ of Corti. where the fibres of the acoustic nerve lose their myelin sheath (Spoendlın and Lichtensteiner, 1966).

\section{Saccus endolymphaticus}

Because of its possible role in endolymph circulation this structure will be briefly described. The saccus is located within two separated layers of the dura mater and is connected with sacculus and utriculus by the ductus endolymphaticus $\left(F_{1} g .1\right)$. Because of its location it has also been suggested (Allen, 1964) that the endolymphatic sac, together with the aqueductus cochleae, represent, a mechanism protecting the inner ear from variations in liquor pressure. The submicroscopical structure has been extensively described by Lundquist (1965). The epithelium, one cell layer thick, rests on a loose connective tissue layer permeared by capillaries. Different cell types can be discerned, some of them showing considerable pinocytotic and phagocytotic activity The lumen of the sac is filled with many free floating macrophages and cell debris. 
11. Anatomy of the avian cochlea

Although there are no essential differences in the gross anatomy of the avian and mammalian labyrinth, the avian cochlea shows some remarkable characteristics (Amerlinck, 1923; Held, 1926; Schwartzkopf and Winter, 1960). The avian cochlear duct (scala media), surrounded by perilymphatic spaces, is a sac filled with endolymph, which is only

Fig. 7

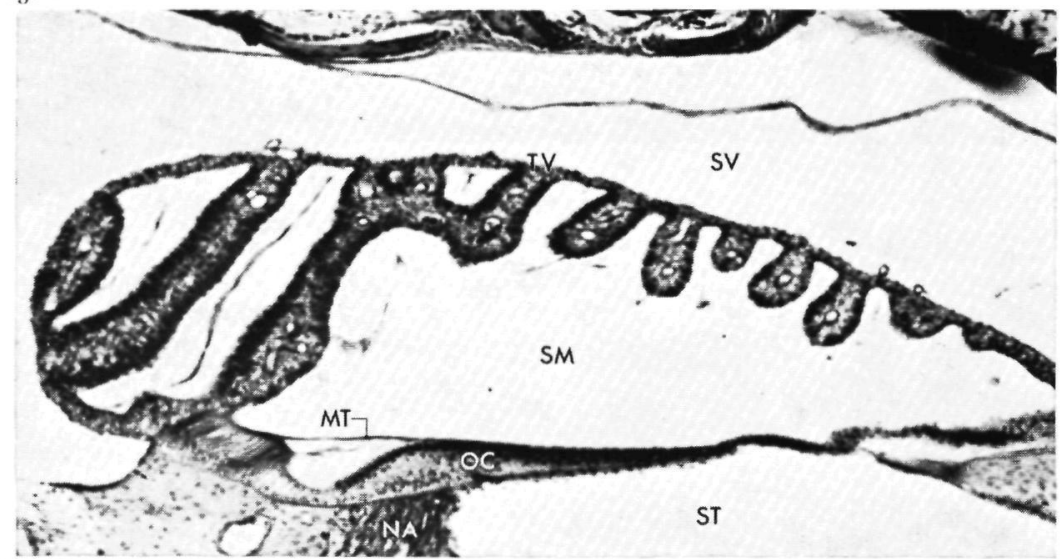

Fig. 8

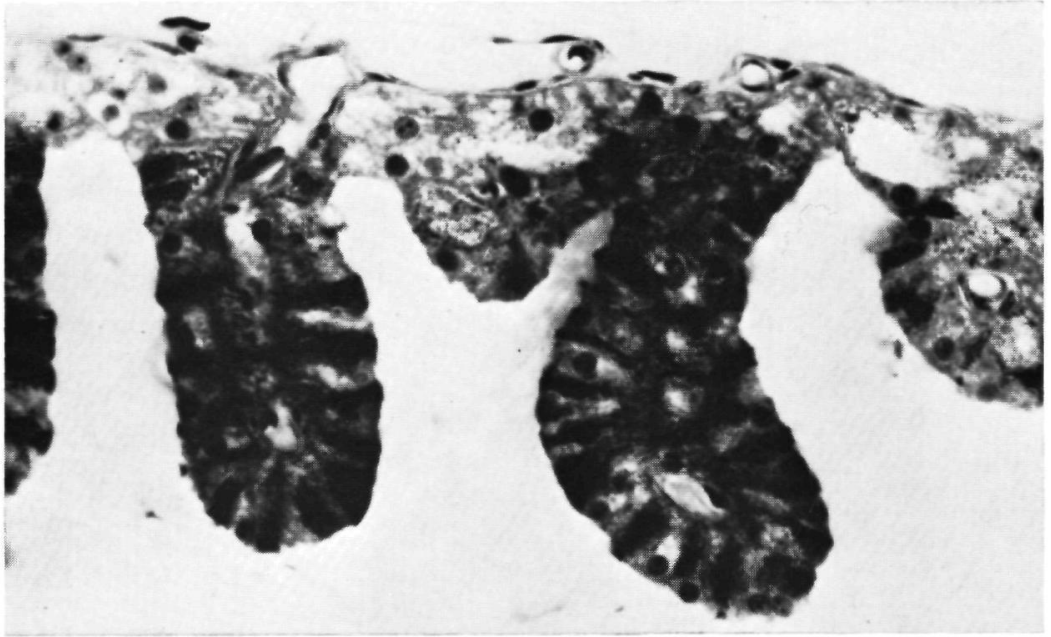

Fig. 7. Longitudinal section through the cochlea of the one day chicken (Iron-Hematoxylin, $\times 80$ ).

Fig. 8. Detail of the tegmentum vasculosum showing the epithelial lining of the endclymphatic space, consisting of dark and light cells (Heidenhain's Iron-hematoxylin, $\times 350)$. NA: nervus acusticus, MT: membrana tectoria, OC: organ of Corti, SM: scala media, ST: scala tympani, SV: scala vestibuli, TV: tegmentum vasculosum. 
slightly curved The epithelial lining of the scala media on the side of the scala tympani is formed by the sensory and supporting cells of the organ of Cortı, resting on the membrana basilarıs. The remaining part of the wall of the cochlear sac consists of the tegmentum vasculosum, a highly vascularised and richly folded epithelium with dark and light cells (Figs. 7 and 8 ). This structure may be considered phylogenetically to represent both Reissner's membrane and the stria vascularis of the mammalian cochlea

Recently an electronmicroscopical study of the tegmentum was reported (Jahnke et al., 1969). The basal cell membrane of the dark cells showed a great number of invaginations interdigitating with those formed by the light cells. The cytoplasm of the dark cells was densely packed with mitochondria while that of the light cells was very clear. 


\section{THE COCHLEAR FLUIDS}

\section{Introduction}

Besides a mechanical role in the transfer of sound vibrations from the middle ear to the organ of Corti, the inner ear fluids play an important role in providing the adaequate environment for the function of the sensory cells. Alterations in the ionic composition of these fluids may result in drastic effects on the cochlear potentials (Chapter III) and even lead to degeneration of the epithelial lining of the endolymphatic space (Duvall and Rhodes, 1967b; Duvall, 1968).

This chapter deals with the chemical composition of the cochlear fluids and with the possible role of different cochlear structures in their production and absorption.

\section{Composition}

Many studies of the composition and biophysical characteristics of the inner ear fluids have been carried out. The first determinations of the electrolyte content of the mammalian inner ear fluids have been reported by Smith et al. (1954). They demonstrated a characteristic difference in the ionic composition between peri- and endolymph. The $\mathrm{Na}^{+}$and $\mathrm{K}^{+}$content of the perilymph agreed with that of extracellular fluids, but the endolymph proved to be high in $\mathrm{K}^{+}$and low in $\mathrm{Na}^{+}$thus resembling an intracellular fluid. After this study many authors have reported results of the chemical analysis of cochlear fluids in various animal species. These results have been reviewed by Maggio (1966) and Fernandez (1967). Although there are variations in the reported data, it is consistently confirmed that both mammalian cochlear and vestibular endolymph contain a high $\mathrm{K}^{+}$and a low $\mathrm{Na}^{+}$concentration. Any variations, particularly in data on cochlear endolymph, may be the result of differences in techniques of collecting fluid samples. In view of the anatomical situation it is clear that endolymph samples may easıly be contaminated with traces of blood or perilymph. Moreover. come data have been derived from dead animals, which may result in a decrease of $\mathrm{K}^{+}$and an increase in $\mathrm{Na}^{+}$in the endolymph as shown by Rodgers and Chou (1966); Bosher and Warren (1968); Mendel- 
sohn and Konısh (1969). Therefore it seems likely that the most reIiable data are those which are low in $\mathrm{Na}^{+}$. In Table 1 data on the electrolyte composition of the inner ear fluids reported by various authors, have been summarised.

Table 1

COMPOSITION OF COCHLEAR FLUIDS *

\begin{tabular}{|c|c|c|c|c|c|c|c|}
\hline \multirow{2}{*}{ Species } & \multicolumn{3}{|c|}{ Endolymph } & \multicolumn{3}{|c|}{ Perilymph } & \multirow{2}{*}{ Reference } \\
\hline & $\mathrm{Na}^{+}$ & $\mathbf{K}^{+}$ & $\mathrm{Cl}^{-}$ & $\mathrm{Na}^{+}$ & $\mathrm{K}^{+}$ & $\mathrm{Cl}^{-}$ & \\
\hline Guinea pig (utriculus) & 26 & 142 & 110 & 148 & 5 & 120 & Citron and Exley (1957) \\
\hline Guinea pig (cochlea) & 2 & 151 & & 137 & 4 & & Johnstone et al (1963) \\
\hline Guinea pig (cochlea) & 1 & 154 & & 138 & 7 & & Bosher and Warren (1968) \\
\hline Guinea pig (cochlea) & 5 & 144 & & & & & Mendelsohn and Konishı (1969) \\
\hline Man (cochlea) & 13 & 144 & 114 & 139 & 4 & 118 & Rauch (1964) \\
\hline Cat (cochlea) & 30 & 173 & & 140 & 4 & & Silverstein (1966) \\
\hline
\end{tabular}

* All concentrations in mmole/l

3. Origin and circulation

Several microscopical and also some biochemical studies, dealing with the source and the circulation of cochlear fluds have been reported. In these studies various substances such as dyes, radioactive isotopes and particles of various origin were locally injected into the cochlear fluids, the cerebrospinal fluid or administered parenterally and were then traced with microscopical and chemical techniques. Results and conclusions have often been contradictory, which is presumably due to the techniques used, e.g. the use of dyes which may alter the membrane permeability or interfere with cellular metabolısm. Moreover, because the inner ear structures are very delicate they may easily be injured or even disrupted by local injections, as may be concluded from some experiments.

\section{a. Perilymph}

Because the perilymphatic space is connected with the cerebrospinal space by the aqueductus cochleae and by perivascular and perineural spaces, the question whether perilymph is derived from cerebrospinal fluid, has drawn much attention.

Various substances injected into the liquor cerebrospinalis have been shown to be transported to the perilymph (Arnvig, 1951; Altmann and Waltner, 1950, Hughes and Chou, 1963; Schuknecht and El Seif1, 
1963), indicating that the perilymph may be at least partially derived from the cerebrospinal fluid. However, occlusion of the aqueduct did not show histological or physiological alterations in the inner ear, suggesting that the cerebrospinal contribution is only a minor one (Schuknecht and El Seifi, 1963). This finding, together with differences in chemical composition, e.g. in protein content (Silverstein, 1966), and the swift appearance of parenterally administered radioisotopes in the perilymph (Rauch, 1964, Choo and Tabowitz, 1964), suggest that the perilymph is essentrally a blood ultrafiltrate from the capillaries in the scala vestibulı. It has been demonstrated that perilymph can more or less freely circulate through ligamentum spirale and limbus spiralıs from one scala to the other (Tonndorf et al., 1962; von Ilberg, 1968 b, c).

Absorption of perilymph has been shown to occur in the part of the ligamentum spirale bordering scala tympan by the perivascular tissue around the venules (Kirikae et al., 1961) and by the stroma cells in the region of the prominentia spiralis (von Ilberg et al., 1968).

\section{b. Endolymph}

Most studies on endolymph circulation deal with the function of the saccus endolymphatıcus ( $\mathrm{F}_{1 \mathrm{~g}}$. 1). Various substances injected into both cochlear (Guild, 1927; Lundquist, 1965; Ishis et al., 1966) and vestıbular endolymph (Do1, 1939; Dohlman and Ormerod, 1960) have been found to accumulate in the saccus lumen, being phagocytised or removed by pinocytosis. Silverstein (1966) was able to show that the fluid flow from the cannulated saccus stopped after occlusion of the ductus endolymphaticus. Kımura (1967) and Beal (1968) showed that prolonged occlusion of the ductus resulted in a hydrops of the cochlear duct, so confirming the flow direction and the absorptive or filtering function of the saccus. Because of the long distance it seems very likely that this structure is only involved in a long term absorption process to clear away cell debris and excess of flud from the endolymphatic system. Additional arguments in favour of this assumption are the low $\mathrm{K}^{+}$, high $\mathrm{Na}^{+}$and protein content of the saccus fluid (Silverstein. 1966) and the presence of acid phosphatase and proteolytic enzymes (Ishı et al., 1966).

However, several experiments have been reported indicating a local cochlear circulation which seems to be much more important in cochlear physiology. It has been demonstrated that a local intermixing of peri- and endolymph by rupturing Reissner's membrane only leads to a local disappearance of cochlear microphonic potential and a local degeneration of the epithelium (Lawrence et al., 1961; Schuknecht and El Seifi, 1963; Lawrence, 1966; Duvall and Rhodes, 1967 b; Duvall, 1968). A few mm from this tear the CMP was still present and the 
epithelium intact, suggesting a segmental metabolic independence of the cochlear structures.

Von Ilberg (1968 a,b) demonstrated that thorium dioxyde injected into the scala media was removed by pinocytotic activity of the stria vascularis and Reissner's membrane. Absorption of endolymph by the epithelium of spiral prominence and sulcus externus as shown by Yamamoto and Nakaı (1964), using ferrodextran, could not be confirmed by von Ilberg et al. (1968) Thorium dioxyde injected into perilymph could only reach the endolymph by pinocytosis of Reissner's membrane in the reverse direction (von llberg, 1968 a)

Naftalın and Harrison (1958) advanced the hypothesis that endolymph arises from perilymph passing through Reissner's membrane, while the stria vascularis extracts the excess $\mathrm{Na}^{+}$and pumps in $\mathrm{K}^{+}$to build up the required $\mathrm{K}^{+}$concentration against the leakage through Reissner's membrane. Support for this hypothesis can be derived from experiments with radioisotopes. Rauch (1964) showed that after intraperitoneal injection of $\mathrm{K}^{+2}$ the isotope concentration reached a much higher value in endolymph than in the blood or perilymph This was confirmed by Choo and Tabowitz (1965) after intracardiac injection of $\mathrm{K}^{42}$. These authors suggested a prominent role of the stria vascularis in $\mathrm{K}^{+}$transport from blood to endolymph. After intraperitoneal injection of $\mathrm{Na}^{22}$, the isotope concentration was consistently lower in endolymph than in perilymph. (Choo and Tabowitz, 1964; Rauch, 1964). Within two minutes after injection of $\mathrm{K}+2$ into the perilymph of the scala vestibul the isotope concentration in the endolymph became higher than in the perilymph, while the $K^{12}$ concentration of the stria vascularis was also very high. This transport could be partly inhibited by $\mathrm{NaCN}$, ouabain and rodoacetic acid. From these experiments Rauch $(1964,1966)$ concluded an active transport of $\mathrm{K} \pm 2$ from perilymph to endolymph through Reissner's membrane and a resorption through the stria vascularis.

The entrance of $\mathrm{Na} 22$ from the vestibular perilymph into the endolymph was much slower, reaching half of the perilymph isotope concentration after approximately seven minutes only (Rauch, 1964). The same author failed to show any significant entrance of $\mathrm{Na}^{+}$and $\mathrm{K}^{+}$ isotopes into the endolymph after injection into the perilymph of the scala tympanı. Borghesan (1957) suggested that from an anatomical point of view the spiral prominence may also take part in endolymph formation, supposing that this structure produces the "plasmatic" fraction while the stria vascularis produces the "crystalloid" fraction.

Many other cochlear structures have been thought to take part in endolymph secretion or absorption, however, without any experimental evidence. Nevertheless, in spite of the lack of direct experimental evidence, the morphology and metabolic activity of the stria vascularis 
suggest that this structure may play an important part in regulating the composition of cochlear endolymph The role of the other structures may only be a more or less passive one

\section{c. Cortulymph}

Although the exact composition of the flund surrounding the cells of the organ of Cortı (cortılymph) (Fig.6) is not known, this fluid may be considered as extracellular in composition, resembling perilymph. As suggested by Tasakı (1957) it is highly unlikely that this flund resembles endolymph, because unmyelinated fibres cannot function in a high $\mathrm{K}^{+}$medium Support for this statement is given by the experimental work of von Ilberg (1968 d) and Schuknecht and El Seifi (1963). showing that perilymph can freely pass the basilar membrane. Rauch (1964) was able to show that cortilymph is rich in $\mathrm{Na}^{+}$and poor in $\mathrm{K}^{+}$. Therefore it may be concluded that the barrier between per1lymph ( 1 e. cortilymph) and endolymph is formed by the lamina ret1cularis, the boundary of the cells of the organ of Corti to the endolymph. 


\section{ELECTRICAL PHENOMENA IN THE MAMMALIAN COCHLEA}

\section{Introduction}

Several electrical phenomena can be identified in the cochlea (Davis, 1957; Tasakı, 1957; Wever, 1966). They can be divided into resting DC polarisations and potentials that are generated after acoustic st1mulation. The group of resting potentials consists of the endolymphatic or endocochlear potential (ERP), representing an extracellular polarisation of the endolymph which is positive with respect to blood and perilymph, and the negative intracellular potentials of the epithelial cells lining the endolymphatic space.

To the second group belong the action potentials (AP), representing the sum of many spikes generated in the nerve fibres of the acoustic nerve: the cochlear microphonic potentials (CMP), an alternating current response to sound stumuli; and the summating potential (SP), representing a positive or negative change in the resting potential. In this chapter the literature dealing with the nature and origin of the CMP and the ERP will be reviewed. Because the action potential (AP) and the summating potential (SP) have not been studied by us, they will not be discussed.

\section{Endocochlear resting potential}

The endocochlear restıng potentıal (ERP), discovered by von Békésy in 1952, is an extracellular DC polarisation about $80 \mathrm{mV}$ positive with respect to the perilymph, blood or any inactive tissue of the head. This potential can be measured in the entire endolymphatic space of the mammalian cochlea. This large, positive potential is remarkable in two ways. Most body cells with their high internal $\mathrm{K}^{+}$concentration have a negative resting potential of the same magnitude, which is closely related to the $\mathrm{K}^{+}$concentration gradient between the intra- and extracellular compartments (Hodgkin and Keynes, 1955; Adrian, 1956) Thus, on the basis of the ionic composition of the endolymph, one would have expected a negative, rather than a positive ERP. The other remarkable point is that the vestibular parts of the endolymphatic system, having the same ionic composition as the cochlear endolymph 
(Table 1), have a resting potential of only a few millivolts (Smith et al., 1958, Schmidt, 1963 a). This potential has been shown to be independent of the cochlear resting potential (Schmidt, 1963 b).

Many experiments have been performed in order to demonstrate a dependence of the ERP on the ionic concentrations in peri- and endolymph. Introduction of a high $\mathrm{K}^{+}$solution in the endolymph depressed the ERP much less than injection of $\mathrm{Na}^{+}$-rich Ringer or perilymph (Tasakı et al., 1954; Davıs et al., 1955; Konıshı et al., 1966). Konıshı and Kelsey (1968 a) reported only a slight effect on the ERP after perfusing the scala tympanı with $\mathrm{Na}$-free Ringer. Tetrodotoxin, which blocks the sodium channel in nerve membrane (Loewenstem et al., 1963. Ozaki and Sato, 1965). did not show any effect on the ERP when introduced into the scala tympanı or scala media (Konishı and Kelsey, 1968 b). No effect could be demonstrated by injecting high $\mathrm{K}^{+}$ solution into the scala tympanı (Tasakı et al., 1954). Butler (1965), however, showed a decrease of about $50 \%$ in the ERP upon replacing the scala tympani perilymph with a solution containing $150 \mathrm{mM} \mathrm{K}$. Replacement of scala vestibulı perılymph with $\mathrm{K}^{+}$-rich $\mathrm{Ringer}$ had no effect on the ERP (Tasakı et al., 1954; Butler et al, 1962). Katsukı et al (1966) reported a 50\% decrease of the ERP after iontophoretic introduction of tetraethylammonium chloride into the scala media, suggesting the blockage of the $\mathrm{K}^{+}$channel (Hagiwara and Saito, 1959). However, no effect was found after introduction of this substance into the hair cell region From these findings it seems unlikely that the ERP represents merely a diffusion potential due to the ionic gradients between endo- and perilymph.

Several findings seem to support the assumption that the ERP is generated by the stria vascularis, a structure absent in the vestibular parts of the endolymphatic system. The ERP has been shown to be highly dependent on oxıdative metabolısm. A rapıd and sharp decrease can be found after reduction of the blood oxygen tension, caused by clamping the trachea, by inhalation of pure $\mathrm{N}_{2}$, or after local interruption of the cochlear blood supply (Konıshı et al., 1961). The same effect has been shown with local injection of $\mathrm{NaCN}$ (Davis et al., 1955: Konısh and Kelsey, 1968 c). Since the stria is the only cochlear epithelial structure which is richly vascularised and has a high oxidative metabolısm (Vosteen, 1961; Chou and Rodgers; 1962; Matchınsky and Thalmann, 1967) this structure seems very likely to be the generator of the ERP. Further support for this assumption has been supplied by Tasaki and Spyropoulos (1959). Moving an electrode along the epithelaal wall of the scala media, after removal of Reissner's membrane, they found the highest positive potential near the surface of the stria vascularis. The organ of Cort is excluded as a source of the ERP. because this potential is present in animals which lack the organ of 
Cort1 through hereditary or pathological causes (Davis et al., 1958; Tasakı and Spyropoulos, 1959).

A particularly intrigueing phenomenon is that prolonged anoxemia lowers the ERP beyond zero to negative values of $40-50 \mathrm{mV}$ within a few minutes, whereupon the potential gradually returns to zero in one or two hours (Konishı et al.. 1961). Measurements of the endolymphatic $\mathrm{K}^{+} / \mathrm{Na}^{+}$ratıo durıng anoxemia revealed no great changes in this ratio in the first minutes when the potential becomes negative, while the ratio dropped concurrently with the return of the negative potential to zero, suggesting that the negative potential represents an ionic diffusion potential (Johnstone, 1965).

Johnstone (1967) proposed that the ERP could be a $\mathrm{Na}^{+}$diffusion potential of a similar nature to that developed during the peak of an action potential in a nerve. This would require a permeability ratio of K.Na of 1:50. The negative potential arising after anoxemia was explained by assuming a change in this permeability ratio to $5: 1$, caused by lack of oxygen or accumulation of metabolites. According to Konıshı et al. (1967) and Konıshı and Kelsey (1968 c) this negative potential may represent a depolarisation potential of the cells of the organ of Corti. Alternatively Johnstone (1967) suggested that the positive potential could be generated directly by an electrogenic chloride and/or potassium pump

An active role of Reissner's membrane in the generation of the ERP has been proposed by von Ilberg and Imamura (1966). They reported that after perfusion of the scala vestibuli with oil the positive ERP was greatly and irreversibly decreased. Moreover, they demonstrated a potential difference generated by isolated pieces of Reissner's membrane, mounted in an Ussing chamber with normal Ringer solution on both sides. In two cases this potential could be affected by DNP, but not by ouabain.

Considering these findings no definitive conclusion can be drawn concerning the exact nature of the ERP. From the strong dependence of this potential on the oxidative metabolism the involvement of the stria vascularis in the maintenance of this potential seems highly likely.

\section{Intracellular DC polarisations}

The organ of Cortı (sensory and supporting cells) has consistently been reported to have a negative polarisation of about $50-80 \mathrm{mV}$ relative to the perılymph (von Békésy, 1952: Tasakı et al., 1954; Butler, 1965, Konısh and Kelsey, 1968 c). Only few data are avallable on the intracellular potentials of the epithelium lining the scala media. Von Békesy (1952) observed negative potentials of about $20 \mathrm{mV}$ relative to perilymph in Reissner's membrane and of $40 \mathrm{mV}$ in the supporting cells of the organ of Cortı. This latter finding has been confirmed by 
Lawrence (1967). The negative polarisation of the cells of the stria vascularıs (von Békésy, 1952) has not been confirmed by other authors. Tasakı et al. (1954) only measured positive potentials in this area. To explain the difference between their observations and those of von Békésy, they suggested that theır findıngs could be due to injury caused by the electrode, resulting in leakage of positive charge from the scala media. Butler (1965) demonstrated that the negative potential in the organ of Cortı decreased linearly with the $\mathrm{K}^{+}$concentration in the scala tympani, and he suggested that this potential is of extracellular origin. However this seems highly unlikely in view of the high permeability of the membrana basilaris and the extracellular ionic contents of the cortilymph (Chapter II, 3c). Konish1 and Kelsey (1968 a,b) showed no change in this potential after the introduction of tetrodotoxin or $\mathrm{Na}^{+}$free solutions into the scala tympanı. The effect of prolonged anoxemia was much slower than for the CMP and ERP, a decrease of only $40 \%$ being found after thirty minutes (Butler, 1965). A depressing effect of $\mathrm{NaCN}$ introduced into the scala tympani on this potential has also been described (Konishi and Kelsey, $1968 \mathrm{c}$ ).

In spite of the few data reported on the DC polarisations of the epithelium lining the endolymphatic space, the cell interior is most likely negatively charged with respect to the outer side. As for the cells of the organ of Corti it seems confirmed that this potential is mainly built up by the $\mathrm{K}^{+}$gradient across the cell membrane, as has been demonstrated in many other cells.

\section{Cochlear microphonic potential}

The cochlear microphonic potential (CMP) is an alternating electrical potential which at low and moderate sound intensities accurately and without measurable phase difference reflects the displacement of the basilar membrane or more exactly the displacement of the hair-bearing ends of the hair cells (lamina reticularis) relative to the membrana tectoria (von Békesy, 1960, Davis, 1957, 1961). There is no true threshold and no refractory period up to frequencies of $100 \mathrm{kc}$. The CMP can be measured on the outer side of the cochlea (e.g. at the round window) but also, and with greater amplitude, in the cochlear structures and fluds. The CMP for both low and high frequencies can be derived from the basal turns, in the apical turns only responses to low frequencies can be found (Tasaki et al., 1952). This agrees with the mechanical movement of the basilar membrane (von Bekesy, 1960). The CMP, like the positive ERP, has been shown to be highly dependent on oxıdative metabolısm (Misrahy et al., 1958 a; Konıshı et al., 1961; Rice and Shinaberger, 1961; Chambers and Lucchina, 1966; Konısh and Kelsey, $1968 \mathrm{c}$ ), although an anoxemic fraction of about $10 \%$ persists for hours after death (Davis, 1957). 
Upon moving an electrode from the scala tympanı through the basilar membrane to the scala vestibuli, the amplitude of the CMP was strongly enhanced in the region of the organ of Cortı, sometimes reaching a maximum of a few $\mathrm{mV}$ (Tasakı, 1957). Upon entering the scala media, the phase of the CMP suddenly reversed, without change in the amplitude. During further penetration into the scala media no changes were observed. After penetration of Reissner's membrane the amplitude immediately decreased, without change in the phase however. These findings strongly suggest that the CMP is generated at or near the lamina reticularis. Davis. $(1957,1961)$ concluded that it represents a current flow across the hair bearing surface of the hair cells, as the membrane resistance changes with deflection of the hairs of the hair cells. This current was suggested to be driven by the ERP and the negative DC polarisation of the hair cells.

Additional support for this assumption can be derived from several experiments. A DC polarising current, with the positive pole in the scala media or vestibuli and the negative pole in the scala tympani, increased the amplitude of the CMP. A current flowing in the reverse direction dimınıshed the amplitude (Tasakı and Fernandez, 1952; Tasakı et al., 1954; Konıshi and Yasuno, 1963). Application of hydrostatic pressure to the various cochlear compartments showed that moving the organ of Cort to the scala vestibuli reduced the ERP and moving it to the scala tympanı increased that potentıal (Tasakı et al., 1954). These effects are presumably due to a decrease and increase of the leakage current from scala media to scala tympanı (Johnstone and Johnstone, 1966). Moreover, Johnstone et al. (1966) showed a decrease of the effective resistance of the scala media from a loud sound resulting in a voltage drop of $6 \mathrm{mV}$.

In addition the CMP, like the positive ERP, was depressed, when endolymph was replaced by a $\mathrm{K}^{+}$-poor solution (Konishı et al., 1966). On replacement of scala vestibuli perilymph with $\mathrm{K}^{+}$-rich solutions no clear effect on the CMP could be found. However, when a $\mathrm{K}^{+}$-rich solution was introduced into the scala tympanı CMP was strongly depressed (Tasakı and Fernández, 1952; Tasakı et al., 1954, Butler et al., 1962). From the lack of an effect on the CMP of replacing scala tympanı perilymph with $\mathrm{Na}^{+}$-free solution or a solution containing tetrodotoxin. Konishı and Kelsey (1968 a, $1968 \mathrm{~b}$ ) concluded that this potential is dependent on the high $\mathrm{K}^{+}$concentration in the endolymph The lack of effect of tetrodotoxin has been confirmed by Katsukı et al. (1966), using an ıntophoretical technique. Butler (1965) demonstrated that the decline of the CMP after anoxemia closely follows that of the algebraic sum of ERP and the negative potential of the organ of Corti, 1.e the DC gradient across the lamina reticularis, suggesting that the CMP represents a modulation of both resting potentials. 
The involvement of an active cation pump in the generation of the CMP has recently been suggested by Matsuura et al (1968) He found that the CMP recorded from the hair cells of the saccular macula of the goldfish was inhibited by ouabain applied to the perilymphatic side but not to the endolymphatic side. Application of a solution containing $120 \mathrm{mM} \mathrm{K}^{+}$showed the same effect.

From the reported data it may be concluded that the existence of the CMP is highly dependent on the presence of the ERP and the negative DC polarisation of the hair cells. In addition many experiments are in favour of the hypothesis that the CMP would represent an alternating current, governed by changes in the resistance of the lamina reticularis.

5. Electrical phenomena in the avian cochlea

The same potentials demonstrated in the mammalian cochlea have been observed in the cochlea of birds, although they are smaller in magnitude (Schmidt and Fernández, 1962).

The ERP of about $20 \mathrm{mV}$ in the avian cochlea appeared to be highly sensitive to anoxia and higher than the resting potentials in the labyrinthine parts of the endolymphatıc system, as has also been demonstrated in mammals (Smith et al., 1958). The labyrinthine potentials have been shown to be independent of the cochlear resting potential (Schmidt. 1963 b).

In view of these findings it may be concluded that no essential differences seem to exist between the electrical phenomena in the mammalian and the avian cochlea. 


\section{CATION TRANSPORT AND THE $\mathrm{Na}^{+}{ }^{-} \mathrm{K}^{+}$-ATPase SYSTEM}

\section{Introduction}

It has now been widely accepted that the maintenance of the high $\mathrm{K}^{+}$ and low $\mathrm{Na}^{+}$concentrations in most animal cells, against the reverse concentrations in the extracellular medium, depends on a cation pump or transport system. This system moves cations through cell membranes against their electrochemical gradients, which process is defined as active transport (Ussing, 1949). Since active transport is an energyrequiring process, it appeared likely that ATP provides the energy for this process. Definitive proof was supplied by experiments in which ATP was introduced into resealed erythrocyte ghosts (Gárdos, 1954) and into the squid grant axon (Caldwell et al., 1960). This explains the inhibition of active cation transport by inhibitors of energy metabolism

In addition active cation transport can be specifically inhibited by cardiac glycosides, as first shown by Schatzmann (1953) in erythrocytes. In 1957 Skou reported that particles from crab nerve homogenates contained a $\mathrm{Mg}^{2+}$ activated ATPase activity, which could be increased by the simultaneous addition of $\mathrm{Na}^{+}$and $\mathrm{K}^{+}$ions. The increased activity could be inhibited by cardiac glycosides (Skou, 1960). These findings led him to suggest that this $\mathrm{Na}^{+} \mathrm{K}^{-}$activated ATPase ( $\mathrm{Na}^{+}-\mathrm{K}^{+}-\mathrm{ATP}$ ase) activity might be involved in active cation transport across the cell membrane. Subsequently, the $\mathrm{Na}^{+} \mathrm{K}^{+}-\mathrm{AT}$ Pase system has been demonstrated in a great variety of tissues and shown to be intimately connected with active cation transport in many biological systems.

2. Distribution of the $\mathrm{Na}^{+}-\mathrm{K}^{\perp}-\mathrm{ATP}$ ase system and correlation with cation transport

The discovery of the $\mathrm{Na}^{+}-\mathrm{K}^{+}-\mathrm{ATP}$ ase activity in crab nerve membranes has been followed by a great number of publications demonstrating the presence of this enzyme system in a great variety of tissues from various anımal species, including invertebrates, and recently it has even been demonstrated in bacteria (Hafkenscheid and Bonting, $1968,1969)$. 
Post et al. (1960) and Dunham and Glynn (1961) showed the presence of this enzyme system in erythrocyte membranes. Moreover, it appeared from experiments with resealed erythrocyte ghosts that the properties of the enzyme system were in good agreement with the properties of the cation transport system (Dunham and Glynn, 1961; Post et al., 1960; Whittam, 1962).

In a systematic study on the cat Bonting et al. (1961 a) showed the $\mathrm{Na}^{+}-\mathrm{K}^{+}-\mathrm{ATPase}$ activity present in nearly all tissues. It was only absent in noncellular tissues or tissues with low cell density. The highest activities have been shown in tissues with a secretory function such as choriold plexus (Vates et al., 1964), rectal gland of elasmobranchs (Bonting, 1966), nasal gland of marine-birds (Bonting et al , 1964 a), kidney (Bonting et al., 1961 a, 1962) or in tissues involved in excitatory processes such as nerve (Jarnefelt, 1961), brain (Bonting et al., $1961 \mathrm{a}, 1962$ ), retina (Bontıng et al., 1964 c) and electroplax (Bontıng et al., $1961 \mathrm{~b}$ ). In another report Bontıng and Caravaggıo (1963) demonstrated a close quantitative correlation between the $\mathrm{Na}^{+}-\mathrm{K}^{+}$-ATPase activity and the cation fluxes in a variety of tissues. calculating an average cation/ATP ratio of 3 .

Tosteson et al. (1960) and Baker and Simmonds (1966) were able to show that the erythrocytes of certain varieties of sheep and opossum with a high content of potassium show a much higher $\mathrm{Na}^{+}-\mathrm{K}^{-}$-ATPase activity than those with a low concentration of potassium. Wiley (1969) demonstrated that erythrocytes from patients with hereditary spherocytosis, show a high sodium leak into the cell which was accompanied by an enhanced $\mathrm{Na}^{+}-\mathrm{K}^{+}-\mathrm{ATPase}$ activity. When ducks were transferred from a fresh water to a salt water diet, an increase was observed in the $\mathrm{Na}^{+}-\mathrm{K}^{+}-\mathrm{ATPase}$ activity of the nasal gland, which serves as an extrarenal $\mathrm{Na}^{+}$-secretory system (Fletcher et al., 1967). In the developing brain a parallel increase has been found between $\mathrm{Na}^{+}-\mathrm{K}^{+}$-ATPase and neural actıvity (Bıgnamı et al., 1966; Abdel-Latıf et al., 1967). These examples clearly show the role of the $\mathrm{Na}^{+}-\mathrm{K}^{+}-$ ATPase system in active cation transport.

The localisation of the enzyme activity in the cell membrane, a prerequisite for its physiological role, has been confirmed by various authors: nervous tissue (Bonting et al., 1962; Cummins and Hyden, 1962), erythrocytes (Post et al., 1960; Dunham and Glynn, 1961). liver (Bonting et al., 1962; Emmelot and Bos, 1966), kıdney (Landon and Norris, 1963), muscle (Portıus and Repke, 1967), intestıne (Berg and Chapman, 1965, Rosenberg and Rosenberg, 1968).

\section{Properties of the $\mathrm{Na}^{+}-\mathrm{K}^{+}-\mathrm{ATP}$ ase system}

The enzyme system requires for activation $\mathrm{Na}^{+}$and $\mathrm{K}^{+}$together, in addition to $\mathrm{Mg}^{2+}$. $\mathrm{K}^{+}$can be replaced by $\mathrm{NH}_{4}{ }^{+}, \mathrm{Rb}^{+}$and $\mathrm{Cs}^{+}$. Although 
there are slight differences in the concentrations of $\mathrm{Na}^{+}$and $\mathrm{K}^{+}$giving half maximal activity in various tissues, activation by $\mathrm{K}^{+}$in the presence of $\mathrm{Na}^{+}$occurs at much lower concentrations than by $\mathrm{Na}^{+}$in the presence of $\mathrm{K}^{+}$(Skou, 1957; Post et al., 1960, Bonting et al., 1964 a; Bonting, 1966; Bakkeren and Bonting, 1968). From experıments with erythrocyte ghosts (Post et al., 1960; Dunham and Glynn, 1961; Whittam, 1962; Garrahan and Glynn, $1967 \mathrm{a}, \mathrm{b}$ ) and nerve axons (Baker. 1963. Baker and Connelly, 1966, Baker et al., 1969) it has been shown that $\mathrm{K}^{+}$activates on the outside of the membrane and $\mathrm{Na}^{+}$on the inside of the membrane. A high concentration of $\mathrm{K}^{+}$on the inner side can compete with $\mathrm{Na}^{+}$and inhibit transport.

The only substrate that can be utilised is ATP, with UTP. ITP and GTP little or no activity could be found (Skou, 1960; Post et al., 1960). The $\mathrm{pH}$ optıma for $\mathrm{Na}^{+}-\mathrm{K}^{+}$-ATPase activities from various tissues may vary slightly $(7.0-7.5)$ but they are very $d_{1}$ fferent from those of the glycoside-insensitive residual $\mathrm{Mg}^{2+}$-ATPase, which range from 8.4-8.9 (Skou, 1960: Taylor, 1962, Bontung et al., 1964a: Bonting. 1966; Rosenberg and Rosenberg, 1968; Ridderstap and Bonting, 1969 a, b) .

The $\mathrm{Na}^{+}-\mathrm{K}^{+}-$ATPase activity is specifically inhibited by cardiac glycosides. Although the sensitivity of the enzyme system in various tissues and animal species may vary, there is a striking resemblance between enzyme and transport system in relation to inhibition by cardiac glycosides (Post et al., 1960; Vates et al., 1964; Ridderstap and Bonting, $1969 \mathrm{a}, \mathrm{b})$. The inhibitory effect of cardiac glycosides in both systems at partially inhibitory concentrations may be antagonised by rasing the $\mathrm{K}^{+}$concentration (Dunham and Glynn, 1961; Bonting et al . 1963; Judah and Ahmed, 1964). A stımulatory effect of cardiac glycosides at very low concentrations has been demonstrated for the enzyme activity (Bonting et al., 1964 a; Bonting, 1966; Vates et al., 1964; Palmer et al., 1966), and this biphasic effect has also been shown in transport inhibition (Palmer and Nechay, 1964; Oppelt and Palmer. 1966: Ridderstap and Bontıng, 1969 b). Although chemically different from the digitalis substances, erythrophleum alkaloıds are also strongly inhibitory to $\mathrm{Na}^{+}-\mathrm{K}^{+}-\mathrm{ATP}$ ase and cation transport (Bonting et al., 1964 b; Vates et al., 1964; Ridderstap and Bontıng, 1969 b). Low concentrations of $\mathrm{Ca}^{2+}$ inhibit enzyme activity and cation transport (Skou, 1957; Hoffman, 1962) presumably by the formation of a $\mathrm{Ca}^{2+}+$ ATP complex which may be competitive with the $\mathrm{Mg}^{2+}-\mathrm{ATP}$ substrate complex (Epstein and Whittam, 1966).

From these observations it may be concluded that de $\mathrm{Na}^{+}-\mathrm{K}^{+}$ATPase activity in a great variety of tissues represents the same enzyme system. 
4. Function of the $\mathrm{Na}^{+}-\mathrm{K}^{+}-\mathrm{ATP}$ ase system

The primary function of the cation pump is to maintain the ionic concentration gradients between intra- and extracellular compartments necessary for cell metabolism and prevention of swelling of the cell. In addition the cation pump plays a central role in other processes. In excitatory tissues such as nerves and muscles, it maintains and restores the ionic gradients after depolarisation.

The enzyme system has also been shown to play an important role in secretory processes which depend on an active $\mathrm{Na}^{+}$transport, such as the formation of aqueous humor (Bonting and Becker, 1964), cerebrospinal fluid (Vates et al., 1964) pancreatic juice (Ridderstap and Bonting, 1969 a, b) and in sweat secretion (Slegers, 1968). In the nasal gland of marine birds (Bonting et al., 1964 a, Fletcher et al., 1967) and salt gland of elasmobranchs (Bonting, 1966) it is involved in removal of excess $\mathrm{Na}^{+}$from the blood. It also functions in the reabsorption of $\mathrm{Na}^{+}$in kıdney (Palmer and Nechay, 1964; Katz and Epsteın, 1967) and toad bladder (Bonting and Canady, 1964).

In addition, many instances have been found, where the transport of nonelectrolytes is coupled to the function of the cation pump (Crane, 1965); Rosenberg et al , 1965, Newey et al, 1968).

5. Mechanism of the $\mathrm{Na}^{+}-\mathrm{K}^{+}-\mathrm{ATPase}$ system

A number of experiments during the past ten years have demonstrated that the hydrolysis of ATP by the $\mathrm{Na}^{+}-\mathrm{K}^{+}$-ATPase system does not occur in a single step. Skou (1960) showed that a membrane fraction, containing $\mathrm{Na}^{+}-\mathrm{K}^{+}$-ATPase activity, could also catalyze an ATP-ADP exchange reaction, suggesting the formation of a phosphorylated intermediate. The use of ${ }^{2} \mathrm{P}$-labelled ATP as substrate for membrane fragments revealed that this ATP-ADP exchange was activated in the presence of $\mathrm{Mg}^{2+}$ and $\mathrm{Na}^{+}$and that the phosphate group was transferred to some intermediate in the membrane (Albers et al, 1963; Charnock and Post, 1963; Heinz and Hoffman, 1965). This suggests that the first step consists of a $\mathrm{Na}^{+}-\mathrm{Mg}^{2+}$ activated transfer of an energy-rich phosphate to the enzyme system. Upon contact with $\mathrm{K}^{+}$ this phosphate group is released as inorganic phosphate into the cell interior (Bader et al , 1968; Fahn et al.. 1968), representing the second step This second step can be inhibited by very low concentrations of cardiac glycosides (Post et al, 1965, Ahmed and Judah, 1965), while the $\mathrm{Na}^{+}$dependent phosphorylation is only inhibited at very high concentrations of cardiac glycosides. The $\mathrm{K}^{+}$-activated dephosphorylation step is supposed to be intimately related to the glycoside sensitive $\mathrm{K}^{+}$-phosphatase activity observed in various tissues (Albers and Koval, 1966; Bader and Sen, 1966; Bakkeren, 1968). 
Our knowledge of the structure of this enzyme system is still very limited, because it has not been solubilised and therefore the normal techniques of structural analysis of proteins cannot be applied. Some models for the system have been proposed. Opit and Charnock (1965) suggested that the enzyme system has a peptide back bone, which has many negatively charged sites capable of binding $\mathrm{Na}^{+}$and $\mathrm{K}^{+}$as counter ions. When the internal $\mathrm{Na}^{+}$concentration is high, most negative sites will be occupied by $\mathrm{Na}^{+}$, resulting in a phosphorylation of the enzyme system by ATP. This would cause the peptide chain to elongate slightly and to rotate in an outward direction between two adjacent phosphorylation sites. The $\mathrm{Na}^{+}$-carrying sites are now positioned outwardly and $\mathrm{Na}^{+}$is exchanged for $\mathrm{K}^{+}$followed by dephosphorylation and backward rotation of the membrane. A somewhat similar model has been proposed by Albers and coworkers (1968), assuming that the enzyme system may transform from a "cis" into a "trans" form In the "cis" form the cation binding sites are oriented to the cell interior. Excess of $\mathrm{Na}^{+}$1ons activates the transphosphorylation, and the enzyme is transformed into the "trans" form and the binding sites oriented to the outside, transporting $\mathrm{Na}^{+}$to the outside of the membrane. In the presence of $\mathrm{K}^{+}, \mathrm{Na}^{+}$is exchanged for $\mathrm{K}^{+}$and dephosphorylation takes place. The "trans" form then returns to the "cis" form, transporting $\mathrm{K}^{+}$ions into the cell.

\section{Purpose of this investigation}

The purpose of this investigation was to determine whether the cation gradients existing between peri- and endolymph, or blood and endolymph, are maintained by the $\mathrm{Na}^{+}-\mathrm{K}^{+}$-activated ATPase system, which has been shown to play an essential role in maintaining the cationic gradients in a great number of tissues.

The first object was to locate the site of the cation pump system. Since a reliable histochemical method for the demonstration of $\mathrm{Na}^{-}-\mathrm{K}^{+}$ATPase activity is still lacking, we have obtained the quantitative distribution of the enzyme activity in the cochlea by using microdissection and ultra-micro enzyme assay techniques.

The second object was to demonstrate a relationship between the cochlear potentials and the functioning of the $\mathrm{Na}^{+}-\mathrm{K}^{+}-$ATPase system. For this purpose we made use of the specific inhibitory effect of ouabain on the $\mathrm{Na}^{+}-\mathrm{K}^{+}$-ATPase activity by perfusing this substance through the inner ear of the anaesthetısed anımal and simultaneously measuring its effect on the potentials.

Finally a number of experiments were carried out to elucidate the nature of the large, positive endolymphatic resting potential. 


\section{MATERIALS AND METHODS}

\section{Materials}

The following chemicals and materials were used: adenosinetriphosphate, disodium salt (1); ethylenediamine-tetra-acetate, disodium salt (2): tris- (hydroxymethyl)-aminomethane (2); erythrophleine sulphate (2); ouabain (3); tris-adenosinetriphosphate (4); acetazolamide (5); lactic acid (6);

1. C. F. Boehringer und Soehne G.m.b.H., Mannheim, Germany.

2. E. Merck A.G., Darmstadt, Germany.

3. Nutritional Biochemicals Corporation, Cleveland, Ohio, U.S.A.

4. Sigma Chemical Company. St. Louis, Missouri, U.S.A.

5. American Cyanamid Company, Pearl River, New York, U.S.A.

6. The British Drug Houses Ltd., Poole, England.

2. Biochemical assays

a. Animals

Apart from the use of one day old chicken for ATPase assays, all further experiments have been carried out on guinea pigs.

For both biochemical and electrophysiological experiments young adult guinea pigs of a pigmented strain were used $250-350 \mathrm{~g}$ body weight). In the pigmented animals the stria vascularis is pigmented, facilitating its recognition and separation from the other inner ear structures for enzyme assay. Moreover, in most animals this band of pigmented cells, marking the lateral wall of the scala media, is visible through the bony cochlear wall, indicating the right place to pierce a microelectrode into the endolymphatic space.

\section{b. Tissue preparation}

For the enzyme assays the inner ear structures of one day old chickens and of guinea pigs were dissected within 45 minutes after death. Immediately after decapitation a piece of tissue containing the inner ear was separated from the skull and brought to $0^{\circ} \mathrm{C}$. All further dissection procedures were carried out at $0^{\circ} \mathrm{C}$. with the aid of a Zeiss stereomicroscope. 


\section{Chicken}

In order to isolate the membranous inner ear of the one day old chicken a transverse section was made through the head in the otic region. The inner ear, extending from the middle ear to the middle of the base of the skull, could be recognised by its hyalıne cartılagınous capsule. With a small piece of razor blade this capsule was carefully cut away until the membranous cochlear sac became exposed. After sectioning the acoustic nerve the whole sac could be lifted out of its capsule with fine forceps. For isolation of the tegmentum vasculosum the whole cochlear sac was placed on a glass slide and with a fine hair, mounted in glass, this lobulated structure could be separated from the rest. Because of the high viscosity of the avian endolymph, due to a high mucopolysaccharide content (Dohlman and Ormerod, 1960), a variable amount of this fluid could not be removed and adhered to the tegmentum vasculosum. This will result in a variable reduction of the true enzyme activity, based on tissue dry weight

\section{Guınea pig}

After decapitation the whole temporal bone of the guinea pig was dissected The wall of the middle ear was removed to give wide exposure of the cochlea, protruding into the middle ear cavity ( $F_{1 g} 9$ ). Afterwards the bony cochlear capsule was carefully chipped away and the membranous inner ear became visible. With the use of a small hook and fine forceps, a piece of tissue consisting of ligamentum spirale and stria vascularis was loosened and dissected turn by turn proceding from apex to base. After stretching this tissue on a glass slide, the pigmented stria vascularis could be scraped from the underlying spiral ligament with the use of a hair mounted in a holder. In order to study the distribution of enzyme activity in the various parts of the ligamentum spirale, this structure was divided longitudinally into three parts with the aid of a piece of razor blade part $A$ behind the stria vascularis and bordering the scala vestibuli, part $B$ in the region of the prominentia spiralis and sulcus externus and part $C$ bordering the scala tympanı ( $F_{1 g} 23$ ). After dissection, all tissues were frozen on dry ice in small glass tubes, lyophilised for several hours in tubes with silicagel at $-25^{\circ} \mathrm{C}$ and stored in vacuo at the same temperature until used No significant loss of activity was noted over periods of storage up to four weeks. For the isolation of Reissner's membrane and the organ of Corti another method had to be used because these structures could only rarely be distinguished in the fresh inner ear.

Dissection of these structures was possible after lyophilising the whole cochlea. The cochlea was freed from adhering bone without damaging the bony cochlear capsule. Both oval and round windows 


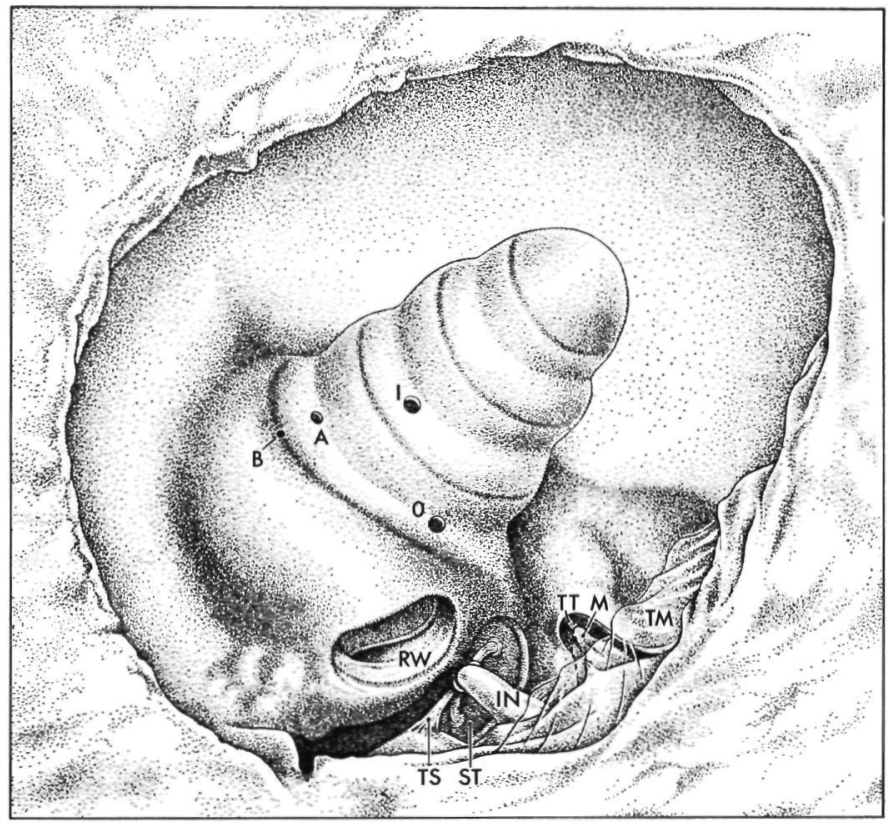

Fig. 9. Drawing of the position in the guinea pig middle ear of the cochlea. The cochlea was exposed by removal of part of the bony wall of the middle ear and of the main part of the tympanic membrane to obtain a better view of the windows. The dark area in the middle of the various turns indicates the stria vascularis. The holes made in the bony wall for placing the electrodes and for perfusing the scala vestibuli are also represented. A: position of CMP electrode, B: position of ERP electrode, I: inlet for perfusion, IN: incus, M: malleus, O: outlet for perfusion, RW: round window, ST: stapes, TM: tympanic membrane, TS: tendon of musculus stapedius, TT: tendon of musculus tensor tympani.

were opened and small pieces of filter paper were introduced to remove the perilymph. Thereafter the freezing and lyophilisation procedures previously mentioned were used. For dissection, the bony cochlear capsule was carefully removed. Reissner's membrane could then be easily discerned and isolated after loosening it from ligamentum spirale and limbus spiralis with the aid of a fine hair. Any dried lymph adhering to its surfaces was carefully removed. After removal of Reissner's membrane and the dried endolymph, the epithelial structures on the membrana basilaris became visible. The organ of Corti, forming a small ridge, was localised and lifted from the basilar membrane. Enzyme assays carried out on samples of the stria vascularis, isolated before and after lyophylisation, did not reveal any significant difference in ATPase activity. 
c. ATPase determinations

$\left(\mathrm{Na}^{+}-\mathrm{K}^{+}\right)$activated and $\mathrm{Mg}^{2+}$-activated ATPase activities were determined with the method described by Bonting et al. (1963) by measuring inorganic phosphate liberated from the enzymatic breakdown of ATP in various substrate media (Table 2 ). This method is based on the

\section{Table 2}

COMPOSITION OF SUBSTRATE MEDIA USED FOR THE ASSAY

OF $\mathrm{NA}^{+}-\mathrm{K}^{+}$ACTIVATED ATPase

\begin{tabular}{lccccc}
\hline & $\mathrm{A}$ & $\mathrm{B}$ & $\mathrm{C}$ & $\mathrm{D}$ & $\mathrm{E}$ \\
\cline { 2 - 6 } $\mathrm{Mg}^{2+}$ & 1 & 1 & 1 & 1 & 1 \\
$\mathrm{Na}^{+}$ & 58 & 63 & - & 57 & 62 \\
$\mathrm{~K}^{+}$ & 5 & - & 5 & 5 & - \\
$\mathrm{CN}^{-}$ & 10 & 10 & 5 & 10 & 10 \\
EDTA & 01 & 01 & 01 & 01 & 01 \\
Tris-buffer pH 75 & 92 & 92 & 151 & 91 & 91 \\
ATP & 2 & 2 & 2 & 2 & 2 \\
Ouabain & - & - & - & 01 & 01 \\
\hline
\end{tabular}

All concentrations in mmole/l final concentration, only other ionic species present was chloride

specific properties of the $\left(\mathrm{Na}^{+}-\mathrm{K}^{+}\right)-$ATPase system. it requires for activation both $\mathrm{Na}^{+}$and $\mathrm{K}^{+}$in the presence of $\mathrm{Mg}^{2+}$ and is specifically inhıbited by cardiac glycosides such as ouabain. distınguishing it from the unspecific $\mathrm{Mg}^{2+}$-ATPase activity. Total ATPase activity was measured in medium $\mathrm{A}$, containing $\mathrm{Na}^{+}, \mathrm{K}^{+}, \mathrm{Mg}^{2+}$ and no ouabain in addition to ATP and buffer. The media B, C, D and E are inhibitory to the $\mathrm{Na}^{+}-\mathrm{K}^{+}-\mathrm{ATP}$ ase activity through the absence of $\mathrm{K}^{+}$or $\mathrm{Na}^{+}$ or the presence of ouabain or the combination of absence of $\mathrm{K}^{+}$and presence of oubain. These media give only the $\mathrm{Mg}^{2+}$ activated ATPase activity. The difference between the activity in medium $A$ and the activity in media $B, C, D$ and $E$ represents the $\mathrm{Na}^{+}-\mathrm{K}^{+}-\mathrm{ATP}$ ase activity. Lyophilised pooled tissue samples of tegmentum vasculosum, stria vascularis and ligamentum spirale were weighed on a Cahn electrobalance and homogenised in twice distilled water in an all glass Potter-Elvehjem tissue grinder $(0.04-0.15 \mathrm{mg} \mathrm{dr}$ wt $/ 100 \mu \mathrm{l})$. Aliquots of $10 \mu \mathrm{l}$ of the homogenates were added to $150 \mu \mathrm{l}$ of each of the five media. From these mixtures six aliquots of $10 \mu$ l were transferred to microtest tubes, three of which were incubated for 1 hour at $37^{\circ} \mathrm{C}$., the others remained in ice and served as enzyme blanks. Enzyme activity was stopped by adding $45 \mu 1$ of $10 \%(\mathrm{w} / \mathrm{v})$ trichloro-acetic acid to 
each tube. The same quantity of TCA was added to the blanks immediately after placing the other tubes in the incubating bath. After centrifugation, to remove precipitated protem, $30 \mu$ l of the supernatant was transferred to another microtube, containıng $30 \mu \mathrm{l}$ of a colour reagent. The colour reagent was prepared by dissolving $400 \mathrm{mg} \mathrm{FeSO}{ }_{4}$ in $5 \mathrm{ml}$ of a $1 \% \mathrm{NH}_{4}$-molybdate solution in $1.15 \mathrm{~N} \mathrm{H}_{2} \mathrm{SO}_{4}$ and was used within two hours after preparation. The resulting colour was measured between 2 and 120 minutes after mixing at $700 \mathrm{~m} \mu$ in a Zeiss spectrophotometer (PMQ II) fitted with a microcuvette attachment. In each experiment inorganic phosphate standards were included to convert the extinction into moles of inorganic phosphate liberated $/$ hour $/ \mathrm{kg} \mathrm{dry}$ wt. For this purpose $4 \mu \mathrm{l}$ of a solution of $50 \mathrm{mM} \mathrm{KH}_{2} \mathrm{PO}_{4}$ was added to $200 \mu \mathrm{l}$ and $400 \mu \mathrm{l}$ medium $\mathrm{A}$ From this mixture three aliquots of $10 \mu \mathrm{l}$ were put into microtest tubes and $45 \mu \mathrm{l}$ TCA was added. To $30 \mu 1$ of this mixture $30 \mu \mathrm{l}$ of colour reagent was also added and the resulting colour was measured. Aliquots of $10 \mu 1$ medium $A$ were treated in the same way and served as reagent blank Because collection of quantities of Reissner's membrane and organ of Cortı sufficient for homogenisation was not feasible, lyophilised samples of these structures (0.6-2.0 $\mu \mathrm{g}$ ) were weighed on a quartz-fiber balance (Lowry. 1953; Bonting and Mayron, 1961) and were directly transferred to $10 \mu \mathrm{l}$ of the incubation

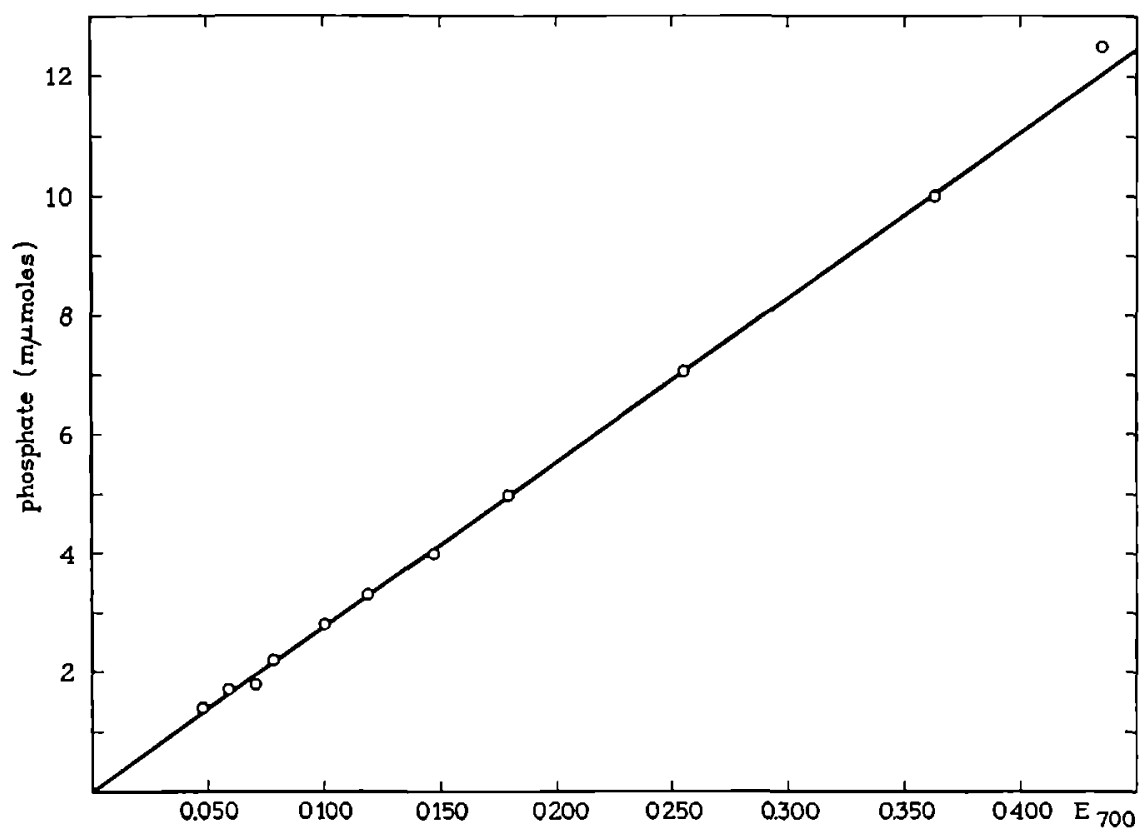

Fig 10 Calibration curve for the determination of inorganic phosphate. 
media and treated as described before. In order to check the colorimetric method with our equipment we have carried out the whole procedure with medium $A$, to which were added various amounts of inorganic phosphate. The results shown in Fig. 10 demonstrate the required linearity.

\section{Potential recording}

a. Surgical procedure

The animals were anaesthetised with sodium pentobarbital $(30 \mathrm{mg} / \mathrm{kg}$ body weight) administered intraperitoneally During the experiment additional doses were given as required to maintain deep anaesthesia The anımals were tracheotomised and the trachea was cannulated to avoid airway obstruction. In addition this allowed us to make the animal respire gas mixtures of $d_{1}$ fferent composition In order to reach the inner ear a skin incision was made in the posterior mandibular region.

The muscles and blood vessels were loosened from the mandibula and pushed away with a wound retractor. The mandibula was cut and the posterior portion removed. Thereafter the underlying muscles were retracted and the bulla tympanica became visible. From this point all further manipulations were carried out with the and of a Zeiss operating microscope With a dental drill part of the bony wall of the air filled bulla was carefully removed and the cochlea protruding into it was exposed (Fig. 9) In animals used for measuring the cochlear microphonic potentials. special care was taken to avold damage of the tympanic membrane Only animals with a middle ear cavity free of any sign of present or healed otitis were used in our experiments

In order to perfuse part of the perilymphatic space two holes of approximately $100 \mu$ were made in the bony wall of the scala vestibul, one in the middle of the second turn and the other near the oval window (Fig 9). The holes were drilled with a very fine motor driven drill, sharpened under a dissecting microscope and mounted on a micromanipulator In the anımals used for measuring the cochlear microphonic potential a third hole was made between the previous two. for insertion of the wire electrode ( $\left.F_{1 g} 9\right)$. For measuring the endolymphatic potential a small window was made in the same region, just above the scala media, allowing us to place a glass capillary electrode into the endolymphatic space

\section{b Cochleat microphonic potential}

All potential recordings were carried out in a soundproof, electrically shielded room. The microphonic potential was recorded by means of a nichrome wire electrode $(100 \mu)$ placed in the hole made in the scala vestibuli in the middle of the first turn ( $\left.F_{1 g} 9\right)$ and an indifferent 
electrode in the neck tissue. The recording electrode was insulated by dipping it into a resin solution, leaving small globules on the wire surface. The wire was cut just beyond one of those globules, thus preventing too deep penetration of the electrode into the scala vestibuli as well as outflow of the perfusion fluids.

The cochlear signals were amplified $(1000 \mathrm{x})$ with a Tektronix differential amplifier and from there displayed on an oscilloscope screen and registered. The sound stimuli, consisting of pure tones in the frequency range of 500-8.000 cps, intensity $80 \mathrm{~dB}$ re $0.0002 \mathrm{dyn} / \mathrm{cm}^{2}$, were produced by a condensor telephone driven by a beat frequency oscillator (Brüel and Kjoer, type 1014). This telephone was fixed in a small polyethylene container, which was fitted in an ear speculum. The speculum was securely fixed in the external auditory meatus. Sound pressure was measured with the aid of a probe microphone in the side wall of the container. The quality of the sound stimulus could be observed by visualizing the output of the probe microphone on the oscilloscope screen. The stimulating and recording circuit are schematically represented in fig. 11 .

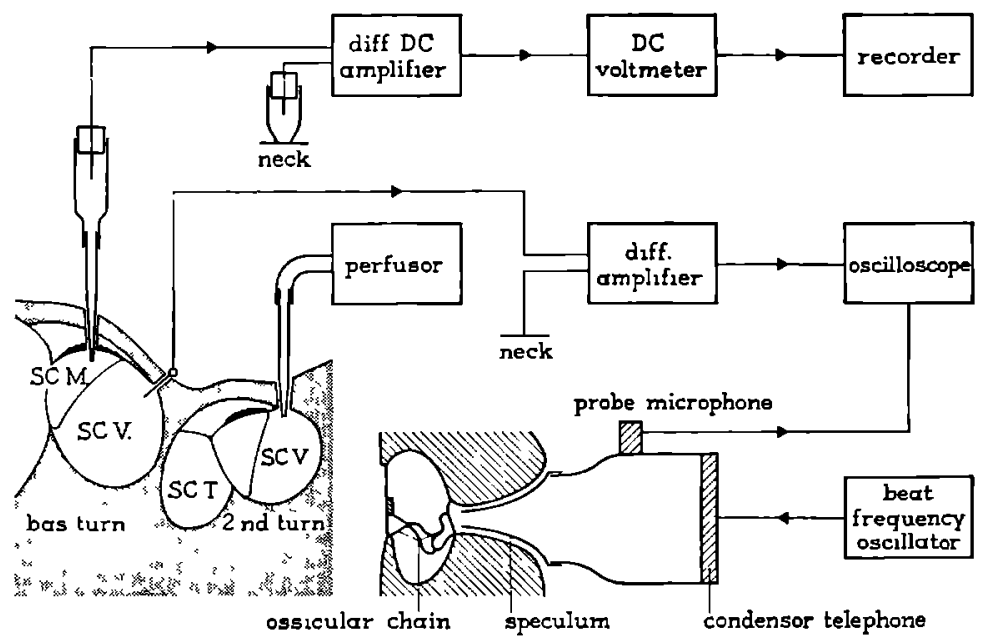

Fig. 11. Schematic representation of the equipment used for recording the cochlear potentials and for perfusing scala vestibulı. The upper part of this figure shows the recording circuit for the endolymphatic resting potential (ERP), the lower part the stimulating and recording circuit for the cochlear microphonic potential (CMP).

\section{c. Endolymphatic resting potential}

The endolymphatic resting potential was measured with glass pipette electrodes with tip diameters ranging from $5-15 \mu$ and filled with isotonic $\mathrm{KCl}$ solution. The pipettes were fixed with wax into a wider glass 
tube filled with the same solution and containing a chloride coated silver wire. The silver wire was connected to a DC voltage amplifier (S.M I.: Rijswilk, The Netherlands, type MB-01) with an input impedance of $10^{12} \Omega$ and a grid current of $10^{-12} \mathrm{~A}$. The output of the DC amplifier was delivered to a DC microvoltmeter (Philips, GM 6020) and read directly from the scale, or fed to a recorder for permanent recordings. A chloride coated silver wire, housed in a wide tube filled with Ringer and placed in the neck tissue served as the reference electrode.

Before penetrating the endolymphatic space the pipette electrode. mounted on a micromanipulator, was brought into contact with the ligamentum spirale, previously exposed by removing the bony capsule ( $F_{1}$. 9). After compensating for the junction potential, the pipette was slowly advanced through the ligamentum spirale and stria vascularis until the positive endocochlear potential was observed, which remained constant upon further penetration. When measuring this potential. special care was taken to $f_{1 x}$ the head of the animal firmly to the operating table with a metal holder. Sudden movements would damage the cells of the stria vascularis in the neighbourhood of the electrode or even disrupt Reissner's membrane, resulting in a decrease of the potential.

At the end of the experiments the electrode was withdrawn and checked on the outer side of the ligamentum spirale for any change in the junction potential. The recording carcuit is given in $\mathrm{F}_{1 \mathrm{~g}} 11$.

\section{d. Perfusion technique}

Perfusion of the perilymphatic space (scala vestibuli) was performed by inserting a small glass pipette (75-100 $\mu$ tip diameter) in the hole made in the second turn of the scala vestibulı (Figs. 9 and 11). Because this hole was tapered, the pipette could be inserted without any significant leakage of fluid. This glass pipette was connected by a small polyethylene tube to a mechanically driven all-glass syringe. The hole in the scala vestibuli near the oval window served as an outlet. The outflowing fluid was absorbed by small plugs of cotton wool in the bottom of the middle ear cavity. The excess fluid was removed by continuous suction, thus avoiding massive entry of the perfused substances into the circulation and at the same time keeping the fluid away from the windows. The cochlear microphonic potential appeared to be depressed when fluid accumulated at the windows, probably because sound transmission was decreased. Suction had to be done silently, since any noise close to the inner ear depressed the cochlear microphonic potential and also had some slight effect on the endolymphatic potential. 
In most experiments the stability of the potentials was checked by perfusing the perilymphatic space for five minutes with a normal Ringer solution. In this way pressure effects, caused by obstruction of the outflow opening or injury of the epithelial wall of the endolymphatic space both resulting in changes in cochlear potentials, could be excluded.

The routinely used perfusion rate was $10 \mu 1 / \mathrm{m}$ n. The volume of the perfused space, as calculated from the cochlear dimensions reported by Fernández (1952), is approximately $3 \mu \mathrm{l}$, and the perilymph production varies between 1 and $3 \mu \mathrm{l} / \mathrm{min}$. (Rauch, 1964). Therefore this perfusion rate seemed to be sufficient to replace the perilymph completely. All fluids used for perfusion were gassed with a mixture of $95 \% \mathrm{O}_{2}-5 \% \mathrm{CO}_{2}$ and slightly warmed. The $\mathrm{pH}$, measured immediately before the start of perfusion, was 7 3-7.4 and appeared to be raised to 7.8-7.9 after 60 min. perfusion. The composition of the standard perfusion fluid, which showed no effect on the cochlear potentials is given in Table 3. This fluid will be indicated as Ringer or normal Ringer's solution.

Table 3

COMPOSITION OF THE PERFUSING FLUID *

\begin{tabular}{lc}
\hline $\mathrm{NaCl}$ & 124 \\
$\mathrm{KCl}$ & 3 \\
$\mathrm{CaCl}_{2}$ & 13 \\
$\mathrm{MgCl}_{2}$ & 08 \\
$\mathrm{NaHCO}_{3}$ & 25 \\
$\mathrm{KH}_{2} \mathrm{PO}_{4}$ & 05 \\
$\mathrm{~K}_{2} \mathrm{HPO}_{4}$ & 05 \\
\hline
\end{tabular}

* All concentrations in mmole/l, $\mathrm{pH}$ adjusted to 74 


\section{OCCURRENCE AND DISTRIBUTION OF THE $\mathrm{Na}^{+}-\mathrm{K}^{+}-$ATPase ACTIVITY IN THE CHICKEN COCHLEA}

\section{Introduction}

Although the avallable data are not as exact as those for mammalian cochlea, the endolymph of the avian cochlea appears to contain three times more potassium than sodium (Johnstone et al., 1963). This implies the existence of a cation gradient, which has to be maintained by an active cation transport mechanism. Moreover the cochlear potentials. which are present in mammals and have there been shown to be dependent on the cation composition of the cochlear fluids (Chapter III) have also been demonstrated in birds (Schmidt and Fernández, 1962. Schmidt, 1963). Therefore it seemed justıfied to look for the presence and localisation of the $\mathrm{Na}^{+}-\mathrm{K}^{+}$-ATPase activity, shown to be intimately involved in active cation transport. The dissection of the cochlear structures of one day old chickens is easier than in mammals, because the chicken skull consists mainly of cartilage and soft bone. Hence we started enzyme assays on these structures, rather than on the guinea pig cochlear structures.

\section{Distribution of the $\mathrm{Na}^{+}-\mathrm{K}^{+}-\mathrm{ATPase}$ activity} in the chicken cochlea

The cochlear structures of one day old chickens (Chapter I, 11) were dissected and lyophilised as reported in Chapter V, 2. The ATPase activities were determined in the various substrate media mentioned in Chapter V, 2. The $\mathrm{Na}^{+}-\mathrm{K}^{+}-\mathrm{AT}$ Tase activity is represented by that part of the ATPase activity in the complete medium, that can be inhibited by the omission of $\mathrm{Na}^{+}$or $\mathrm{K}^{+}$or by the addition of ouabain. Enzyme assays on the whole cochlear sac revealed an absolute activity for $\mathrm{Na}^{+}-\mathrm{K}^{+}$-ATPase of 1.9 (SE: 0.4) and for $\mathrm{Mg}^{2+}$-ATPase of 4.2 (SE: 1.0 ) expressed in moles ATP hydrolysed per $\mathrm{kg}$ dry weight per hour at $37^{\circ} \mathrm{C}$ (Table 4 ).

In order to look for the distribution of the enzyme activity in the various structures of the cochlea, the tegmentum vasculosum was dissected and separately assayed for enzyme activity. The relative ATPase 
REI ATIVI ACTIVITILS IN TEGMENTUM VASCULOSUM HOMOGENATES

\begin{tabular}{lc} 
Medium & $\%$ \\
\hline A (complete) & 100 \\
B (no $\left.\mathrm{K}^{+}\right)$ & $66,6 \pm 31$ \\
$\mathrm{C}\left(\right.$ no $\left.\mathrm{Na}^{+}\right)$ & $653 \pm 42$ \\
$\mathrm{D}\left(10^{-4} \mathrm{M}\right.$ ouabain $)$ & $663 \pm 59$ \\
$\mathrm{E} \mathrm{(no} \mathrm{K}^{+}, 10^{-4} \mathrm{M}$ ouabain) & $593+30$ \\
Average for media B, C, D and E & $644 \pm 32$
\end{tabular}

ABSOLUTE ACTIVITIES

$\mathrm{Na}^{+} \mathrm{K}^{+}$-ATPase $\mathrm{Mg}^{2+}$-ATPase

Whole cochlear sac $\quad 19 \pm 04 \quad 42+10$ (3)

Teqmentum vasculosum $\quad 50 \pm 05 \quad 93 \pm 10(7)$

Relative activities qiven with SE for 5 determinations Absolute activities (means with $\mathrm{SE}$ and in parentheses number of determinations) are expressed in moles ATP hydrolysed per $\mathrm{kg}$ dry weight per hour at $37^{\circ} \mathrm{C}$

activities in the various substrate media and the absolute activities are given in Table 4 It appears from these data that the $\mathrm{Na}^{+}-\mathrm{K}^{+}-$ATPase activity is predominantly located in the tegmentum vasculosum, which has an activity of 50 moles $/ \mathrm{kg}$ dry $\mathrm{wt} / \mathrm{hr}$.

The four inhibitory media caused approximately the same degree of inhibition, so the $\mathrm{Na}^{+}-\mathrm{K}^{+}-\mathrm{ATP}$ ase activity represents $36 \%$ of the total ATPase activity.

\section{Properties of ATPase activity}

As demonstrated in various tissues there is an agreement in the effect of cations on the $\mathrm{Na}^{+}-\mathrm{K}^{+}-\mathrm{ATP}$ ase activity and on the cation transport system (Chapter IV). Therefore the effects of $\mathrm{Mg}^{2+}, \mathrm{Na}^{+}$and $\mathrm{K}^{+}$on the $\mathrm{Na}^{+}-\mathrm{K}^{+}-\mathrm{ATP}$ Pase activity of the chicken tegmentum vasculosum were studied In addition the inhibition by oubain and the $\mathrm{pH}$ dependence were determined.

The effect of $\mathrm{Mg}^{2+}$ on the ATPase activities shown in Fig 12, was investigated by varying the $\mathrm{Mg}^{2+}$ concentration from $0-6 \mathrm{mM}$ in the media $A$ and $E$ containing 2 mM ATP. Medium E gave $\mathrm{Mg}^{2+}$ ATPase activity, while the difference between the activities in medium $A$ and $E$ gave $\mathrm{Na}^{+}-\mathrm{K}^{+}-\mathrm{ATP}$ ase activity. A slight activity of both ATPase actıvities was present without added $\mathrm{Mg}^{2+}$. $\mathrm{Na}^{+} \mathrm{K}^{+}$activated $\mathrm{ATP}$ ase was maximal at $1 \mathrm{mM} \mathrm{Mg}^{2+}$ and $\mathrm{Mg}^{2+}$ activated ATPase at $2 \mathrm{mM} \mathrm{Mg}{ }^{2+}$. 


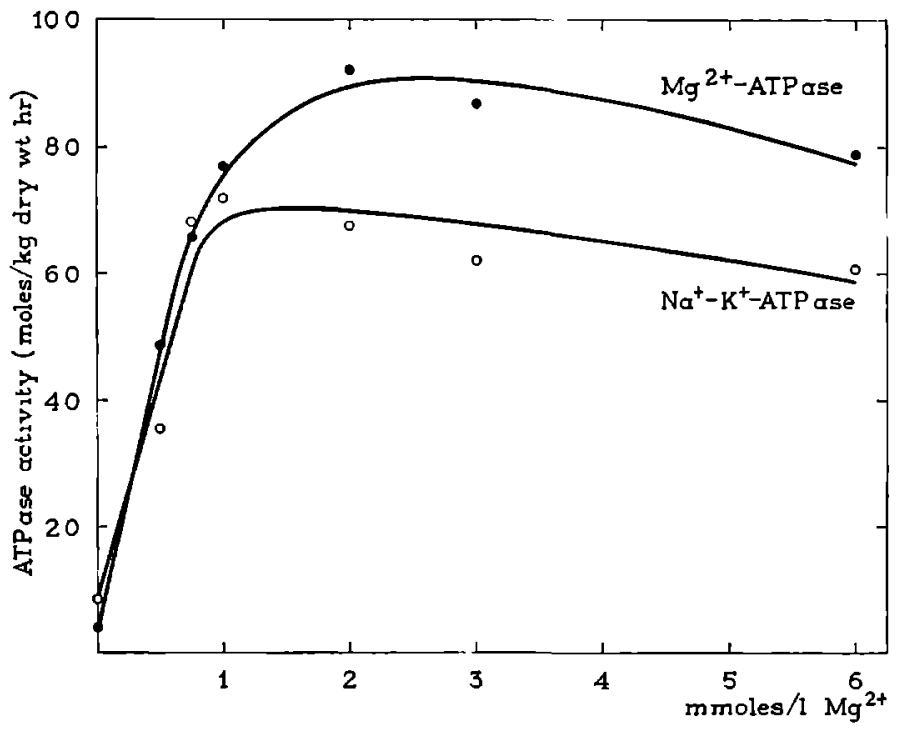

Fig 12 Fiffect of $\mathrm{Mq}^{2+}$ concentration on $\mathrm{Na}^{4}-\mathrm{K}^{+}$ATPase activity $(\mathrm{O}--\mathrm{o})$ and $\mathrm{Mg}^{2+}$ ATPase activity (- $\bullet$ ) in homogenates of chicken tegmentum vasculosum Activities were measured in media $A$ and $E$ to which $\mathrm{MgCl}_{2}$ (0-6 mM) was added Medium $\mathrm{E}$ (no $\mathrm{K}^{+} 10^{-4} \mathrm{M}$ ouabain) gave $\mathrm{Mq}^{2+}$-ATPase activity, while the difference between activities in media $A$ (complete) and $\mathrm{E}$ gave $\mathrm{Na}^{+}-\mathrm{K}^{+}-\mathrm{ATP}$ ase activity.

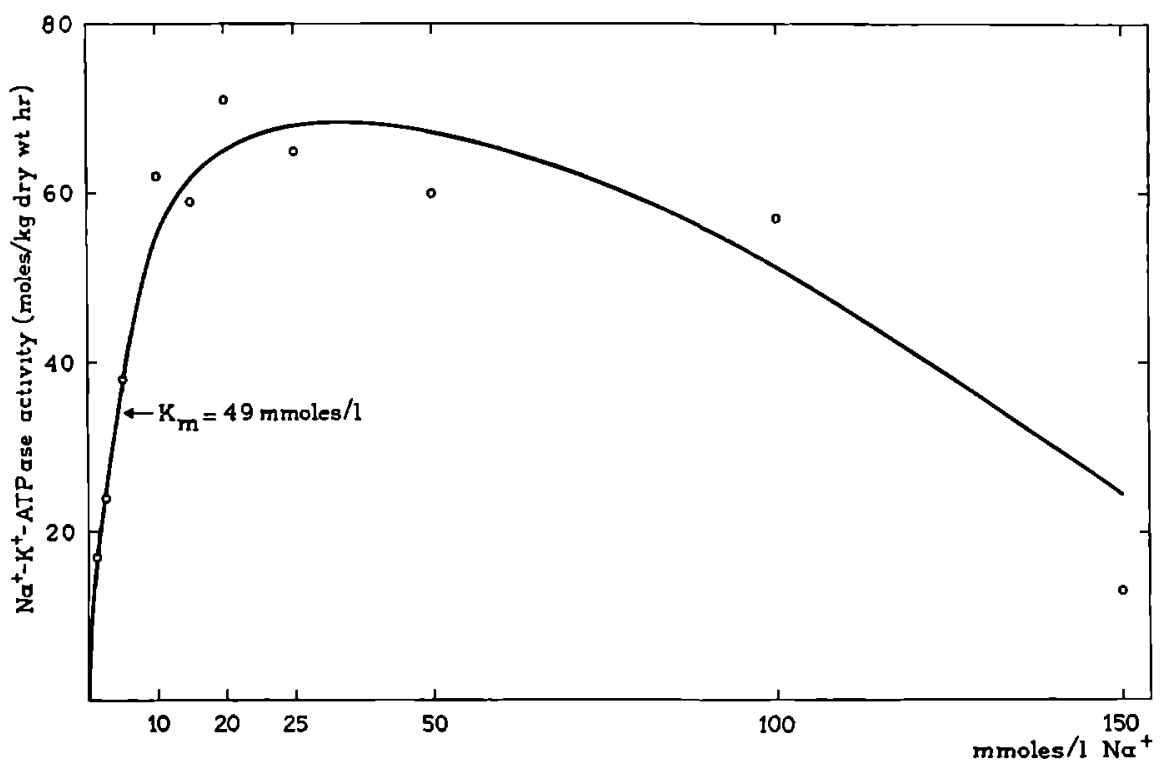

$F_{19} 13$ Effect of $\mathrm{Na}^{+}$concentration on $\mathrm{Na}^{+}-\mathrm{K}^{+}$-ATPase activity in homoqenates of chicken tegmentum vasculosum Increasing amounts of $\mathrm{NaCl}$ were added to medium $\mathrm{C}$ (no $\mathrm{Na}^{+}$), while the $\mathrm{K}^{+}$concentration was kept at $5 \mathrm{mM}$ 
Therefore the enzyme activities obtained from our routinely used medium, containing $1 \mathrm{mM} \mathrm{Mg}{ }^{2+}$ represent the optımal $\mathrm{Na}^{+}-\mathrm{K}^{+}$-ATPase activity but only $84 \%$ of the optimal $\mathrm{Mg}^{2+}$-ATPase activity.

The $\mathrm{Na}^{+}$-activation curve, in the presence of $5 \mathrm{mM} \mathrm{K}{ }^{+}$for the $\mathrm{Na}^{+}-\mathrm{K}^{+}$-ATPase system is shown in Fig. 13. The activity was measured in medium $\mathrm{C}$ to which increasing amounts of $\mathrm{NaCl}$ were added $(0-150 \mathrm{mM})$. Maximal activity was obtamed at $25 \mathrm{mM} \mathrm{Na}{ }^{+}$, while at higher $\mathrm{Na}^{+}$concentrations the enzyme activity decreased to about $30 \%$ of the maximal activity. Half maximal activation occurred at $4.9 \mathrm{mM}$ $\mathrm{Na}^{+}$.

The activation of the $\mathrm{Na}^{+}-\mathrm{K}^{+}-\mathrm{ATP}$ ase system by $\mathrm{K}^{+}$in the presence of $63 \mathrm{mM} \mathrm{Na}^{+}$is shown in Fig. 14. This curve was obtained by adding graded amounts of $\mathrm{KCl}$ to medium $\mathrm{B}\left(\mathrm{no} \mathrm{K}^{+}\right)$. Maximal activation of

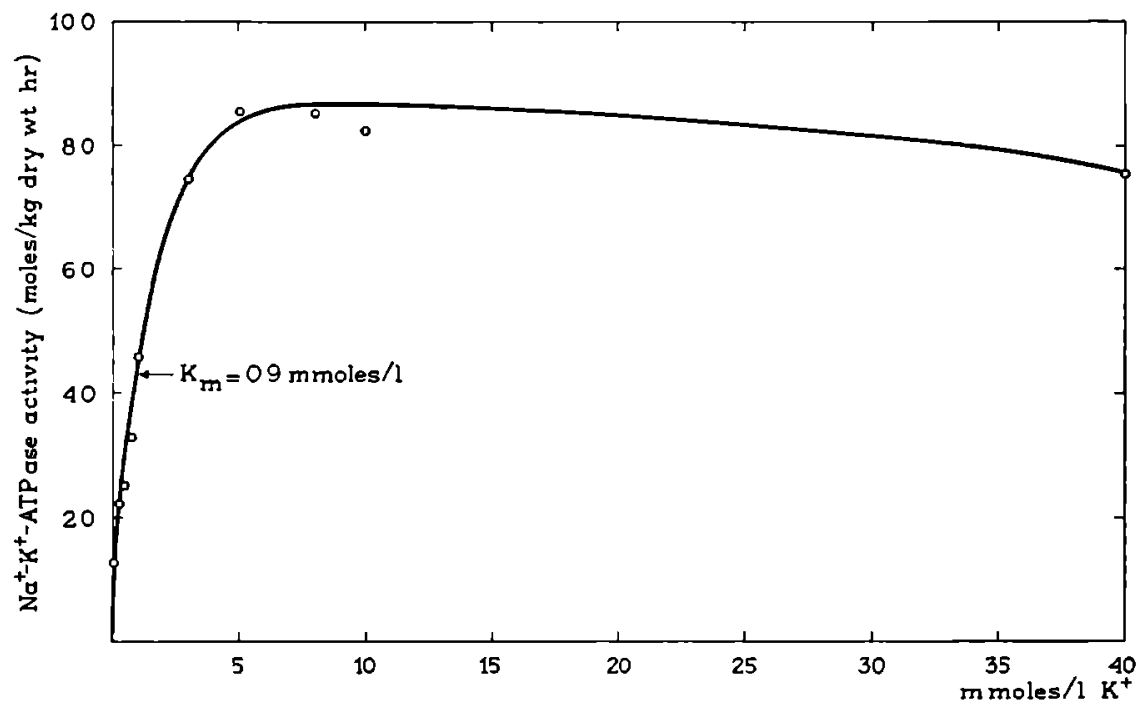

Fig 14 Effect of $\mathrm{K}^{+}$concentration on $\mathrm{Na}^{+}-\mathrm{K}^{+}$-ATPase activity in homogenates of chicken tegmentum vasculosum Graded amounts of $\mathrm{KCl}$ were added to medium $\mathrm{B}$ (no $\mathrm{K}^{+}$), keepıng the $\mathrm{Na}^{+}$concentration at $63 \mathrm{mM}$ Medium $\mathrm{E}$ (no $\mathrm{K}^{+}, 10^{-1} \mathrm{M}$ ouabain) qave $\mathrm{Mg}^{2+}$.ATPase activity

the $\mathrm{Na}^{+}-\mathrm{K}^{+}-\mathrm{ATPase}$ was obtained with $5 \mathrm{mM} \mathrm{K}$, while higher concentrations were slightly inhibitory. Half maximal activation occurred at $0.9 \mathrm{mM} \mathrm{K}$. The slight activity without added $\mathrm{KCl}$, is presumably due to partial activation of the enzyme by a small amount of tissue potassium, since the activity in medium $\mathrm{B}$ without $\mathrm{K}^{+}$appeared to be higher than in medium $\mathrm{E}$ (no $\mathrm{K}^{+}, 10^{-4} \mathrm{M}$ ouabain), which was considered to represent only $\mathrm{Mg}^{2+}-$ A TPase activity (Table 4). 
The inhibitory effect of ouabain in various concentrations on the $\mathrm{Na}^{+}-\mathrm{K}^{+}-\mathrm{ATPase}$ activity is given in Fig. 15. This inhibition was deter-

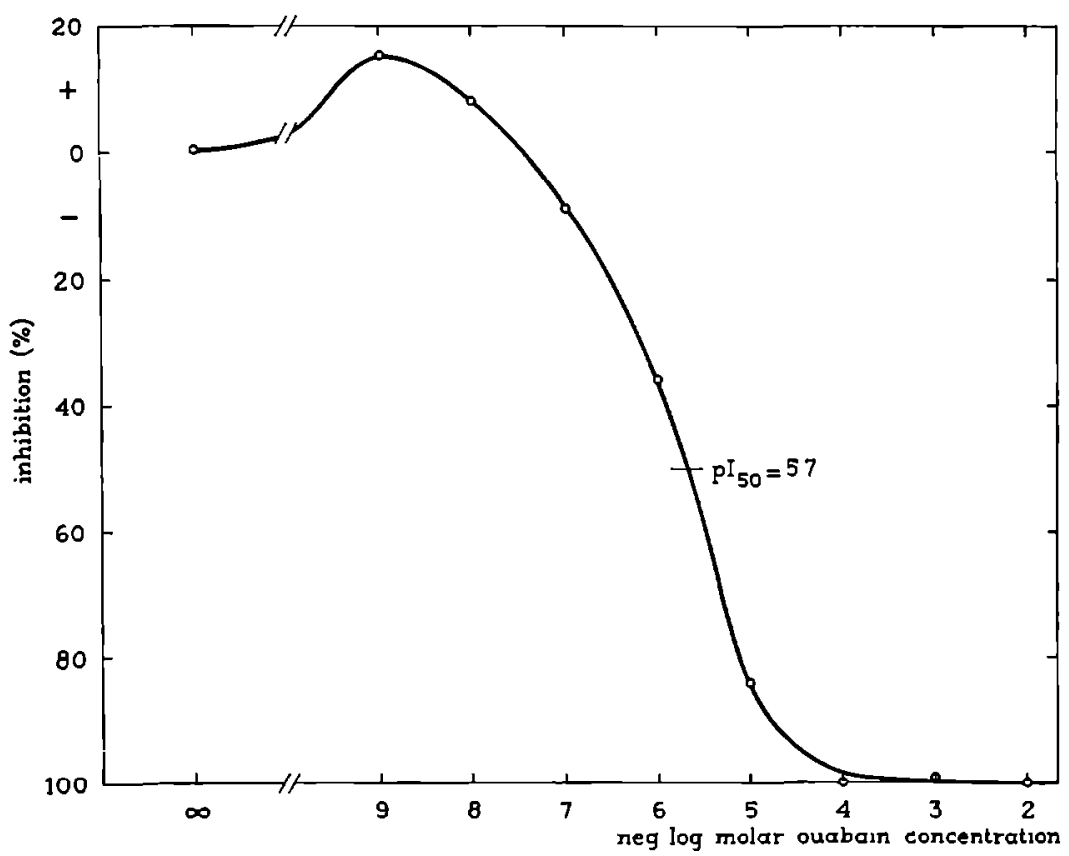

$F_{1 g}$. 15. Effect of ouabain on $\mathrm{Na}^{+}-\mathrm{K}^{+}$-ATPase activity in homogenates of chicken tegmentum vasculosum. ATPase activity was determined in medium A contanning varıous concentrations ouabain $\left(10^{-9}-10^{-2} \mathrm{M}\right.$ ). The activity in medium $\mathrm{E}$ (no $\mathrm{K}^{+}$, $10^{-1} \mathrm{M}$ ouabain) was taken to represent $\mathrm{Mg}^{2+}$-ATPase alone. The plin is the negative logarithm of the molar ouabain concentration causing $50 \%$ inhibition.

mined by measuring enzyme activity in medium $A$ to which ouabain was added $\left(10^{-2}-10^{-9} \mathrm{M}\right.$ ). The activity in medium $\mathrm{E}$ (no $\mathrm{K}^{+}, 10^{-4} \mathrm{M}$ ouabain) was taken to represent $\mathrm{Mg}^{2+}-\mathrm{ATP}$ ase activity alone. The negative logarithm of the half maximal inhibition concentration was 5.7. Maximal inhibition was obtained at $10^{-4} \mathrm{M}$, the same concentration as routinely used in our substrate media. A slight stimulation of 15 (SE: $2.2) \%$ occurred at very low ouabain concentrations $\left(10^{-8} \mathrm{M}\right)$.

The $\mathrm{pH}$-activity curve was obtained by measuring ATPase activities in the media $\mathrm{A}$ and $\mathrm{E}$, prepared with $\mathrm{Tris}-\mathrm{HCl}$ buffers in the $\mathrm{pH}$ range from 6.5-9.5. The $\mathrm{pH}$ optimum for the $\mathrm{Na}^{+}-\mathrm{K}^{+}-\mathrm{AT}$ Pase was 7.3 and for $\mathrm{Mg}^{2+}$-ATPase 8.4 as shown in Fig. 16.

4. Discussion and conclusions

From the data presented in Table 4 and Figs. 12 to 16 it may be con- 
Table 5

PROPERTIES OF THE $\mathrm{Na}^{+}-\mathrm{K}^{+}$-ATPase SYSTEM IN VARIOUS SPECIES AND TISSUES

\begin{tabular}{|c|c|c|c|c|c|c|c|c|c|c|}
\hline \multirow[b]{2}{*}{ Tissue } & \multirow[b]{2}{*}{ Species } & \multicolumn{6}{|c|}{$\mathrm{Na}^{+}-\mathrm{K}^{+}-\mathrm{AT}$ Pase } & \multicolumn{2}{|c|}{$\mathrm{Mg}^{2+}$-ATPase } & \multirow[b]{2}{*}{ Reference } \\
\hline & & $\begin{array}{c}\mathrm{Mg}^{2+}-\mathrm{ATP} \\
\text { opt }\end{array}$ & $\begin{array}{l}\mathrm{Nad}_{\mathrm{m}}^{+} \\
\mathrm{K}_{\mathrm{m}}\end{array}$ & $\begin{array}{l}\mathrm{K}^{+} \\
\mathrm{K}_{111}\end{array}$ & $\begin{array}{l}\mathrm{pH} \\
\text { opt }\end{array}$ & $\begin{array}{c}\text { ouabain } \\
\text { pI } 50\end{array}$ & $\begin{array}{l}\text { activity } \\
\text { MKH }\end{array}$ & $\begin{array}{l}\text { activity } \\
\text { MKH }\end{array}$ & $\begin{array}{l}\mathrm{pH} \\
\text { opt }\end{array}$ & \\
\hline Nerve & Crab & 2 & $6-8$ & 18 & 72 & 39 & - & - & - & Skou $(1957,1960)$ \\
\hline Intestine & Gunnea pig & - & 10 & 05 & $75-80$ & 54 & - & - & - & Taylor (1962) \\
\hline Salt gland & Herring gull & 15 & 125 & 15 & 72 & 63 & $27 w$ & $14 w$ & 87 & Bonting et al (1964a) \\
\hline $\begin{array}{l}\text { Lens } \\
\text { epithelium }\end{array}$ & Rabbit & - & - & 04 & 73 & 59 & $015 w$ & $006 w$ & 84 & Bonting (1965) \\
\hline $\begin{array}{l}\text { Rectal } \\
\text { gland }\end{array}$ & $\begin{array}{l}\text { Spiny } \\
\text { dogfish }\end{array}$ & 15 & 117 & 10 & 70 & 68 & $57 d$ & $29 d$ & 89 & Bonting (1966) \\
\hline E colı & E colı & 1 & - & 43 & 77 & \pm 4 & $024 d$ & $25 \mathrm{~d}$ & $87-8$ & $\begin{array}{l}\text { Hafkenscheid and Bontıng } \\
(1968,1969)\end{array}$ \\
\hline Liver & Rat & 1 & 6 & 09 & 73 & 39 & 037 & $36 d$ & 87 & $\begin{array}{l}\text { Bakkeren and Bontıng } \\
(1968)\end{array}$ \\
\hline Pancreas & Rabbit & 15 & 10 & 08 & 72 & 54 & $023 \mathrm{~d}$ & $27 \mathrm{~d}$ & 88 & $\begin{array}{l}\text { Ridderstap and Bonting } \\
1969 a, b)\end{array}$ \\
\hline Kidney & Rat & 05 & 8 & 07 & 74 & 39 & $68 d$ & $93 \mathrm{~d}$ & 87 & $\begin{array}{l}\text { vd Beek an Bonting, } \\
\text { unpublished }\end{array}$ \\
\hline
\end{tabular}

$\mathrm{Mg} / \mathrm{ATP}$ opt molar ratio of $\mathrm{Mg}^{2-}$ to ATP at which maximal activity occurs

$\mathrm{Na}^{+} \mathrm{K}_{\mathrm{m}}$ half-maximal activation concentration for $\mathrm{Na}^{+}$in meq/l at $\mathrm{K}^{+}$concentration of about 5 meg/l

$\mathrm{K}^{+} \mathrm{K}_{\mathrm{m}}^{\mathrm{m}}$ half-maximal activation concentration for $\mathrm{K}^{-}$in meq/l at $\mathrm{Na}^{+}$concentration of about 60 meq/l

$\underset{\omega}{\mathrm{p} H}$ opt $\mathrm{pH}$ optımum

ouabain $\mathrm{pI}_{50}$ negative log molar concentration for $50 \%$ inhibition

activity MKH activity in moles $/ \mathrm{kg} / \mathrm{hr}, \mathrm{d}=$ on dry wt basis, $w=$ on wet wt basis 


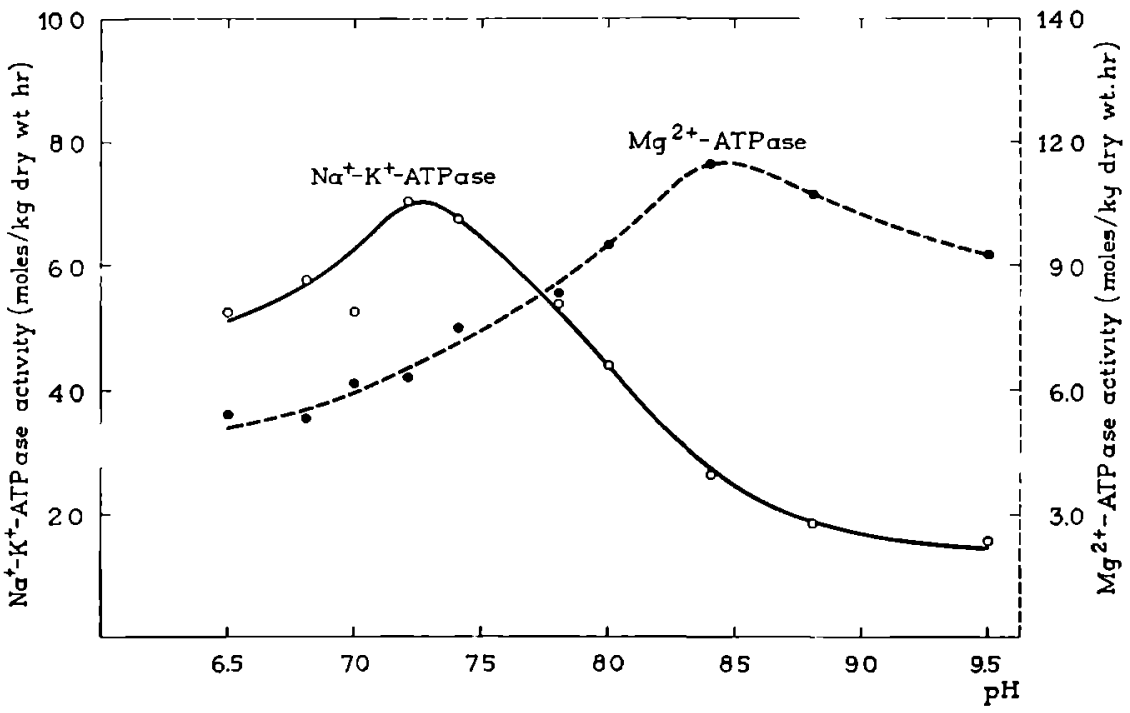

Fig. 16. Effect of $\mathrm{pH}$ on $\mathrm{Na}^{+}-\mathrm{K}^{+}-\mathrm{ATP}$ ase activity $\mathrm{o}-\mathrm{o}$ and $\mathrm{Mg}^{2+}$-ATPase activity -... in homogenates of chicken tegmentum vasculosum. The $\mathrm{pH}$ dependence was measured in media $A$ (complete) and $E$ (no $K^{\vdash}, 10^{-1} \mathrm{M}$ ouaban), prepared with Tris-buffers in a $\mathrm{pH}$ range from 6.5-9.5. The $\mathrm{Mg}^{2+}$.ATPase activity was measured in medium $\mathrm{F}$, while the $\mathrm{Na}^{+}-\mathrm{K}^{-}$-ATPase activity was calculated from the difference between activities in media $\mathrm{A}$ and $\mathrm{E}$.

cluded that the the inner ear structures of the one day chicken contain a $\mathrm{Na}^{+}-\mathrm{K}^{+}-\mathrm{AT}$ Pase system similar to that described by Skou (1957. 1960) in crab nerve, by Post et al. (1960) and by Dunham and Glynn (1961) in erythrocytes and by Bonting et al. (1962) and Bonting and Caravaggio (1963) in a great number of tissues in which cation transport against an electrochemical gradient occurs.

As demonstrated in Table 4 and Figs, 12 to 16 , the enzyme system requires besides $\mathrm{Mg}^{2+}$ both $\mathrm{Na}^{+}$and $\mathrm{K}^{+}$for activation and is inhibited by ouabain. The concentrations of $\mathrm{Na}^{+}\left(\mathrm{K}_{\mathrm{m}}=4.9 \mathrm{mM}\right)$ and $\mathrm{K}^{+}\left(\mathrm{K}_{\mathrm{m}}=\right.$ $0.9 \mathrm{mM}$ ) giving half maximal activation are in good agreement with those found in other tissues (Table 5). The same applies for the $\mathrm{pH}$ optimum of 7.3 of the $\mathrm{Na}^{+}-\mathrm{K}^{+}-\mathrm{ATP}$ ase activity, while this optimum is very different from that found for the residual oubain-insensitive $\mathrm{Mg}^{2+}$-ATPase activity $(\mathrm{pH}=8.4)$. The half inhibition concentration of ouabain $\left(\mathrm{pI}_{50}=5.7\right)$ is not very different from the value of 5.3. reported for the $\mathrm{Na}^{+}-\mathrm{K}^{+}$-ATPase activity in chicken kidney homogenates (Palmer and Nechay, 1964). The stimulatory effect of very low ouabain concentrations has also been demonstrated in the chicken kidney, both for the enzyme activity in homogenates and also for the tubular reabsorption of $\mathrm{Na}^{+}$and water in vivo (Palmer and Nechay, 
1964). Similar biphasic effects have been reported for the production of cerebrospinal flud (Oppelt and Palmer, 1966) and pancreatic juice (Ridderstap and Bonting, $1969 \mathrm{~b}$ ).

As shown in Table 4, the $\mathrm{Na}^{+}-\mathrm{K}^{+}-$ATPase activity appeared to be predominantly located in the tegmentum vasculosum. This structure representing about $30 \%$ of the dry weight of the whole cochlear sac, showed an activity of 5.0 moles $/ \mathrm{kg}$ dry wt $/ \mathrm{hr}$, while the enzyme act1vity of the total structure is only 1.9 moles $/ \mathrm{kg}$ dry wt $/ \mathrm{hr}$. This means that the rest of the cochlear structures has an activity of only 0.6 moles $/ \mathrm{kg}$ dry wt $/ \mathrm{hr}$. The $\mathrm{Na}^{+}-\mathrm{K}^{+}$-ATPase activity of the tegmentum vasculosum is high in comparison with other tissues (Bonting et al., 1961 a). The actual value may be even higher, as may be concluded from the activities obtained in Figs. 12 to 16 . In those experiments a more complete removal of the sticky endolymph from the tegmentum vasculosum could be obtained, resulting in an enhancement of the enzyme activity to about 7 moles $/ \mathrm{kg}$ dry wt/hr. Such high $\mathrm{Na}^{+}{ }_{-} \mathrm{K}^{+}$ ATPase activities have only been demonstrated in epithelia with a secretory function like the nasal gland of marine birds (Bonting et al., 1964 a), the rectal gland of elasmobranchs (Bonting, 1966), the choriord plexus (Vates et al , 1964), kidney (Bontıng et al., 1961 a; Bonting et al., 1962) and in excitatory tissues like retina (Bontıng et al., $1964 \mathrm{c}$ ), brain tissue (Bonting et al., 1962) and the electroplax of the electric eel (Bonting et al,, $1961 \mathrm{~b}$ ).

Bignami et al. (1966) showed that the $\mathrm{Na}^{-}-\mathrm{K}^{+}-\mathrm{ATP}$ ase activity in developing chicken brain increased parallel with the electrical activity, reaching about $80 \%$ of the adult value at hatching. Since the inner ear of the one-day chicken has a nearly adult frequency response pattern (Vanzullı and Garcia Austt, 1963), it seems likely that the above enzyme activities closely approach those of the adult chicken cochlea.

It seems likely that the $\mathrm{Na}^{+}-\mathrm{K}^{+}$-ATPase system, present in high activity in the tegmentum vasculosum. functions in maintaining the high $\mathrm{K}^{+}$and low $\mathrm{Na}^{-}$concentration of the endolymph. An additional argument for this role of the tegmentum vasculosum can be derived from its fine structure. Jahnke et al. (1969) demonstrated a great structural similarity between the tegmentum vasculosum and epthelia involved in cation transport like kidney tubules (Pease, 1955), part of the labyrinthine epithelium (Dohlman, 1965. Kımura, 1969) and the nasal gland of marine birds (Doyle, 1960). In addition, the assumption that phylogenetically the tegmentum vasculosum represents both stria vascularıs and Reissner's membrane of the mammalian cochlea, is supported by the high $\mathrm{Na}^{+}-\mathrm{K}^{+}$-ATPase activities in both tegmentum vasculosum and stria vascularıs as will be shown in Chapter VII. 


\section{OCCURRENCE AND DISTRIBUTION OF $\mathrm{Na}^{+}-\mathrm{K}^{+}-\mathrm{ATP}$ Tase} ACTIVITY IN THE COCHLEAR STRUCTURES OF THE GUIINEA PIG

\section{Introduction}

The presence and distribution of the $\mathrm{Na}^{+}-\mathrm{K}^{+}-\mathrm{ATPase}$ system in the highly differentiated cochlear of the guinea pig was studied in order to investigate the involvement of this enzyme system in the maintenance of the high $\mathrm{K}^{+}$and low $\mathrm{Na}^{+}$concentrations in the endolymph. The anatomical position of the inner ear in this animal also permitted us to investigate the role of the $\mathrm{Na}^{+}-\mathrm{K}^{+}$-ATPase system in the generation of the cochlear potentials by topical application of ouabain in the living animal. This appeared to be impossible in the chicken as will be discussed later on. The choice of the guinea pig was also guided by the considerations that the fine structure of the cochlear tissues, the cochlear fluid composition and the cochlear potentials have been studied in great detail (Chapters I, II and III), and that an ouabain-sensitive active transport of $\mathrm{K}^{+}$from per1- to endolymph has been demonstrated in this animal (Rauch, 1966).

2. Presence and properties of the $\mathrm{Na}^{+}-\mathrm{K}^{+}-\mathrm{A} \mathrm{TPa}$ P system

Preliminary enzyme studies on lyophilised fragments of the total membranous structure of the guinea pig cochlear by incubation in the various substrate media, described in Chapter $\mathrm{V}$, revealed a high ouabainsensitive $\mathrm{Na}^{+}-\mathrm{K}^{+}-\mathrm{ATP}$ ase activity of 0.8 (SE. 0.3 ) and a residual $\mathrm{Mg}^{2+}$-ATPase activity of 10 (SE: 0.4), both expressed in moles ATP hydrolysed per $\mathrm{kg}$ dry weight per hour. On further dissection it appearcd that the $\mathrm{Na}^{+} \mathrm{K}^{+}-\mathrm{ATPas}$ activity was predominantly localised in the stria vascularis. The properties of the $\mathrm{Na}^{+}-\mathrm{K}^{+}-\mathrm{ATP}$ Tase activity have therefore been investigated in ho.nogenates of the stria vascularis. collected from different turns. From an activity versus time curve it appeared that the hydrolysis of $\mathrm{ATP}$ at $37^{\circ} \mathrm{C}$ by $\mathrm{Mg}{ }^{2+}-\mathrm{ATP}$ ase and $\mathrm{Na}^{+}-\mathrm{K}^{+}-\mathrm{AT}$ Pase is linear up to 80 minutes (Fig. 17). Consequently, calculation of enzyme activity, based on an incubation time of $60 \mathrm{minu}-$ 


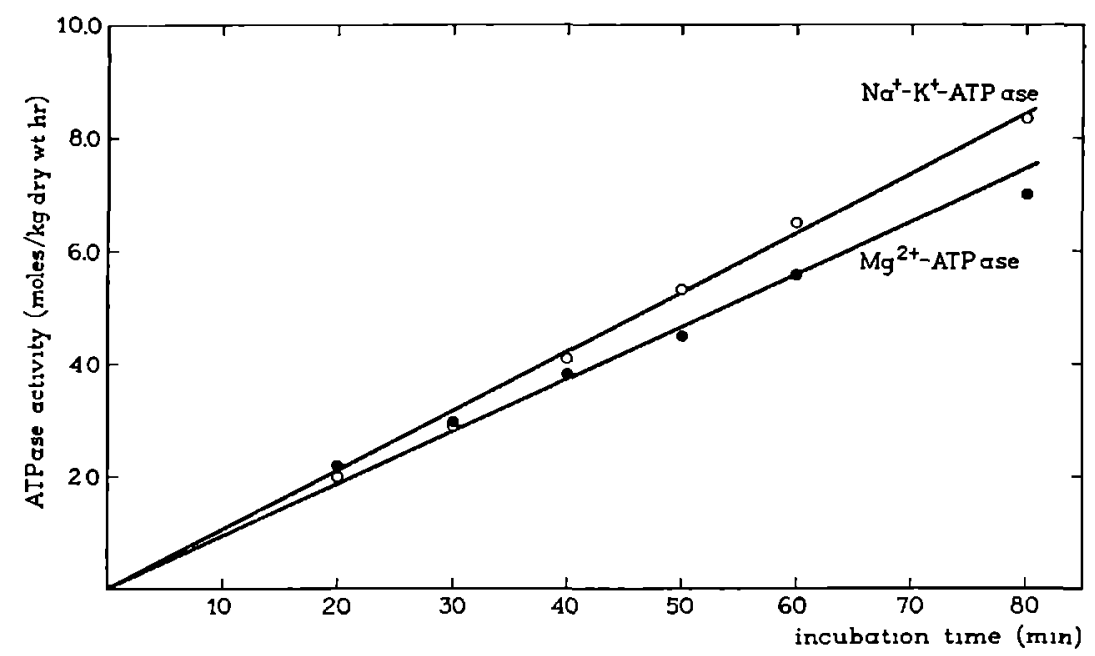

Fig. 17. ATPase activities in homogenates of gunea pig stria vascularis, determined in medium $A$ (complete) and $E$ (no $\mathrm{K}^{+}, 10^{-1} \mathrm{M}$ ouabain) after various incubation times. $\mathrm{Na}^{\top}-\mathrm{K}^{+}-\mathrm{ATP}$ ase activity $\mathrm{o}-\mathrm{o}, \mathrm{Mg}^{2+}$-ATPase activity

tes, will give a correct estimation of this activity.

The relative ATPase activities of the stria vascularis in the various substrate media are given in Table 6 . The four inhibitory media caused

Table 6

RELATIVE ATPase ACTIVITIES OF GUINEA PIG STRIA VASCULARIS HOMOGENATES IN VARIOUS SUBSTRATE MEDIA

Medium

A (complete)

B (no $\mathrm{K}^{-}$)

C $\left(\right.$ no $\left.\mathrm{Na}^{+}\right)$

D $\left(10^{-1} \mathrm{M}\right.$ ouabain $)$

$\mathrm{E}$ (no $\mathrm{K}^{+}, 10^{-4} \mathrm{M}$ ouabain)

Average for media B, C, D and E
$\%$

100

$44.2 \pm 1.9(22)$

$37.4 \pm 2.2$

$40.4 \pm 1.9(22)$

$40.5 \pm 1.8(22)$

$40.6 \pm 1.4$

Total ATPase activity in medium $\mathrm{A}$ is set at $100 \%$.

Relative activities in media $\mathrm{B}, \mathrm{C}, \mathrm{D}$, and $\mathrm{E}$ are given with standard errors and in parentheses number of determinations.

approximately the same degree of inhibition, indicating that the inhibited ATPase activity represents the $\mathrm{Na}^{+} \mathrm{K}^{+}-\mathrm{ATPase}$ activity. Medium $B$ gave slightly less inhibition than the other media. This is probably due to partial activation of the $\mathrm{Na}^{+}-\mathrm{K}^{+}-$ATPase by a small 
amount of tissue $\mathrm{K}^{+}$present in the medium during incubation, since the $\mathrm{K}_{\mathrm{m}}$ value for $\mathrm{K}^{+}$is only 0.9 ( $\mathrm{F}_{1 \mathrm{~g}} .20$ ). Medium $\mathrm{C}$ showed slightly more inhibition than the other media. This effect may be due to a slight $\mathrm{Na}^{+}$ dependence of the $\mathrm{Mg}^{2+}$-ATPase, as has also been observed in other tissues (Bonting et al., 1964 a; Bakkeren and Bonting, 1968).

Fig. 18 shows the effect of increasing the $\mathrm{Mg}^{2+}$ concentration from 0-6 $\mathrm{mM}$ in the media $\mathrm{A}$ and $\mathrm{E}$. Both $\mathrm{Na}^{+}-\mathrm{K}^{+}-\mathrm{ATPase}$ actuvity and

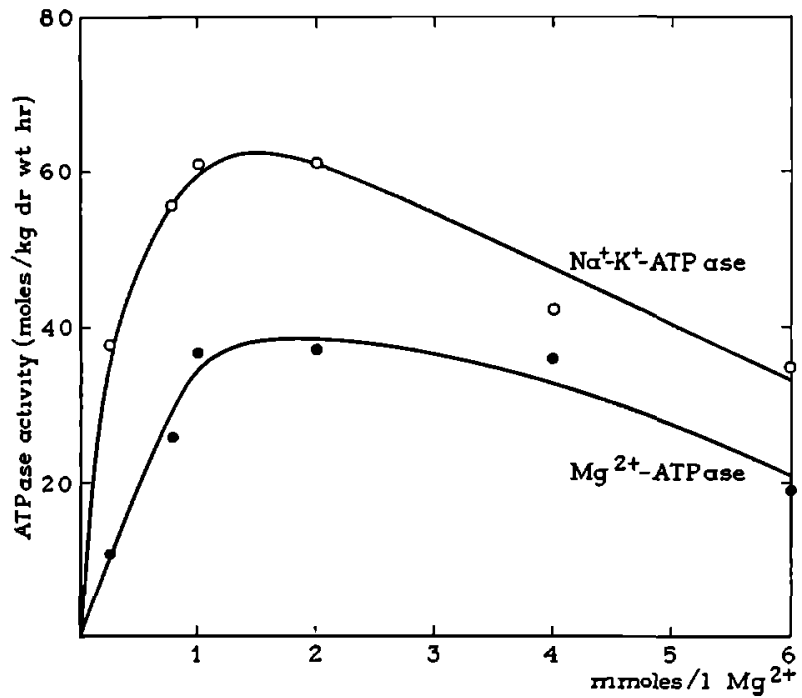

Fig. 18 Effect of $\mathrm{Mg}^{2+}$ concentration on $\mathrm{Na}^{+}-\mathrm{K}^{+}$-ATPase activity $\mathrm{o}-\mathrm{o}$ and $\mathrm{Mg}^{2+}$-ATPase activity - - in homogenates of guinea pig stria vascularis. Activities were measured in media $\mathrm{A}$ and $\mathrm{E}$ to which was added $\mathrm{MgCl}_{2}(0-6 \mathrm{mM})$. Medium $\mathrm{E}$ (no $\mathrm{K}^{+}, 10^{-1} \mathrm{M}$ ouabain) gave $\mathrm{Mg}^{2+}$-ATPase actuvity, while the difference between the activities in media $A$ (complete) and $E$ gave $\mathrm{Na}^{+}-\mathrm{K}^{+}-\mathrm{ATP}$ ase activity.

$\mathrm{Mg}^{2+}$-ATPase activities were maximal at 1-2 $\mathrm{mM} \mathrm{Mg}^{2+}$ present in the media at an ATP concentration of $2 \mathrm{mM}$ and were depressed at higher $\mathrm{Mg}^{2+}$ concentrations. No ATPase activity could be demonstrated in the absence of $\mathrm{Mg}^{2+}$.

The activation of the $\mathrm{Na}^{+}-\mathrm{K}^{+}-\mathrm{ATP}$ ase by $\mathrm{Na}^{+}$in the presence of $5 \mathrm{mM} \mathrm{K}^{+}$is given in Fig. 19. The activity was measured in medium $\mathrm{C}$ to which increasing amounts of $\mathrm{NaCl}$ were added $(0-150 \mathrm{mM})$. Maximal activity was reached at $10 \mathrm{mM} \mathrm{Na}{ }^{+}$. followed by a striking decrease between 10 and $20 \mathrm{mM}$; then the activity remained unchanged up to $150 \mathrm{mM}$. Half maximal activation occurred at $4,5 \mathrm{mM} \mathrm{Na} \mathrm{Na}^{+} / 1$. This value is somewhat lower than that for other tissues (Table 5).

Fig. 20 represents the $\mathrm{K}^{+}$activation curve of the $\mathrm{Na}^{+}-\mathrm{K}^{+}-\mathrm{ATPase}$ 


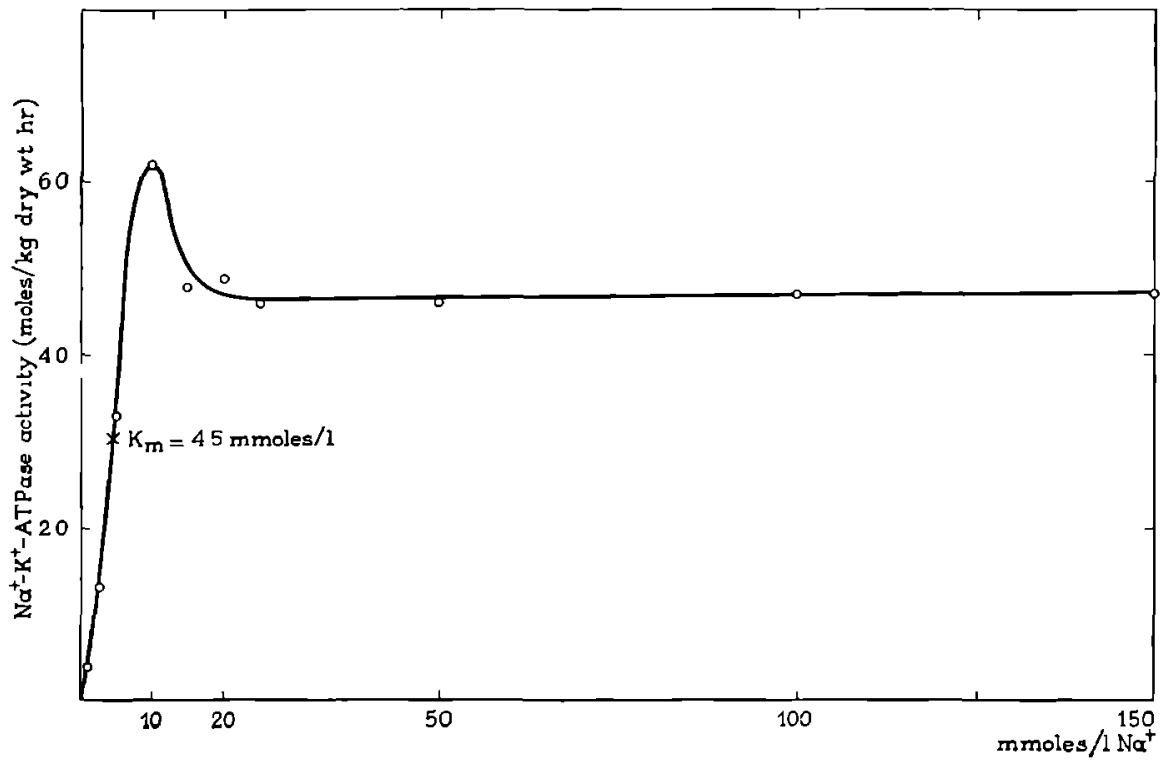

$F_{1 g} 19$ Effect of $\mathrm{Na}^{+}$concentration on $\mathrm{Na}^{+}-\mathrm{K}^{+}$-ATPase activity in homogenates of guinea pig stria vascularis Graded amounts of $\mathrm{NaCl}$ were added to medium $\mathrm{C}$ $\left(\right.$ no $\mathrm{Na}^{+}$), while the $\mathrm{K}^{+}$concentration was kept at $5 \mathrm{mM}$ Activity in medium $\mathrm{C}$ without added $\mathrm{NaCl}$ gave $\mathrm{Mg}^{2}+$-ATPase activity

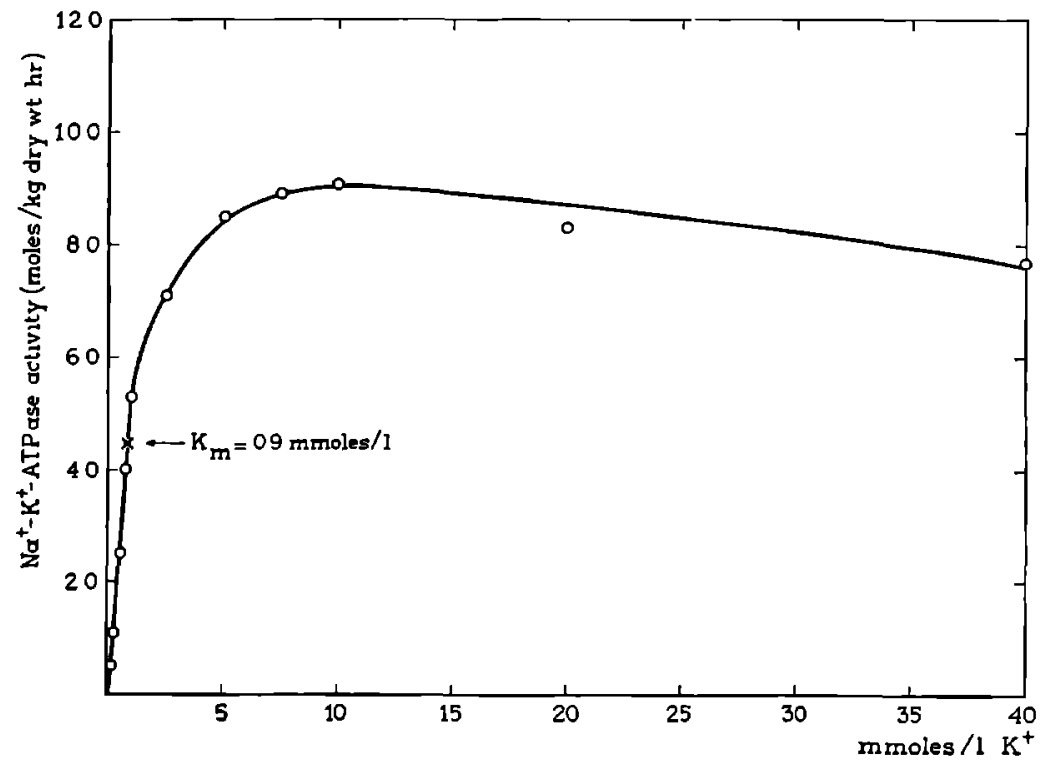

Fig 20 Effect of $\mathrm{K}^{+}$concentration on $\mathrm{Na}^{+}-\mathrm{K}^{+}-\mathrm{ATPase}$ activity in homogenates of guinea pig stria vascularis Graded amounts of $\mathrm{KCl}$ were added to medium $\mathrm{B}$ (no $\mathrm{K}^{+}$), while the $\mathrm{Na}^{+}$concentration was kept at $63 \mathrm{mM}$ Activity in medium $\mathrm{E}$ (no $\mathrm{K}^{+}$, $10^{-4} \mathrm{M}$ ouabain) gave $\mathrm{Mg}^{2+}$-ATPase activity. 
activity in the presence of $63 \mathrm{mM} \mathrm{Na}{ }^{+}$. This curve was obtained by measuring enzyme activity in medium $B$, containing various amounts of $\mathrm{K}^{+}(0-40 \mathrm{mM})$. Maximum activity was reached at $7.5 \mathrm{mM}$ and half maximal activation at $0.9 \mathrm{mM} \mathrm{K} \mathrm{K}^{+} / 1$. The activity at $5 \mathrm{mM} \mathrm{K}+$, routinely used in the various substrate media, is only slightly different from the maximal activation obtained at $7.5 \mathrm{mM} \mathrm{K}$. The values for potassium activation are in good agreement with those reported for other tissues (Table 5).

The $\mathrm{pH}$ optimum for $\mathrm{Na}^{+}-\mathrm{K}^{+}-\mathrm{ATP}$ ase $1 \mathrm{~s}$ at 7.3 and for $\mathrm{Mg}^{2+}$ ATPase at 87 as shown in Fig. 21. These curves were obtained by

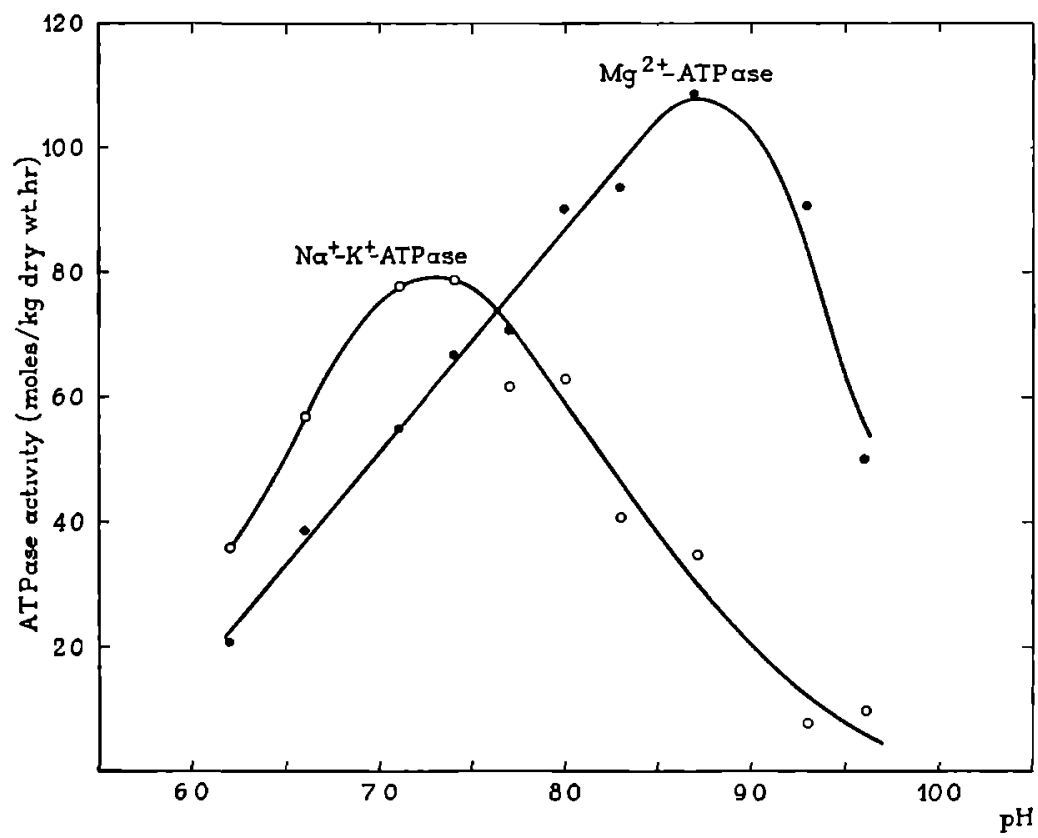

$F_{1 g} 21$ Effect of $\mathrm{pH}$ on $\mathrm{Na}^{+}-\mathrm{K}^{+}$-ATPase activity $\mathrm{o}-\mathrm{O}$ and $\mathrm{Mg}^{2+}$-ATPase activity - In homogenates of guinca pig stria vascularis The $\mathrm{pH}$ dependence was measured in media $A$ (complete) and $E$ (no $K^{\vdash}, 10^{-1} \mathrm{M}$ ouabain), prepared with Tris buffers in a $\mathrm{pH}$ range from $62-96$ The $\mathrm{Mg}^{2+}$-ATPase activity was measured in medium $\mathrm{E}$, while the $\mathrm{Na}^{+}-\mathrm{K}^{+}$-ATPase activity was calculated from the difference between activities in media $A$ and $E$

measuring enzyme activities in the media $A$ and $E$ prepared with Tris- $\mathrm{HCl}$ buffers in a $\mathrm{pH}$ range from 7.4 to 96 and with Tris-histidine buffers in a $\mathrm{pH}$ range from 6.2-7.4. These optima are close to the values found in several other tissues (Table 5).

The inhibitory effect of ouabain on the $\mathrm{Na}^{+}-\mathrm{K}^{+}-\mathrm{ATPase}$ activity is presented in Fig. 22. This curve was determıned by addıng ouabain in 


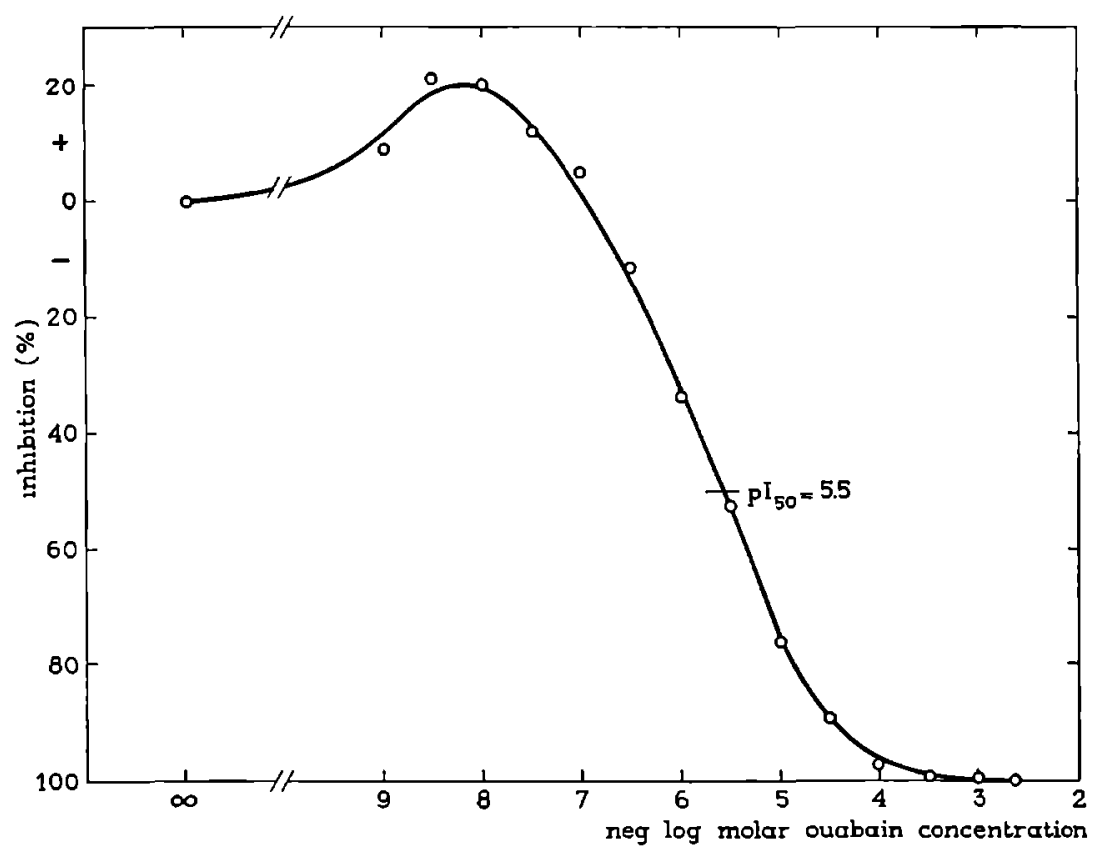

Fig. 22. Effect of ouabain on $\mathrm{Na}^{+}-\mathrm{K}^{+}-\mathrm{ATPase}$ activity in homogenates of guinea pıg stria vascularis. ATPase activity was determined in medium $A$ containing various amounts of ouabain $\left(10^{-1}-10^{-2} \mathrm{M}\right.$ ). The activity in medium $\mathrm{E}$ (no $\mathrm{K}^{+} \cdot 10^{-4} \mathrm{M}$ ouabain) was taken to represent $\mathrm{Mg}^{2+}$-ATPase alone. The $\mathrm{pI}$ iso is the negative logarithm of the molar oubain concentration causing $50 \%$ inhibition.

various concentrations $\left(10^{-2}-10^{-9} \mathrm{M}\right)$ to medium $A$. The activity in medium $\mathrm{E}$ was considered to represent only $\mathrm{Mg}^{2+} \mathrm{ATPase}$ activity. The negative logarithm of the half maximal inhibition concentration of ouabain was $\mathrm{pI}_{50}=5.5$, close to the value of 5.4 found for guinea pig intestine (Taylor, 1962). At very low ouabain concentrations (10-8 M) a stimulation of 20 (SE: 8 ) \% of the $\mathrm{Na}^{+}-\mathrm{K}^{+}-\mathrm{ATP}$ ase activity was found, just as in the chicken tegmentum vasculosum (Chapter VI). This biphasic effect on $\mathrm{Na}^{+}-\mathrm{K}^{+}-\mathrm{ATP}$ ase activity as well as on cation transport was also observed in the kidney (Palmer and Nechay, 1964). chorioid plexus (Oppelt and Palmer, 1966) and pancreas (Ridderstap and Bonting, $1969 \mathrm{~b}$ ).

3. Distribution of A TPase activities of the various cochlear structures

Since preliminary studies demonstrated the presence of a very high $\mathrm{Na}^{+}-\mathrm{K}^{+}-\mathrm{ATP}$ ase activity in the stria vascularis, we made a systematic study of the distribution of this enzyme system in the cochlear structu- 
res, especially in those which might be involved in cochlear cation transport. The dissection procedures used for isolating the various tissues have been described in Chapter V, 2.

The distribution of enzyme activities in the cochlear structures is presented in Table 7 , and for the $\mathrm{Na}^{+}-\mathrm{K}^{+}-\mathrm{ATP}$ ase activity alone in a

Table 7

ATPase ACTIVITIES IN HOMOGENATES OF THE VARIOUS COCHLEAR STRUCTURES OF THE GUINEA. PIG

\begin{tabular}{|c|c|c|c|c|}
\hline \multirow[b]{2}{*}{ Structure } & \multicolumn{2}{|c|}{$\mathrm{Na}^{+}-\mathrm{K}^{+}-\mathrm{ATPase}$} & \multirow{2}{*}{$\begin{array}{c}\mathrm{Mg}^{2+} \text { ATPase } \\
\text { moles/kg } \\
\text { dry wt/hr }\end{array}$} & \multirow{2}{*}{$\begin{array}{c}\text { Mean } \\
\text { activity of } \\
\text { turn No }\end{array}$} \\
\hline & $\begin{array}{l}\text { moles } / \mathrm{kg} \\
\text { dry wt/hr }\end{array}$ & $\begin{array}{l}\% \text { of total } \\
\text { ATPase }\end{array}$ & & \\
\hline Stria vascularıs & $80 \pm 043(16)$ & $59 \pm 1$ & $56 \pm 041$ & $1,2,3$ \\
\hline Lig spirale & & & & \\
\hline (A) behind stria vascularis & $04+009$ & $50 \pm 8$ & $04 \pm 009$ & 2,3 \\
\hline $\begin{array}{l}\text { (B) comprising prominentia } \\
\text { spiralis and sulcus externus }\end{array}$ & $16 \pm 039$ & $55 \pm 6$ & $13 \pm 043$ & 2,3 \\
\hline (C) bordering scala tympanı & $04 \pm 007$ & $40 \pm 7$ & $06 \pm 007$ & 2,3 \\
\hline Reissner's membrane & $04 \pm 006(12)$ & $30 \pm 4$ & $09 \pm 010$ & $1,2,3,4$ \\
\hline Organ of Cort1 & $05 \pm 027$ & $15 \pm 6$ & $28 \pm 079$ & 2,3 \\
\hline
\end{tabular}

Means with SE and in parentheses number of determınations

schematic cross section of the cochlea ( $F_{1 g}$. 23). In the last column of Table 7 the numbers refer to the turns from which the various tissues were obtaned. The $\mathrm{Na}^{+}-\mathrm{K}^{+}-\mathrm{ATP}$ ase activity of the stria vascularis ( 8.0 moles $/ \mathrm{kg}$ dry wt $/ \mathrm{hr}$ ) is extremely high and forms $59 \%$ of the total ATPase activity. The activity in this structure is about 12 times as high as the average activity in the ligamentum spirale, Reissner's membrane and organ of Cort1, which range from $0.4-1.6$ moles $/ \mathrm{kg}$ dry wt/hr.

The ATPase activities of the ligamentum spirale appeared to be rather high, contrary to what could be expected from its connective tissue structure. In an attempt to localise this enzyme activity we divided the ligamentum spirale longitudinally into three parts and assayed them separately for ATPase activity. The results are represented in Table 7 and Fig. 23. The highest activity was found in part B of the ligamentum spirale, comprising the prominentia spiralis and sulcus externus. Histological sections of part B made after dissection showed that epithelial cells of the prominentia spiralis were absent. 


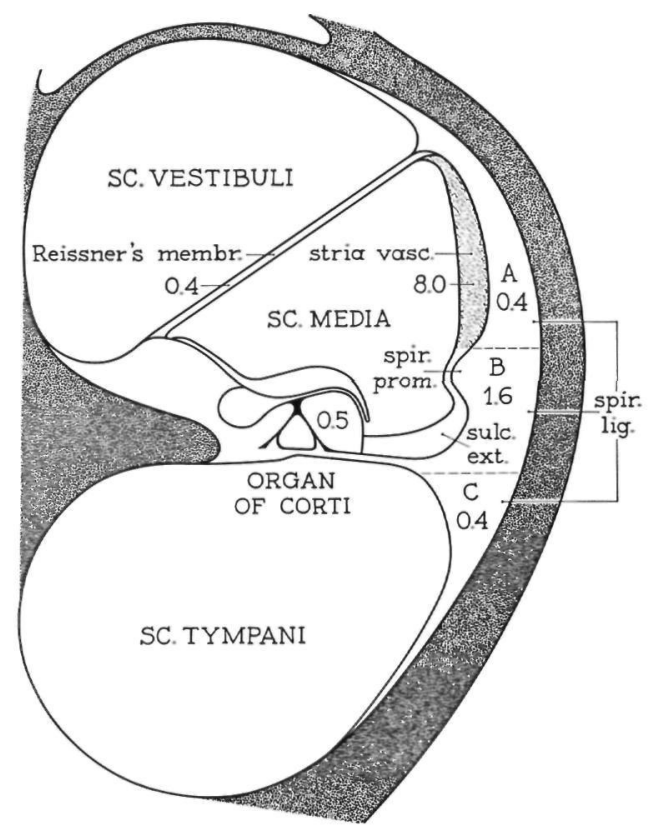

Fig. 23. Schematic cross section of the cochlea. $\mathrm{Na}^{+}-\mathrm{K}^{+}-\mathrm{ATP}$ ase activities in moles $/ \mathrm{kg}$ dry wt $/ \mathrm{hr}$ are indicated by the numbers in the various structures.

They were presumably removed together with the stria vascularis, which was dissected from the ligamentum spirale before dividing it into three parts. Thus, the enzyme activity of part B is probably mainly present in the sulcus externus epithelium and the stroma cells of the ligamentum spirale.

In order to ascertain possible differences in ATPase activities in the various cochlear turns, we have determined enzyme activities in the stria vascularis, ligamentum spirale and Reissner's membrane, obtained from individual turns. The bony connection between cochlea and middle ear wall was taken as the boundary line between the turns. The $\mathrm{Na}^{+}-\mathrm{K}^{+}-\mathrm{ATP}$ ase and $\mathrm{Mg}^{2+}{ }_{-}$ATPase activities of the stria vascularis in each turn are given in Table 8 , and the total dry weight of this structure in each turn is included. There is a distinct decrease in both ATPase activities from base to apex. The ratio between $\mathrm{Na}^{+} \mathrm{K}^{+}$ATPase and $\mathrm{Mg}^{2+}$ ATPase remained about the same. In these experiments the final tissue concentrations in the incubation media for third and fourth turns were considerably lower than for the first and second turns, ranging from 0.2 to $0.6 \mu \mathrm{g} / 10 \mu \mathrm{l}$. In order to exclude the possibility that this might cause the decrease in ATPase activities from first to fourth turn, we determined ATPase activities for tissue concen- 
Table 8

ATPase ACTIVITIES IN HOMOGENATES OF GUINEA PIG STRIA VASCULARIS OF VARIOUS COCHLEAR TURNS

\begin{tabular}{|c|c|c|c|c|}
\hline \multirow[b]{2}{*}{ Turn no. } & \multicolumn{2}{|c|}{$\mathrm{Na}^{+}-\mathrm{K}^{+}-\mathrm{ATPase}$} & \multirow{2}{*}{$\begin{array}{c}\mathrm{Mg}^{2+}-\mathrm{ATI}^{\mathrm{2}} \mathrm{ase} \\
\text { moles } / \mathrm{kg} \\
\mathrm{dry} \mathrm{wt} / \mathrm{hr}\end{array}$} & \multirow{2}{*}{$\begin{array}{l}\text { Total dry } \\
\text { weight of } \\
\text { stria vasc. } \\
(\mu \mathrm{g})\end{array}$} \\
\hline & $\begin{array}{l}\text { moles/kg } \\
\text { dry wt/hr }\end{array}$ & $\begin{array}{c}\% \text { of total } \\
\text { ATPase }\end{array}$ & & \\
\hline 1 & $64 \pm 040$ & $56 \pm 3$ & $5.0 \pm 0.46$ & 13 \\
\hline 2 & $7.0 \pm 0.88(7)$ & $62 \pm 4$ & $4.3 \pm 035$ & 12 \\
\hline 3 & $4.6 \pm 070$ & $58 \pm 6$ & $34 \pm 058$ & 7 \\
\hline 4 & $4.4 \pm 0.55(5)$ & $59 \pm 2$ & $3.1 \pm 0.37$ & 3 \\
\hline
\end{tabular}

Means with SE and in parentheses number of determinations. Basal turn is turn $n=1$, apical turn is turn no. 4.

trations varying from 0.1 to $0.7 \mu \mathrm{g}$ per $10 \mu \mathrm{l}$ medium. The results are shown in Fig. 27. The linearity of these curves demonstrates that the decrease in enzyme actıvity from base to apex must be real. This effect

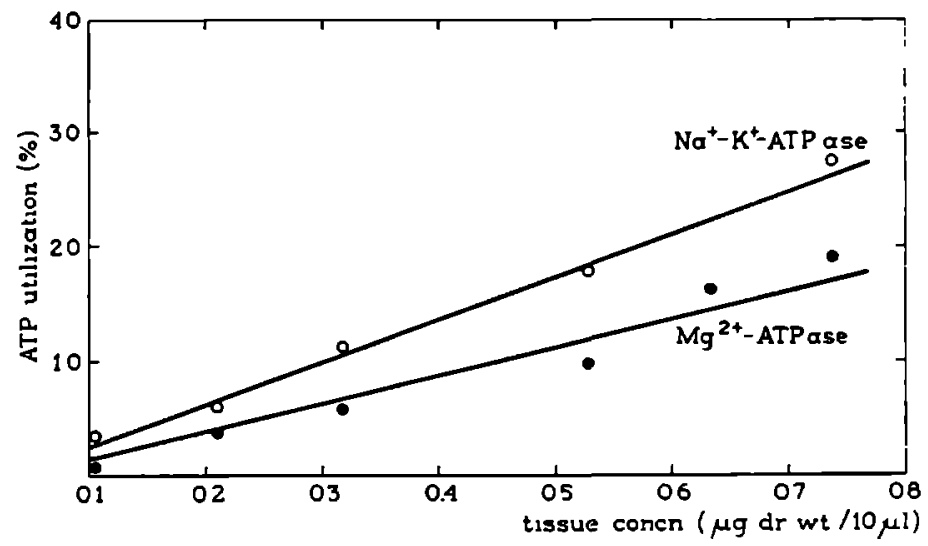

Fig 24. ATP utilisation in percent of total ATP present in the incubation medium by ATPase activities in homogenates of guinea pig stria vascularis at various tissue concentrations. Activities were determined in medium $A$ (complete) and $E$ (no $K^{+}$, $10^{-1} \mathrm{M}$ ouabain). $\mathrm{Na}^{+}-\mathrm{K}^{+}$-ATPase activity $\mathrm{o}-\mathrm{o}, \mathrm{Mg}^{2+}$-ATPase activity

is much more pronounced when the total dry weight of the stria vascularis of each turn, given in Table 8 , is taken into account. This gives a $\mathrm{Na}^{+}-\mathrm{K}^{+}-\mathrm{ATP}$ ase activity expressed in nanomoles $/ \mathrm{kg} \mathrm{dry} \mathrm{wt} / \mathrm{hr}$ of 83 for the first turn, of 84 for the second turn, of 32 for the third turn and of 13 for the fourth turn. 
This decrease in enzyme activity could also be demonstrated for the ligamentum spirale of the various turns, as shown in Table 9. It was difficult to obtain ligamentum spirale of the first turn without adhering bone. Since bone fragments lead to high endogenous phosphate con-

Table 9

ATPase ACTIVITIES IN HOMOGENATES OF GUINEA PIG LIGAMENTUM SPIRALE OF VARIOUS COCHLEAR TURNS

\begin{tabular}{|c|c|c|c|}
\hline \multirow[b]{2}{*}{ Turn no. } & \multicolumn{2}{|c|}{$\mathrm{Na}^{+}-\mathrm{K}^{+}-\mathrm{ATPase}$} & \multirow{2}{*}{$\begin{array}{c}\mathrm{Mg}^{2+} \text {-ATPase } \\
\text { moles/kg } \\
\text { dry wt/hr }\end{array}$} \\
\hline & $\begin{array}{l}\text { moles/kg } \\
\text { dry wt/hr }\end{array}$ & $\begin{array}{c}\% \text { of total } \\
\text { ATPase }\end{array}$ & \\
\hline 2 & $15 \pm 018$ & $52 \pm 2$ & $14 \pm 017$ \\
\hline 3 & $08 \pm 009$ (4) & $38=2$ & $13 \pm 013$ \\
\hline 4 & $07 \pm 007$ & 44 上 1 & $09 \pm 012$ \\
\hline
\end{tabular}

Means with SE and in parentheses number of determinations No reliable data could be obtaned for the basal turn (no 1)

centrations and incorrect weight determinations, no data on ATPase activities are given for this turn In one experiment in which fragments of Reissner's membrane completely free of adhering dried lymph could be assayed separately for each turn, a similar decrease in enzyme act1vity was observed.

The absolute ATPase activity in Table 7 for the stria vascularis dissected in toto is $22 \%$ higher than the sum of the activities of the separate turns listed in Table 8 . This is probably due to a slight loss of activity during the extra time needed for dissection of the turns separately, or to a slight loss of tissue. Since the fourth and the third turns were always isolated first, this loss should have primarily affected the results for the first and second turns. Hence this would tend to make the real difference between these turns and the third and fourth turns even greater The enzyme activities for the organ of Cortı and Reissner's membrane should not be influenced by the above-mentioned effect, because these structures were dissected from whole cochlea that were lyophilised immediately after decapitation as described in Chapter V, 2.

4. Discussion and conclusions

The data in Tables 6 and 7 and Figs. 18 to 23 demonstrate the presence of a $\mathrm{Na}^{+}-\mathrm{K}^{+}-$ATPase system in the guinea pig inner ear similar to that described by Skou $(1957,1960)$ in crab nerve, by Post et al. 
(1960) in erythrocytes and by Bonting et al. (1961 a, 1962) in a great number of tissues of various anımal species.

The properties of this $\mathrm{Na}^{+}-\mathrm{K}^{+}$-ATPase activity in the guinea pig cochlea appeared to be quite similar to those found in the chicken inner ear (Chapter VI) and to those in many other tissues in which active cation transport occurs and in which a good agreement has been demonstrated between the properties of the enzyme system and the cation transport system (Post et al., 1960. Dunham and Glynn, 1961. Bonting and Caravaggıo. 1963. Bontıng and Canady, 1964). The stımulation by $\mathrm{Na}^{+}, \mathrm{K}^{+}$, and $\mathrm{Mg}^{2+}$ and the inhibition by ouabain of the $\mathrm{Na}^{+}-\mathrm{K}^{+}-$ ATPase activity is much more pronounced than reported by Inuma (1967) for the stria vascularis and the ligamentum spirale together. These differences are probably due to less sutable methods used by the latter investigator e.g. the use of non-homogenised freshly dissected tissue samples without lyophilisation.

As demonstrated in Table 7 and $\mathrm{F}_{1 \mathrm{~g}} .23$ the $\mathrm{Na}^{+}-\mathrm{K}^{+}-\mathrm{ATPase}$ act1vity of the stria vascularis, constituting $59 \%$ of the total ATPase act1vity is far higher than in any of the other cochlear structures. This was also true for enzymes involved in oxidative metabolism (Vosteen, 1961; Spoendlın and Balogh, 1963; Nakat and Hildıng, 1968 a), and for the $\mathrm{O}_{2}$ consumption of this structure, which is higher than that of kidney and brain tissue (Chou and Rodgers. 1962). The high oxidative metabolism of the stria vascularis presumably supplies the large amount of ATP required by the $\mathrm{Na}^{+}-\mathrm{K}^{+}$-ATPase system. Such a high $\mathrm{Na}^{+}-\mathrm{K}^{+}$ATPase activity, as was also found in the tegmentum vasculosum of the chicken cochlea (Chapter VI), is typical for secretory tissues like kidney (Bonting et al., 1961 a; Bonting et al., 1962), rectal gland of elasmobranchs (Bontıng, 1966). nasal gland of marine birds (Hokın, 1963; Bonting et al., 1964 a) and choriord plexus (Vates et al., 1964) and for excitatory tissues like the electroplax of the electric eel (Bonting et al., 1961 a) and brain tissue (Bonting et al., 1962). An electronmicroscopic study has shown the ATPase activity to be localised on the cell membranes of the marginal cells of the stria vascularis and in the basement membranes of the capillaries (Nakat and Hilding, 1966).

There is a clear decrease for both ATPase activities from first to fourth turn of the cochlea, not only in the stria vascularis but also in the ligamentum spirale and probably in Reissner's membrane. Tables 8 and 9. This phenomenon has also been demonstrated for lactic and malic dehydrogenase (Kurschner, 1968) and for the $\mathrm{O}_{2}$ consumption of the stria vascularis (Meyer zum Gottesberge et al.. 1965) and of the whole membranous structure (Mızukoshı and Daly, 1967). Furthermore the ERP has been shown to decrease from basal to apical turn (Mirashy et al., 1958 b). In contrast linuma (1967) reported a more irregular distribution over the various turns for the $\mathrm{Na}^{+}-\mathrm{K}^{+}$-ATPase 
activity of the stria vascularis-ligamentum spirale complex with a tendency to increase towards the apex, although for the phosphatase activities in the same complex an increase in activity from base to apex was found (Iınuma and Daly, 1968). In our opınıon Inuma's deviating results may be due to the use of non-homogenised and non-lyophilised fresh tissue causing difficulties in substrate penetration (Bonting and Rosenthal, 1960). Because the mass of this tissue complex is much larger for the basal than for the apical turns, the effect should be more pronounced in the basal turns.

The relatively high $\mathrm{Na}^{+}-\mathrm{K}^{+}-\mathrm{ATP}$ ase activity in part $\mathrm{B}$ of the ligamentum spirale (Table 7, Fig 23) is noteworthy. In view of the absence of epithelial cells in the dissected part B of the prominentia spiralis the enzyme activity can only be localised in the sulcus externus and in the stroma cells behind the epithelium. This may be in accordance with the presence of a high activity of enzymes involved in oxidative metabolism in this region (Vosteen, 1961; Spoendlın and Balogh, 1963. Ishiı and Nomura, 1968). Moreover these stroma cells show extensive infoldings of the cell membrane and many vacuoles (Spoendlin, 1967 a, von Ilberg et al, 1968) indicating that they are involved in fluid transport. A resorptive function of these cells has been demonstrated by von Ilberg et al. (1968). Therefore it may be concluded that this structure seems to be involved in cochlear fluid circulation.

The $\mathrm{Na}^{+}-\mathrm{K}^{+}-\mathrm{AT}$ Pase activities in the organ of Cort1, Reissner's membrane and other parts of the ligamentum spirale are very low in comparison to the stria vascularis (Table 7, Fig. 23). The organ of Cortı has a high $\mathrm{Mg}^{2+}$-ATPase activity. Nakaı and Hilding (1967) demonstrated in this structure histochemically the presence of ATPase activity along the cell membranes. Moreover, an active metabolism has been demonstrated in this organ (Vosteen, 1961; Spoendlin and Balogh. 1963; Matschinsky and Thalmann, 1967) Since the $\mathrm{Mg}^{2+}$ ATPase system does not function in cation transport, the energy released by this enzyme in the organ of Corti must be used for other purposes than cation transport, probably in the perception and transduction of acoustic stımuli.

In view of its high $\mathrm{Na}^{+}-\mathrm{K}^{+}-\mathrm{ATP}$ ase activity the stria vascularis would appear to be the site of the cation pump, which maintains the ionic concentration gradients between endolymph and perilymph or blood ( $F_{1 g}$. 23). The assumption by Rauch (1964) that transport of $\mathrm{K}^{+}$from perilymph to endolymph would occur through Reissner's membrane must be considered highly unlikely in view of the low $\mathrm{Na}^{+}-\mathrm{K}^{+}$ATPase activity of this structure. This activity is low on a weight basis, but even more so on an absolute basis. The ratio of the dry weights of stria vascularis and Reissner's membrane in the entire cochlea is approxi- 
mately 31 , hence the ratio of total $\mathrm{Na}^{+}-\mathrm{K}^{+}-\mathrm{ATP}$ ase activities in these structures is $68 \mathrm{I}$ This consideration leads us to the conclusion that the contribution of Reissner's membrane to the active cation transport can only be very minor. Additional arguments for this conclusion can be derived from the fact that the membrane is avascular and has a very high electrical resistance (Johnstone et al , 1966).

The transport of $\mathrm{K}^{+}$from the perilymph in the scala vestibuli to the endolymph, observed by Rauch (1964), could take place through the ligamentum spirale, through which perilymph can easily circulate (Tonndorf et al., 1962; von Ilberg. 1968 b). After arriving in the stria vascularis it would be actively secreted into the endolymph, while $\mathrm{Na}^{+}$ would be actively removed from the endolymph by the same structure. An argument in favour of this supposition is the fact that in Rauch's experiments the ligamentum spirale and the stria vascularis showed a high isotope content, even when $42 \mathrm{~K}^{+}$was injected immediately after interruption of the blood supply. This confirms that $+2 \mathrm{~K}^{+}$can easily diffuse from scala vestubul to stria vascularis. In this connection it seems unlikely that Reissner's membrane should have nearly the same $\mathrm{QO}_{2}$ as the stria vascularis (Chou, 1963), which is highly vascularised and has a far higher number of mitochondria in its cells than Reissner's membrane (Figs. 4 and 5). Recently Rauch (personal communication) has found a much lower $\mathrm{O}_{2}$ consumption of this membrane than reported by Chou (1963). The $\mathrm{Na}^{+}-\mathrm{K}^{+}-\mathrm{ATP}$ ase system in the stria vascularis would therefore, appear to be the system which actively regulates the characteristic cation composition of the endolymph. The contribution of the other cochlear structures, judging from the $\mathrm{Na}^{+}-\mathrm{K}^{+}-$ ATPase distribution, can be considered to be negligible. In particular, such a role seems highly unlikely for Reissner's membrane. This conclusion would be in harmony with the hypothesis of Naftalin and Harrison (1958). These authors assume that there is only a passive leakage of $\mathrm{Na}^{+}$into and of $\mathrm{K}^{+}$out of the endolymph through Reissner's membrane From the endolymph $\mathrm{Na}^{+}$would be removed actively, in exchange for $\mathrm{K}^{+}$, by a $\mathrm{Na}^{+}$pump in the stria vascularis, leading to the typical ionic composition of the endolymph

In view of the strong evidence for a primary function of this enzyme system in cation transport in nerve (Baker, 1963, Baker and Connelly, 1966. Baker et al., 1969) and muscle (Corrie and Bontıng, 1966) as well as in the formation of cerebrospinal fluid (Vates et al., 1964), aqueous humor (Bonting and Becker, 1964) and pancreatic juice (Ridderstap and Bonting, $1969 \mathrm{a}, \mathrm{b})$, it would seem to be a reasonable assumption, that the $\mathrm{Na}^{+}-\mathrm{K}^{+}-\mathrm{ATP}$ ase system in the stria vascularis may play the role of the cation pump in the endolymph formation. 


\section{THE EFFECT OF OUABAIN ON THE COCHLEAR POTENTIALS OF THE GUINEA PIG}

\section{Introduction}

Both the cochlear endolymphatic resting potential (ERP) and the cochlear microphonic potential (CMP) have been shown to be dependent on the ionic composition of the cochlear fluids especially the high $\mathrm{K}^{+}$and low $\mathrm{Na}^{+}$concentration of the endolymph (Chapter III). These potentials are also dependent on oxidative metabolism, suggesting the involvement of oxidative metabolism in the maintenance of the typical intracellular-like ionic composition of the endolymph. In the previous chapters we reported the presence of a very high $\mathrm{Na}^{+}-\mathrm{K}^{+}$activated ATPase activity in the tissues of the inner ear From these experiments it was concluded that this enzyme system is primarily localised in the stria vascularis of the guinea pig and in the analogous tegmentum vasculosum of the chicken, and that it represents most likely the cation pump responsible for the ionic composition of the endolymph

The possible dependence of the cochlear potentials on the functioning of the $\mathrm{Na}^{+}-\mathrm{K}^{-}$-ATPase system was investigated by perfusing the perilymphatic space of the cochlea with Ringer solution containing ouabain, a specific inhibitor of the $\mathrm{Na}^{+} \mathrm{K}^{+}-\mathrm{ATP}$ ase system. The cochlear potentials were recorded simultaneously The effect of ouabain was studied both on the ERP and on the CMP, which is elicited by acoustic stimulation.

An attempt to study these potentials in the chicken inner ear was unsuccessful Although we succeeded after careful surgery to measure the CMP with a wire electrode placed on the round window, it was found to be impossible to perfuse the perilymphatic space without severely damaging the inner ear. This was concluded from the large decrease in the CMP immediately after opening the perilymphatic space. The guinea pig, which has frequently been used for electrophysiological studies on the inner ear, was more suitable for this purpose. In this animal the perilymphatic space could be opened and perfused with normal Ringer's solution without affecting the cochlear potentials, as previously reported by several authors (Tasakı et al., 1954: Honrubia et al., 1965, Konishı and Kelsey, 1968 a b) 
It has been shown (Rauch, 1964) that ${ }^{42} \mathrm{~K}^{+}$introduced into the scala vestibuli is quickly transported to the endolymph, while $42 \mathrm{~K}^{+}$injected into the scala tympani, reaches the endolymph much slower and to a much smaller extent. This indicates that the cation transport-system is more easily reached from the scala vestibul than from the scala tympanı. Therefore we chose the scala vestibulı for perfusion. Since the effect of ouabain on the CMP and the ERP had to be studied in separate experiments, we perfused in both cases the same region of the scala vestibuli, and placed the measuring electrodes in the same area (Fig. 11). Continuous removal of the outflowing perfusate was applied in order to avold non-specific effects on heart frequency and respiration.

\section{Cochlear Microphonic Potential}

Because the CMP is generated in the basal turns, both by high and low sound frequencies, and in the apical turns only by low frequencies ( $\mathrm{Ta}$ sak1, and Fernández, 1952), we perfused the first and second turn in order to be able to record the effects of ouabain for a wide frequency range. Moreover, because of their smaller dimensions the structures of the apical turns are damaged more easily than those of the basal turns.

In preliminary experiments the CMP was recorded immediately before and at various times after perfusing the scala vestibuli for three minutes with about $150 \mu$ l Ringer's solution containing 10-2 $\mathrm{M}$ ouabain. Sound was administered by a loudspeaker situated in the experimental room, and driven by a beat frequency oscillator. Sound pressure was measured with a probe microphone placed near the head of the animal.

The results of a typical experiment are shown in Fig. 25. The CMP was strongly depressed, maximal decrease being obtained 20 minutes after ouabain application. Recovery to nearly normal values was found two hours after ouabain perfusion. This recovery, although variable in degree, was frequently found after short term perfusions. It is probably due to washing out of ouabain by the continuous outflow of perilymph through the holes in the bony capsule which was visually observed

Because of the limited frequency range, the considerable variation in intensity over the frequency range offered (ranging from 50 to $90 \mathrm{~dB}$ ) and the poor quality of the sound produced by this system, all further experiments were carried out with the equipment described in Chapter $V$. 3. In this method sound was directly administered to the tympanic membrane. Thus a possible change in sound transmission by partial occlusion of the external auditory meatus during the experiment was avorded. Moreover, a constant sound pressure level of $80 \mathrm{~dB}$ for a frequency range from 500 to $16000 \mathrm{cps}$ could be obtained. The sound stımulus consisted of contınuous pure tones at 10 different frequencies in the frequency range of 500-8000 cps. In addition a continuous per- 


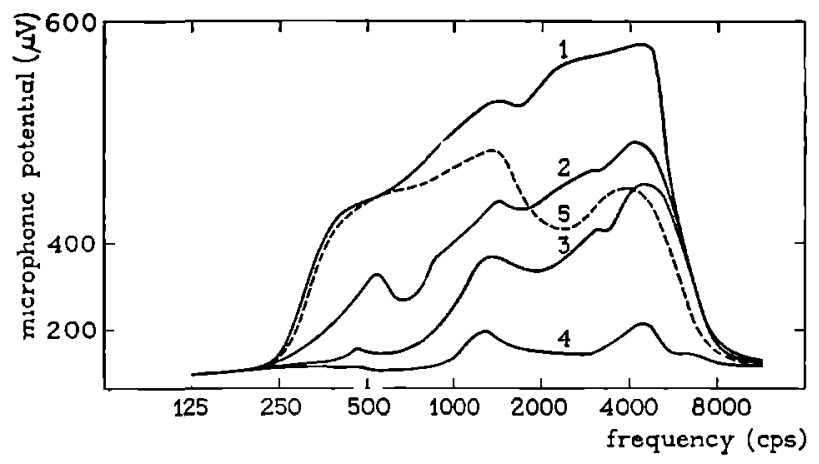

Fig. 25. Amplitude of the CMP at various frequencies before and after perfusing the scala vestibulı with about $150 \mu$ l Ringer's solution, containing $10^{-2} \mathrm{M}$ ouabain, for 3 minutes. 1. Before perfusion. 2. 3 minutes after perfusion. 3. 10 minutes after perfusion. 4. 20 minutes after perfusion. 5. 120 minutes after perfusion. The sound pressure varied from $50-90 \mathrm{~dB}$ in the frequency range of $500-6000 \mathrm{cps}$.

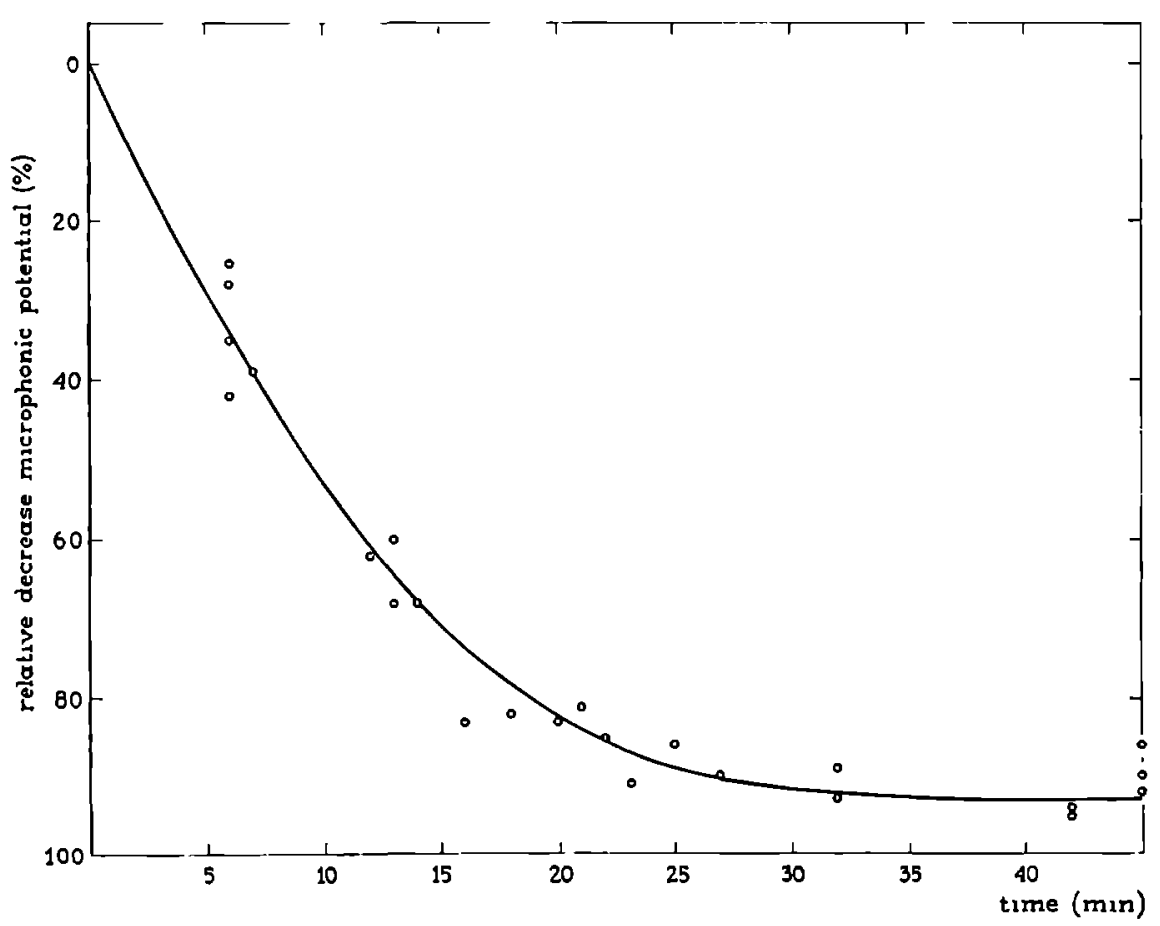

$F_{1}$ f. 26. Time course of relative decrease of the CMP, expressed in percentage of the original CMP value, upon continuous perlusion of the scala vestıbulı with $10^{-3} \mathrm{M}$ ouabain in Ringer's solution. Each point represents the mean value from five experiments, averaged for ten frequencies in the range of 500-8000 cps, intensity $80 \mathrm{~dB}$. 
fusing system ( $10 \mu \mathrm{l} / \mathrm{min})$ was used, which permitted us to observe the effect of known and constant concentrations of ouabain.

The tendons of the middle ear muscles, musculus tensor tympanı and musculus stapedius, attached to respectively malleus and stapes, were severed ( $\left.F_{1 g} 9\right)$ in order to eliminate changes in sound transmission to the inner ear, which might occur from an effect of outflowing ouabain on muscular activity Thus, a possible cause of unspecific changes in the CMP was avoided. Fig. 26 shows the time course for the decrease in the CMP, expressed in percentage of the original CMP value, upon perfusing the scala vestibuli for 45 min. with Ringer's solution containing 10-3 $\mathrm{M}$ ouabain. Each point represents the mean value from 5 experiments, averaged for ten frequencies in the range of 500 $8000 \mathrm{cps}$. The amplitude of the CMP. measured directly after inserting

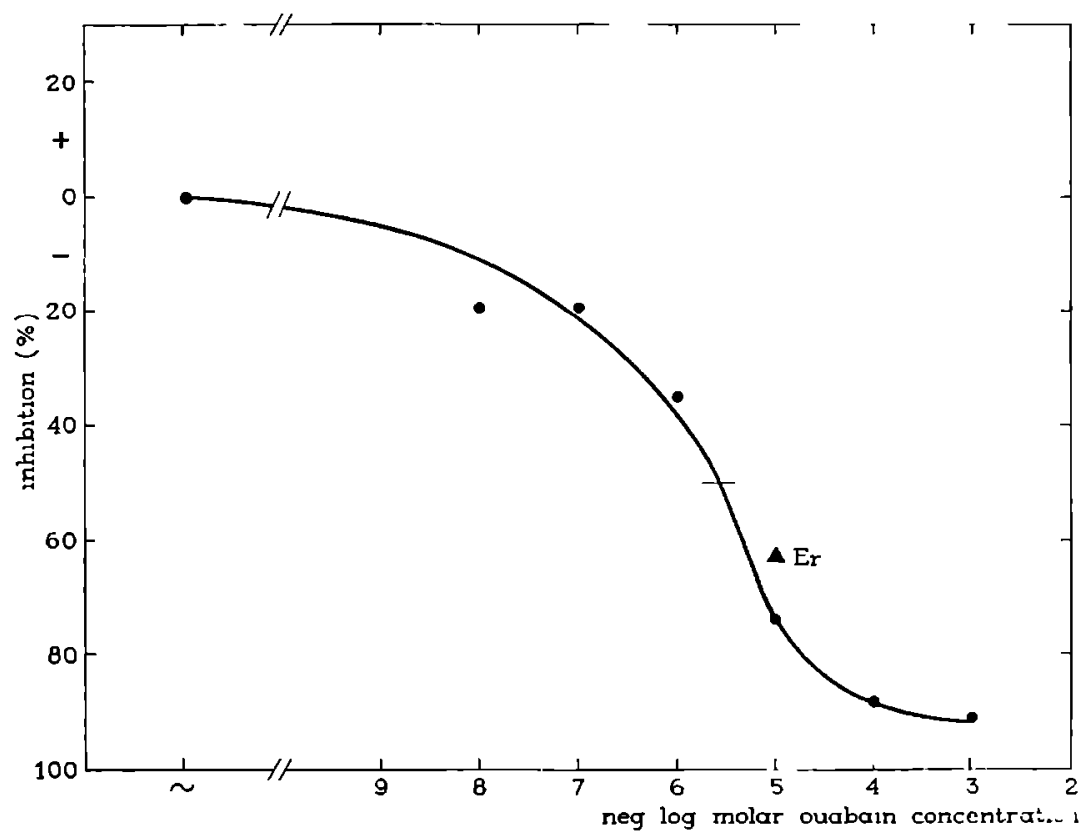

Fig 27 Effect on CMP of continuous perfusion of the scala vestibuli with Ringer $s$ solution and Ringer containing various amounts of ouaban $\left(10^{-8-10}{ }^{\prime} \mathrm{M}\right)$ or $10^{-5} \mathrm{M}$ erythrophleine, $\Delta \mathrm{E}_{\mathrm{r}}$, during 45 minutes Each point represents the mean value from five experiments, averaged for ten frequencies in the range of $5008000 \mathrm{cps}$, intensity $80 \mathrm{~dB}$ The pI ro for ouabain is 55

the pipet and before starting the perfusion, was set at $100 \%$. Maximal inhibition (90\%) was reached after 30 minutes, while no further decrease occurred upon continued perfusion. No significant difference was observed in the inhibition of the CMP at various frequencies. 
After perfusion for about 45 minutes an inhibition was observed of 88 (SE: 2.3 ) $\%$ at $500 \mathrm{cps}$. of 89 (SE: 3.3) \% at $4000 \mathrm{cps}$ and of 88 (SE: 2.7$) \%$ at $8000 \mathrm{cps}$. The persistence for several hours of about $10 \%$ of the original amplitude has also been shown after prolonged anoxemia (Davis, 1957).

Fig. 27 shows the effect on the CMP of perfusion for 45 minutes with normal Ringer's solution and Ringer's solution containing ouabain $\left(10^{-3} \mathrm{M}-10^{-8} \mathrm{M}\right)$ or erythrophleine $10^{-5} \mathrm{M}$. Maximal inhibition was obtained at $10^{-3} \mathrm{M}$ ouabain. The negative logarithm of the half maximal inhibition concentration $\left(\mathrm{pI}_{50}\right)$ was 5.5 . The effect of $10^{-5} \mathrm{M}$ erythrophleine on the CMP was only slightly different from that of $10^{-5} \mathrm{M}$ ouabain. This is in good agreement with the inhibitory effect of erythrophleine on the $\mathrm{Na}^{+}-\mathrm{K}^{+}$-ATPase activity (Bonting et al., $1964 \mathrm{~b}$ ).

\section{Endolymphatic Resting Potential}

The endolymphatic resting potential was measured by introducing a glass capillary electrode, filled with $150 \mathrm{mM} \mathrm{KCl}$, into the scala media as described in Chapter $\mathrm{V}, 3$. The electrode resistance, measured in a solution approximating endolymph (147 $\mathrm{mM} \mathrm{KCl}$ and $3 \mathrm{mM} \mathrm{NaCl})$. was always less than $5 \mathrm{M} \Omega$. In advancing the electrode slowly through ligamentum spirale and stria vascularis, often a variable positive potential was observed immediately before the high positive potential of the endolymphatic space appeared upon further penetration. Only when the electrode was advanced through the region of the prominentia spiralis a negative potential of about $50 \mathrm{mV}$ was frequently recorded before the positive ERP was measured in the endolymphatic space. This negative potential represents most likely the depolarisation of the cells of the sulcus externus, which penetrate deeply into this region. This finding has previously been reported by Butler et al. (1962).

The values for the ERP in the various cochlear turns are summarised in Table 10. There is a clear decrease in potential going from basal to

\section{Table 10}

ENDOLYMPHATIC POTENTIAL (ERP) IN THE VARIOUS COCHLEAR TURNS OF THE GUINEA PIG

\begin{tabular}{cc} 
Turn & ERP \\
No. & $(\mathrm{mV})$ \\
\hline 1 & $75+2$ \\
2 & $70 \pm 2$ \\
3 & $55 \pm 3$ \\
4 & $49 \pm 3$ \\
\hline
\end{tabular}

Means with SE from four determinations. 
apical turn, as has also been reported by Misrahy et al. (1958 b). We have demonstrated a similar decrease for the $\mathrm{Na}^{+}-\mathrm{K}^{+}-\mathrm{ATP}$ ase activity (Tables 8 and 9). Meyer zum Gottesberge et al. (1965) and Mizukoshı and Daly (1967) observed a similar distribution for the $\mathrm{O}_{2}$ consumption and Kurschner (1968) for the distribution of lactic and malic dehydrogenase activity.

Fig. 28 shows the effect on the ERP of perfusing the scala vestibuli for 50 minutes with normal Ringer's solution and Ringer to which ouabain was added $\left(10^{-3}-10^{8} \mathrm{M}\right)$. No change was found upon perfusion with normal Ringer's solution. Ouabain caused a decrease of the

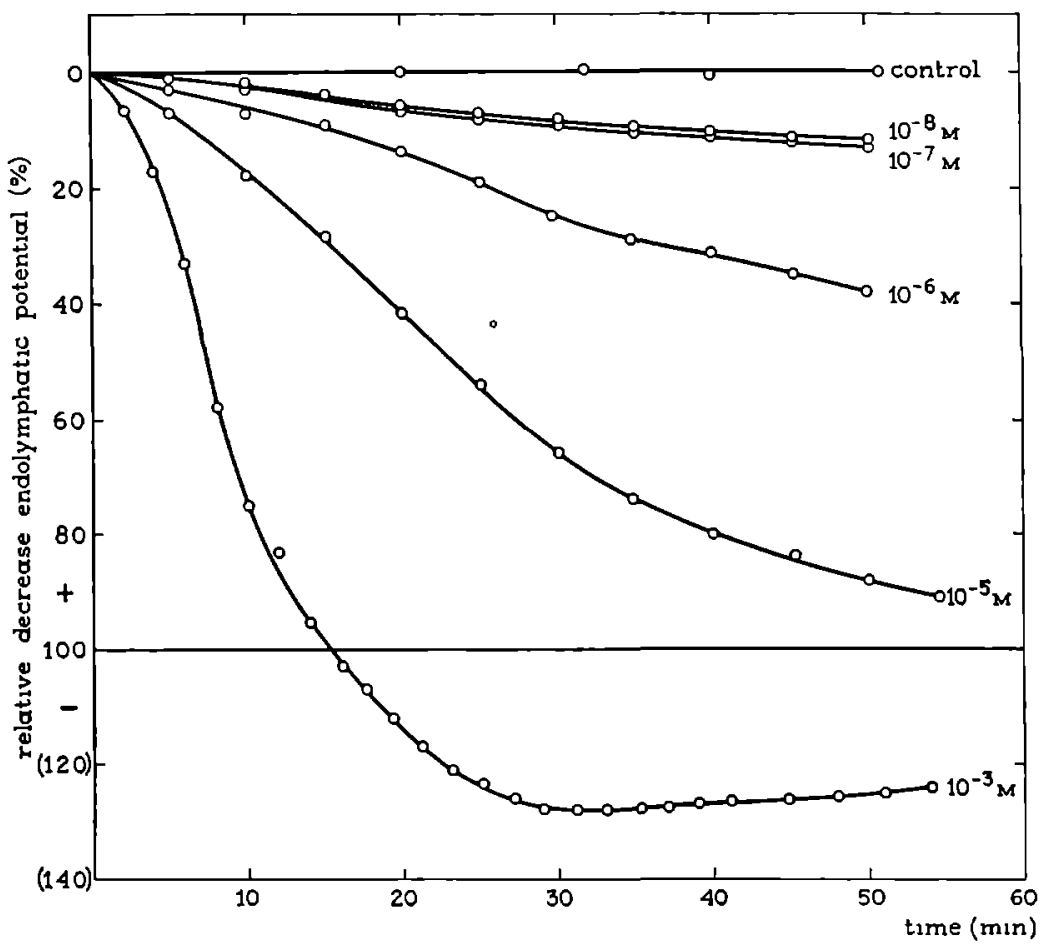

Fig 28 Effect on ERP of continuous perfusion of the scala vestibuli for 50 minutes with Ringer s solution containing various amounts of ouabain $\left(10^{8}-10^{-1} \mathrm{M}\right)$ The point at wich ERP was zero was set at $100 \%$ inhibition Inhibition larger than $100 \%$ indicates reversal of the potential Each curve represents the mean value of four experiments

ERP, which was dependent on its concentration. A remarkable effect was found with $103 \mathrm{M}$ ouabain. The potential not only decreased to zero but became even negative, reaching a maximally negative value of about $-25 \mathrm{mV}$ after 30 minutes. Upon continued perfusion this negative 
potential tended to increase slowly to zero A similar behaviour of the ERP has been demonstrated during anoxemia, which will be discussed in Chapter IX If the animal was made anoxemic, when the potential upon perfusion with $10 * \mathrm{M}$ ouabain was decreased to a stable negative value, no further decrease could be observed Therefore it may be concluded that the ERP had completely disappeared

Fig 29 shows the time course for the decrease of the ERP expressed in percentage of the original ERP value, upon perfusion of the scala vestıbulı with $10^{3} \mathrm{M}$ ouabain in Ringer's solution The corresponding

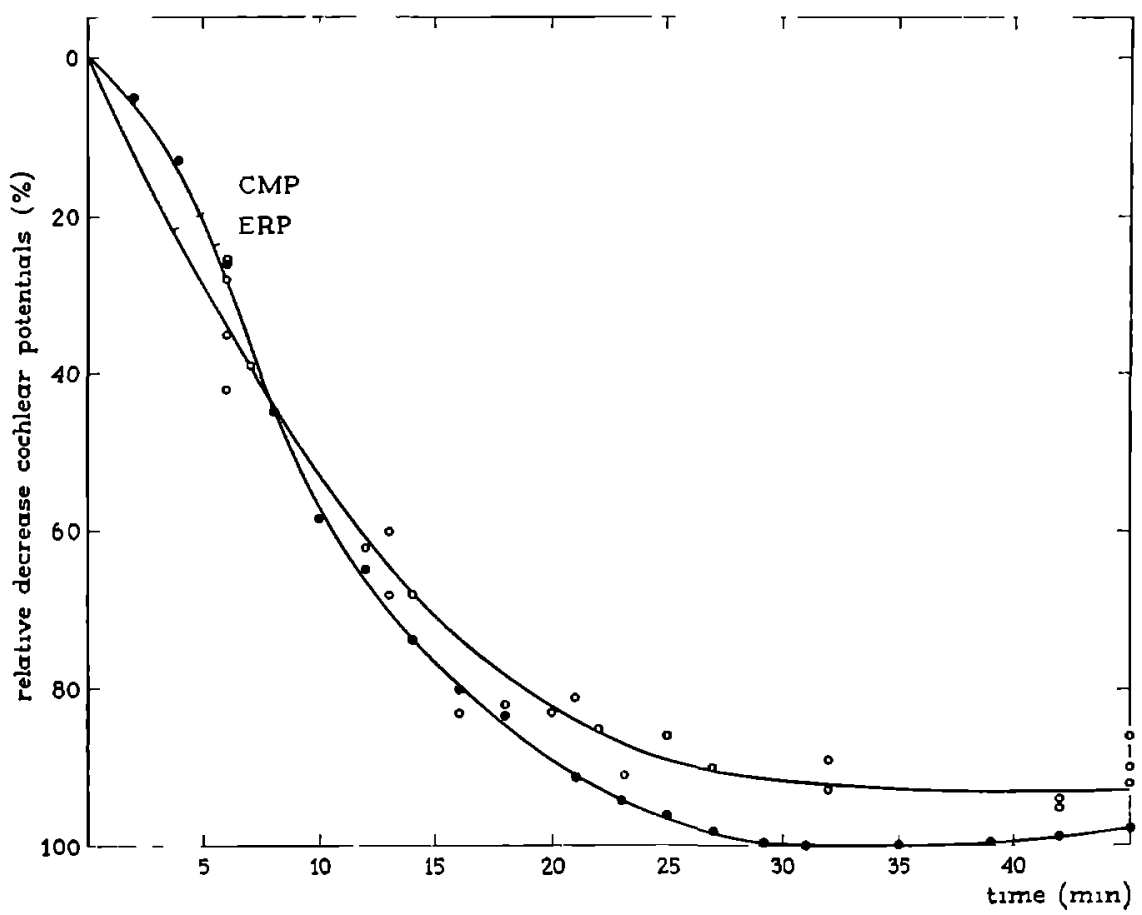

Fig 29 Time course of relative decrease of ERP upon continuous perfusion of the scala vestibulı with $10^{-s} \mathrm{M}$ ouabain in Ringer $\mathrm{s}$ solution - The point at which the ERP was maximally negative $\left(F_{1 g} 28\right)$ was set at $100 \%$ inhibition The corresponding curve for the CMP is also presented o - 0

curve for the CMP is presented for purposes of comparison The maximally negative value of the ERP after ouabain administration was taken as $100 \%$ inhibition. There is a striking resemblance in the time courses for both potentials, except that the CMP was only inhibited to $90 \%$ maximally.

Fig 30 shows the inhibitory effect of various concentrations of 


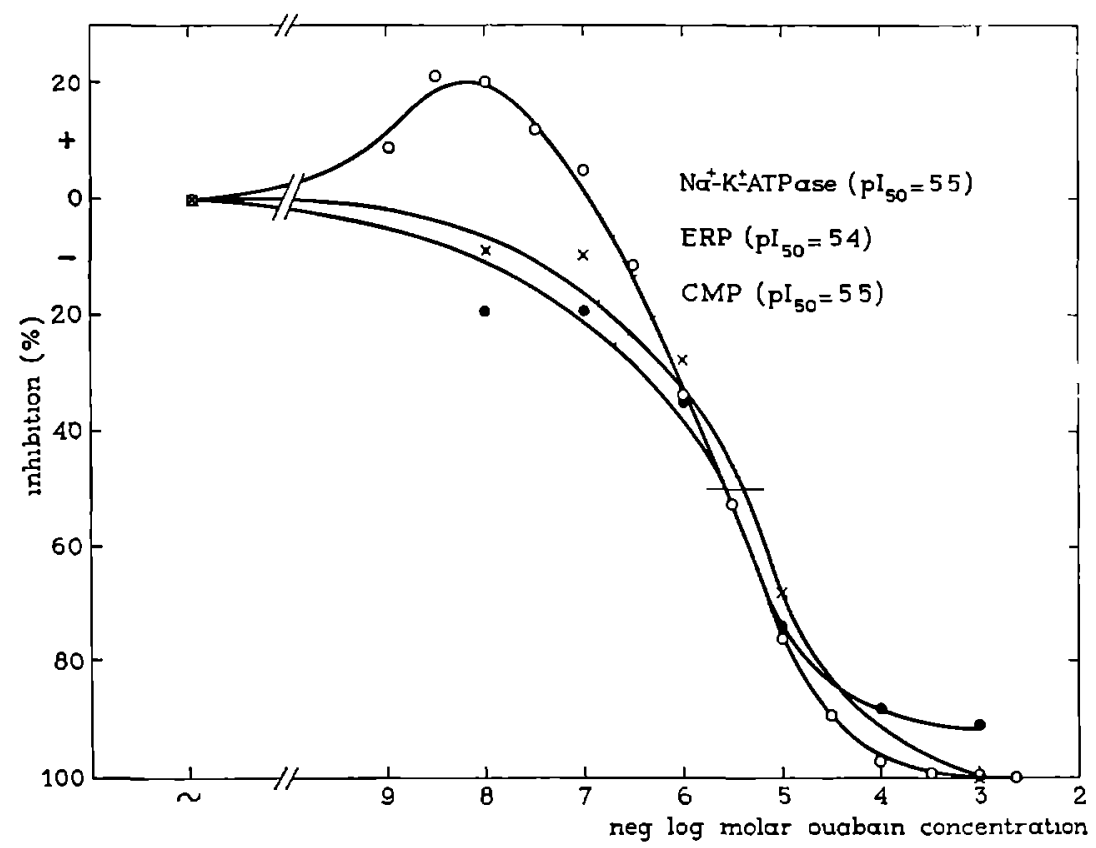

Fig 30 Effect on ERP of continuous perfusion of the scala vestibuli with Ringer $s$ solution containing various amounts of ouabain $\left(10^{-H}-10^{-3} \mathrm{M}\right)$ for 45 minutes $x-x$ The inhibitory effects of ouabain on the CMP —- and on the $\mathrm{Na}^{+} \mathrm{K}^{+}$-ATPase activity in homogenates of the stria vascularis $\mathrm{O}-\mathrm{o}$ are presented for purposes of comparison

ouabain $\left(10^{8}-10^{3} \mathrm{M}\right)$ on the ERP upon perfusing the scala vestibulı for 45 minutes The curves for the inhibition of the CMP and the $\mathrm{Na}^{+}-\mathrm{K}^{+}-\mathrm{ATP}$ ase activity in the stria vascularis homogenates are also presented in this figure. There is a strikıng similarity between these curves which have a nearly identical $\mathrm{pI}_{50}$ of 55 and 54 The stimulatory effect on the $\mathrm{Na}^{-}-\mathrm{K}^{+}$-ATPase activity at low concentrations of ouabain $(109 \mathrm{M})$ was not observed for the cochlear potentials

4. Discussion and conclusions

In view of the high $\mathrm{Na}^{+}-\mathrm{K}^{+}-\mathrm{ATPase}$ activity in the cochlear structures (Chapter VI and VII) and the effect of ouabain on both the ERP and the CMP (Figs 25 to 30 ), it may be concluded that the cochlear potentials depend on the functioning of the $\mathrm{Na}^{+}-\mathrm{K}^{+}-\mathrm{ATP}$ ase system Since this enzyme system is very predominantly located in the stria vascularis (Chapter VII), it seems very likely that this structure is responsible for the cochlear potentials

Ouabaın, perfused through the scala vestibuli, may easily reach the 
stria vascularis by free diffusion through the extracellular spaces of the spiral ligament (llberg, 1968 b) or else it may enter the vessels running through the spiral ligament towards the stria vascularis. There it will block the $\mathrm{Na}^{+}-\mathrm{K}^{+}$-ATPase cation pump system, which is located in the membrane of the marginal cells of the stria vascularis (Fig. 4) and which is responsible for maintaining the high $\mathrm{K}^{+}$and the low $\mathrm{Na}^{+}$ concentration in the endolymph, necessary for cochlear function.

The striking similarity in the effects of ouabain on the $\mathrm{Na}^{+}-\mathrm{K}^{+}$ATPase system of the stria vascularis and on the cochlear potentials with a $\mathrm{pI}_{50}$ of 55 for the inhibition of the $\mathrm{Na}^{+}-\mathrm{K}^{+}-\mathrm{ATP}$ ase system and the CMP and $\mathrm{p}_{50}$ of 54 for the ERP constitutes strong evidence for a direct relationship between the activity of the $\mathrm{Na}^{+}-\mathrm{K}^{+}-\mathrm{ATPase}$ system and the occurrence of the cochlear potentials. The only discrepancy is the presence of a stimulatory effect of low concentrations of ouabain on the $\mathrm{Na}^{+}-\mathrm{K}^{+}-\mathrm{A}$ TPase activity, which could not be demonstrated for the potentials. The fact that these low ouabain concentrations were slightly inhibitory, rather than stimulating, to the CMP and the ERP ( $\mathrm{Fig} \mathrm{30)} \mathrm{may} \mathrm{be} \mathrm{due} \mathrm{to} \mathrm{an} \mathrm{adsorption} \mathrm{of} \mathrm{ouabain} \mathrm{to} \mathrm{the}$ membranes of the cells of the stria vascularis during the 45 -minute perfusion of the scala vestibuli. Such an adsorption has also been shown by Bonting and Becker (1964) for the cells of of the ciliary epithelium, responsible for aqueous humor secretion.

An additional argument for a primary role of the $\mathrm{Na}^{+}-\mathrm{K}^{+}-\mathrm{ATP}$ ase system in the origin of at least the ERP may be derived from the decrease of the magnitude of the ERP from the basal to the apical turn (Table 10), since a similar gradient was found for the $\mathrm{Na}^{+}-\mathrm{K}^{+}-\mathrm{ATP}$ ase activity (Tables 8 and 9).

There is a remarkable similarity between the effects of ouabain. anoxemia (Konıshı et al., 1961) and of cyanıde (Konıshı and Kelsey. $1968 \mathrm{c}$ ) on the cochlear potentials. This warrants the conclusion that the energy supply for the activity of the cation pump is supplied by the oxidative metabolism. This conclusion is supported by the findings of Matchınsky and Thalmann (1967), who demonstrated a very substantial decrease in the ATP content of the stria vascularis within one minute after anoxemia The ERP has been shown to decrease at about the same rate, as will be discussed in Chapter IX.

On the basis of this evidence it seems reasonable to conclude that the ERP depends on the activity of the $\mathrm{Na}^{+}-\mathrm{K}^{+}-\mathrm{ATP}$ ase system in the stria vascularis. However this does not yet allow us to decide whether this potential arises directly from the activity of the cation pump, or secondarily from the ionic gradients maintained by the pump between endolymph and perilymph or plasma. This problem will be discussed in Chapter IX.

The similarity of the effects of ouabain on the CMP and the ERP 
indicates a close relationship between the two potentials. Such a relationship is also indicated by the effects of anoxemia and of inhibitors of the oxidative metabolism However the CMP, in contrast to the ERP, has also been shown to be dependent on the negative potential of the hair cells. Butler (1965) has demonstrated that the decrease of the CMP during anoxemia is similar to the decrease in the potential gradient across the lamina reticularis ( $\left.F_{1 g}, 6\right)$, which is the sum of the ERP and the negative potential of the hair cells. This would be in agreement with the theory of Davis (1961). who proposes that the CMP originates from a change in the resistance of the lamina reticularis due to the bending of the cilia of the hair cells, which would regulate the amount and the direction of the current through this layer This current is thought to be driven by both the ERP and the hair cell potential. The effects of ouabain perfusion on the ERP and the CMP, which we have observed, could be interpreted to support this hypothesis Although we did not measure the potential of the harr cells, we cannot exclude the possibility that ouabain perfused through the scala vestibuli might through the ligamentum spirale reach the scala tympani and thence the organ of Corti. Ouabain could then inhibit the cation pump located in these cells and thus slowly decrease the potential of the hair cells, thus contributing to the decrease in the CMP. Although conclusive evidence for this theory has never been supplied, the persistence of about $10 \%$ of the CMP after continued anoxemia and also after ouabain perfusion might be the result of the presence of a potential gradient across the lamina reticularis, originating from the difference between the negative potential of the hair cells (Chapter III) and the negative potential in the scala media, arısing upon anoxemia or ouabain perfusion (Chapter IX). 
THE NATURE OF THE ENDOLYMPHATIC RESTING POTENTIAL AND COMPOSITION OF THE PERILYMPH

\section{Introduction}

In the previous chapter we showed the dependence of the endolymphatic resting potential (ERP) on the functioning of the $\mathrm{Na}^{+}-\mathrm{K}^{+}$ATPase system in the stria vascularis. This does, however, not yet explain the exact nature of this potential. To this problem we direct ourselves in this chapter. In most cells the potential difference across the cell membrane is a diffusion potential, which is due to the ronic concentration gradients between cytoplasm and extracellular fluid and which is determined by the relative permeabilities of the cell membrane for the ions. Such a potential is only indirectly dependent on the activity of the cation pump, namely in as far as the latter is responsible for maintaining the ion gradients responsible for the potential. The diffusion potential is given by the constant field equation formulated by Hodgkın and Katz (1949).

$E=-\frac{R T}{F} \ln \frac{P_{K}\left(K_{1}^{+}\right)+P_{N_{a}}\left(\mathrm{Na}_{1}^{+}\right)+P_{C l}\left(\mathrm{Cl}_{0}^{-}\right)}{P_{K}\left(K_{0}^{+}\right)+P_{N a}\left(\mathrm{Na}_{0}^{+}\right)+P_{C l}\left(\mathrm{Cl}_{1}^{-}\right)}$

In this equation $\mathrm{R}$ represents the gassconstant, $\mathrm{T}$ the absolute temperature, $\mathrm{F}$ the Faraday constant and $o$ and 1 refer to the concentrations of $\mathrm{K}^{+}, \mathrm{Na}^{+}$and $\mathrm{Cl}^{-}$outside and inside the cell respectively, $\mathrm{P}_{\mathrm{K}}, \mathrm{P}_{\mathrm{Na}}$ and $\mathrm{P} C \mathrm{Cl}$ are the permeability constants of these 1ons. The validity of this relation has been shown for many types of biological membranes as nerve, muscle and lens. In the case of resting nerve and muscle and of the electroplax of the electric eel, the potential is mainly determined by the $\mathrm{K}^{+}$gradient, because the membrane is much more permeable to $\mathrm{K}^{+}$than to $\mathrm{Na}^{+}$and $\mathrm{Cl}^{-}$. Because $\left(\mathrm{K}_{1}^{+}\right)$is much larger than $\left(\mathrm{K}_{0}^{+}\right)$, the inner side of the cell membrane is negative (about $80 \mathrm{mV}$ ) with respect to the outer side.

Since the ERP is positive with regard to plasma and perilymph, and $\left(\mathrm{K}^{+}\right)$in the endolymph is high, this suggests that it cannot be a $\mathrm{K}^{+}$ diffusion potential. This led Johnstone (1967) to assume that it could 
be a $\mathrm{Na}^{+} \mathrm{d}_{1}$ ffusion potential. Neglecting the $\mathrm{Cl}^{-}$contribution, he could then arrive at a potential of $+82 \mathrm{mV}$, if he set the permeability ratio $\mathrm{P}_{\mathrm{Na}} / \mathrm{P}_{\mathrm{K}}$ for the cochlear membranes at 50 as it is for the squid axon membrane during the rising phase of the action potential (Hodgkin and Katz, 1949, Nastuk and Hodgkın, 1950) and if he used the known cation concentrations in endolymph $\left(\mathrm{K}^{+}, 150 \mathrm{mM} ; \mathrm{Na}^{+}, 3 \mathrm{mM}\right)$ and plasma $\left(\mathrm{Na}^{+}, 140 \mathrm{mM} ; \mathrm{K}^{+}, 5 \mathrm{mM}\right)$. He further assumed that the fast decrease of the ERP in anoxemia, when no change in the $\mathrm{Na}^{+} / \mathrm{K}^{+}$ratio has yet occurred (Johnstone, 1965), would be due to a change in the permeability ratio $\mathrm{P}_{\mathrm{Na}} / \mathrm{P}_{\mathrm{K}}$ to 02 , which would result in the observed negative potential of $-30 \mathrm{mV}$. If this hypothesis should be correct the $\mathrm{Na}^{+}-\mathrm{K}^{+}-\mathrm{ATPase}$ system would only act to maintain the intracellularlike cation concentration of the endolymph, while the ERP would merely be the expression of the $\mathrm{Na}^{+}$gradient between endolymph and plasma or perilymph

In an attempt to determine whether the ERP could be an ionic diffusion potential, we have observed the effects on the ERP of perfusing the perilymphatic space with solutions having various ionic contents (Table 11) In further experiments the effect on the ERP of rupturing Reissner's membrane was studied. In addition we have looked for a

Table 11

COMPOSITION OF PERFUSION FLUIDS *

\begin{tabular}{|c|c|c|c|c|c|}
\hline & $\begin{array}{l}\mathrm{K}^{+} \\
\text {Ringer }\end{array}$ & $\begin{array}{l}\mathrm{L}^{+} \\
\text {Ringer }\end{array}$ & $\begin{array}{l}\mathrm{SO}_{4}{ }^{2-} \\
\text { Runger }\end{array}$ & $\begin{array}{l}\text { Choline } \\
\text { Ringer }\end{array}$ & $\begin{array}{l}\text { Sucrose } \\
\text { Ringer }\end{array}$ \\
\hline $\mathrm{L}_{1}{ }^{+}$ & - & 149 & - & - & - \\
\hline $\mathrm{Na}^{+}$ & - & - & 149 & - & - \\
\hline $\mathrm{K}^{+}$ & 1535 & 45 & 45 & 45 & 45 \\
\hline $\mathrm{Ca}^{2+}$ & 13 & 13 & 13 & 13 & 13 \\
\hline $\mathrm{Mg}^{2+}$ & 08 & 08 & 08 & 08 & 08 \\
\hline $\mathrm{Cl}^{-}$ & 1312 & 1532 & 26 & 1662 & 42 \\
\hline $\mathrm{HCO}_{-}^{-}$ & 25 & 3 & 3 & 3 & 3 \\
\hline $\mathrm{HPO}_{4}{ }^{2-}$ & 05 & 05 & 05 & 05 & 05 \\
\hline $\mathrm{H}_{2} \mathrm{PO}_{4}^{-}$ & 05 & 05 & 05 & 05 & 05 \\
\hline Cholıne & - & - & - & 162 & - \\
\hline $\mathrm{SO}_{4}{ }^{2-}$ & - & - & 753 & - & - \\
\hline Sucrose & - & - & 75 & - & 297 \\
\hline
\end{tabular}

* All concentrations in mmole/l pH adjusted to 74

possible $\mathrm{pH}$ dependence of the ERP, because Rauch (1964) has suggested that a slight difference in $\mathrm{pH}$ between perilymph and endo- 
lymph, as reported by Misrahy et al. (1958 c) could give an important contribution to the ERP. We have observed the ERP during perfusion of the perilymphatic space with Ringer's solutions of different $\mathrm{pH}$ and also while making the animal respire a gasmixture of $20 \% \mathrm{CO}_{2}$ and $80 \% \mathrm{O}_{2}$ so as to create a respiratory acidosis.

The nature of the negative potential occurring after anoxemia or upon applying ouabain to the perilymph was studied in a similar way. namely by changing the composition of the perfusing fluid.

The inner ear structures contain a very high activity of carboanhydrase (Erulkar and Maren, 1961) which is primarıly localised in the stria vascularıs (Eggemann and Bruchmuller, 1968) Intravenous admınistration of acetazolamide, a strong inhibitor of carboanhydrase, caused a large decrease in the $\mathrm{K}^{+}$concentration of the endolymph (Erulkar and Maren, 1961) and a disappearance of the vacuoles in the marginal cells of the stria vascularis (Johnson and Spoendlın, 1966). Since these experiments suggested a role of the carboanhydrase system in cochlear cation transport, we also studied the effect on the ERP of perfusing acetazolamide through the scala vestibuli

\section{Effect of electrolyte changes in the perilymph}

The effect on the ERP of removing $\mathrm{Na}^{+}$from the perilymph was studied by continuously perfusing the scala vestibulı with Ringer's solutions in which $\mathrm{Na}^{+}$was replaced by $\mathrm{Li}_{1}^{+}$or sucrose $W_{1}$ th sucrose Ringer, perfused at the rate of $10 \mu \mathrm{l} / \mathrm{m} ı n$, there was an increase of the ERP by about $5 \mathrm{mV}$ within one minute after the start of the perfusion. The potential remained at this level for several minutes, and then it started to decrease. At a perfusion rate of $15 \mu \mathrm{l} / \mathrm{m} / \mathrm{n}$ the increase appeared to be slightly higher, but it was nearly absent at $6 \mu \mathrm{l} / \mathrm{m} 1 \mathrm{n}$. Perfusion with normal Ringer at the same rates falled to show any change in the ERP Therefore, we ascribe the temporary increase in the ERP with the sucrose Ringer to an increase in hydrostatic pressure. caused by the high viscosity of this solution. A similar increase of the ERP after application of positive pressure to the scala vestibuli has been reported by Tasakı et al. (1954) In subsequent experiments we therefore used a perfusion rate of $6 \mu \mathrm{l} / \mathrm{min}$ for sucrose Ringer

The effects on the ERP during perfusion of the scala vestibuls with sucrose Ringer and $\mathrm{Ll}_{1}+$ Ringer is shown in $\mathrm{F}_{1 \mathrm{~g}}$ 31. Each curve represents mean values of six determinations. There is a remarkable simılarity between the effects of $\mathrm{L}_{1}{ }^{+}$and sucrose Ringer. The potential is decreased by $18 \%$ with $\mathrm{L}_{1}+$ Ringer and by $15 \%$ with sucrose Ringer after continuous perfusion for 22 minutes. The decrease of the ERP immediately ceased and could be reversed to a variable degree upon perfusing with normal Ringer. The recovery process varied to a certain extent in different experiments Sometimes the potential increased to 


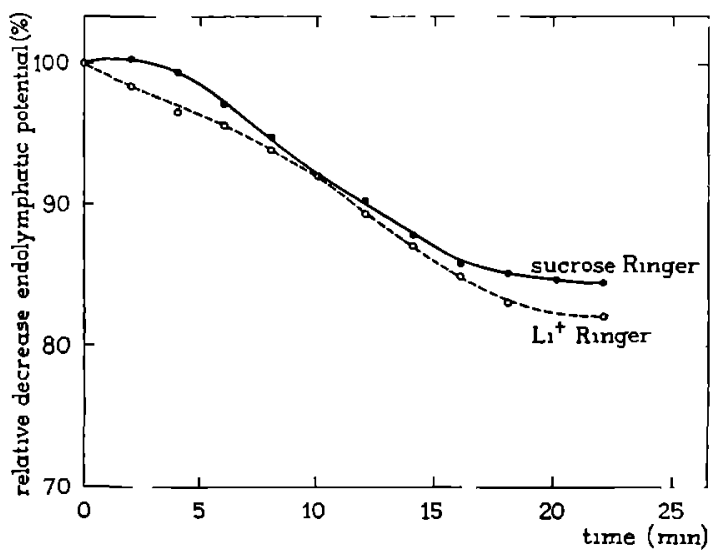

Fig 31 Effect on ERP of continuous perfusion of the scala vestibulı with sucrose Ringer - - and $\mathrm{L}_{1}+\mathrm{R}$ inger $\mathrm{O}-\mathrm{O}$ Each curve represents the mean value of six experiments

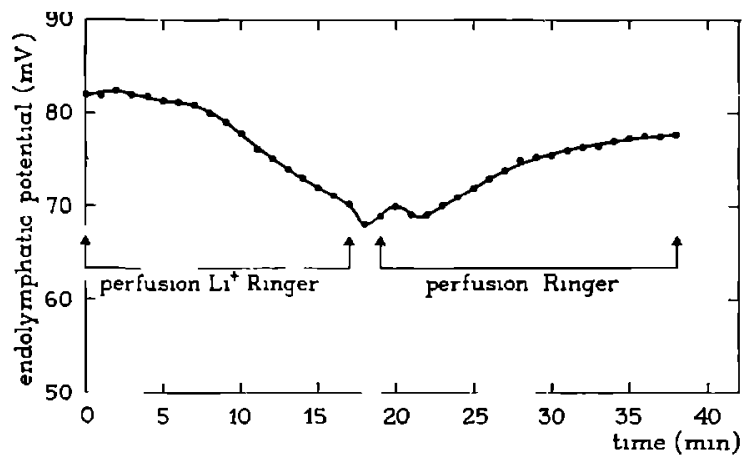

Fig 32 Fffect on ERP of continuous perfusion of the scala vestibul with $\mathrm{L}_{1}+$ Ringer and subsequent perfusion of normal Ringer s solution.

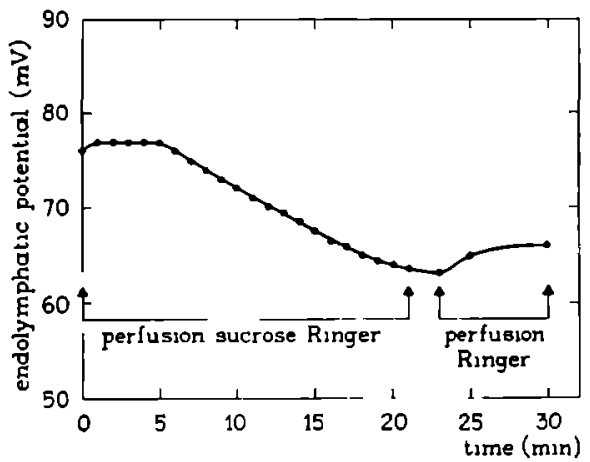

$F_{1 g} 33$ Effect on ERP of continuous perfusion of the scala vestibuli with sucrose Ringer and subsequent perfusion of normal Ringer s solution 
nearly its original value (Fig. 32), but often only a slow and partial recovery was obtained (Frgs. 33 and 34). The latter phenomenon was more frequently observed after longterm perfusion, suggesting that it might be due to damage of the cochlear membranes. However, this seems unlıkely, because perfusion with normal Ringer for 45 minutes failed to show any effect on the ERP or CMP (Figs. 27 and 28). A more likely explanation is that perfusion with sucrose or $\mathrm{Li}^{-}$would affect cell metabolism or membrane permeability somewhat. Additional evidence that the absence of $\mathrm{Na}^{-}$in the perfusate is responsible for the decrease of the ERP is presented in Fig. 34. The decrease of the ERP, initiated by perfusion with sucrose Ringer, continued during

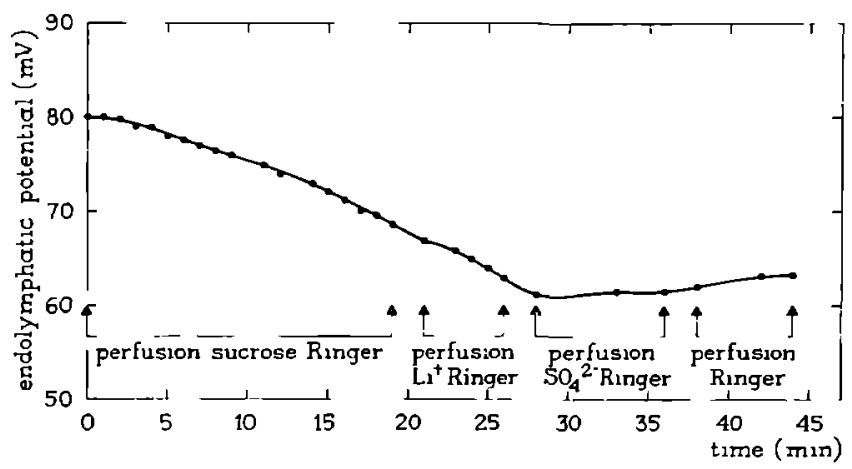

Fig. 34. Effect on ERP of continuous perfusion of the scala vestibul 1 with sucrose Ringer, followed by perfusion with $\mathrm{Li}^{+} \mathrm{R}$ inger, $\mathrm{SO}^{2}{ }^{2-R i n g e r}$ and normal Ringer's solution.

subsequent perfusion with $\mathrm{Li}^{+}$Ringer, but it ceased when $\mathrm{Na}_{2} \mathrm{SO}_{4}$ Ringer was perfused and a slight recovery was obtained with normal Ringer.

In contrast to the slight effect of perfusing $\mathrm{Na}^{+}$free Ringer a dramatic effect on the ERP was obtained by perfusing the scala vestibuli with Ringer in which $\mathrm{Na}^{+}$was replaced by $150 \mathrm{mM} \mathrm{K} \mathrm{K}^{+}$. The results of three experiments are shown in Fig. 35. Within one minute after starting perfusion the potential rose sharply sometimes more than $20 \mathrm{mV}$ and thereafter a fast decrease was observed to about $50 \%$ of the original value. When perfusion was stopped, the potential recovered slowly and only partially. This recovery, which is presumably due to exchange of the excess $\mathrm{K}^{+}$by $\mathrm{Na}^{+}$from the continuous flow of perilymph. could not be enhanced by perfusion with normal Ringer.

The contribution of $\mathrm{Cl}^{-}$to the ERP was investigated by perfusing the scala vestibuli with $\mathrm{Ringer}$ solution in which $\mathrm{Cl}^{-}$was replaced by $\mathrm{SO}_{4}{ }^{2-}$ to which most membranes are much less permeable than to $\mathrm{Cl}^{-}$. 


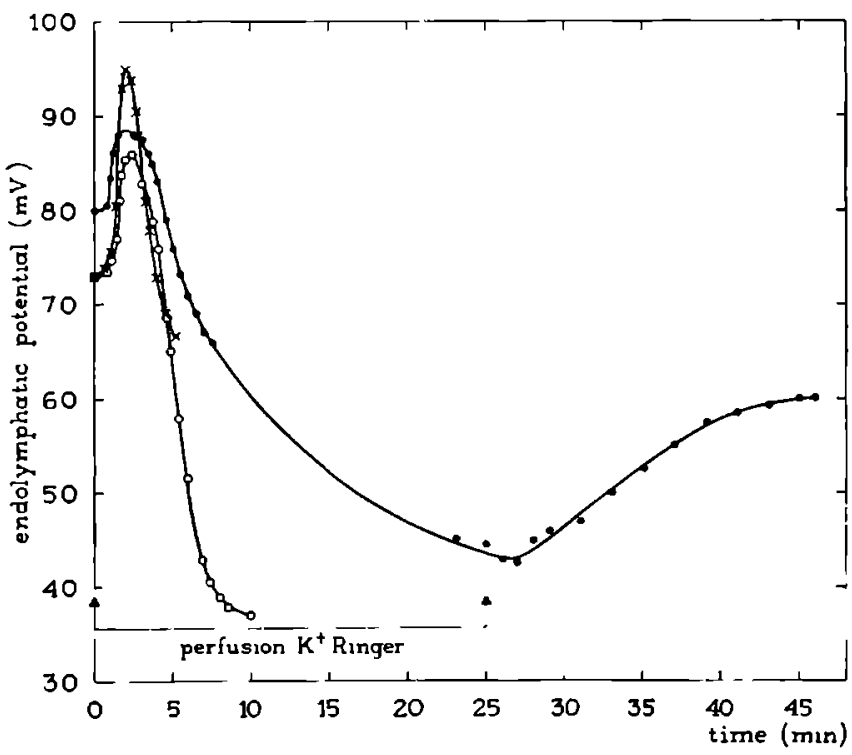

Fig. 35. Effect on ERP during and after continuous perfusion of the scala vestibuli with $\mathrm{K}^{+}$Ringer in three experiments.

The results, shown in Fig. 36, indicate that omission of $\mathrm{Cl}^{-}$affected the potential to a very slight extent only, and the effect could be restored with normal Ringer. This is in agreement with the fact that sucrose Ringer, which has a very low $\mathrm{Cl}^{-}$concentration, had the same effect on the ERP as $\mathrm{Li}^{+}$Ringer, which has a normal $\mathrm{Cl}^{-}$content. The nearly equal $\mathrm{Cl}^{-}$contents of endolymph and perilymph also indicate that $\mathrm{Cl}^{-}$ could not contribute significantly to the ERP (Table 1).

In an attempt to investigate the role of Reissner's membrane in the occurrence of the ERP, we ruptured this membrane. After careful removal of the bony wall of the scala vestibuli of the exposed part of the

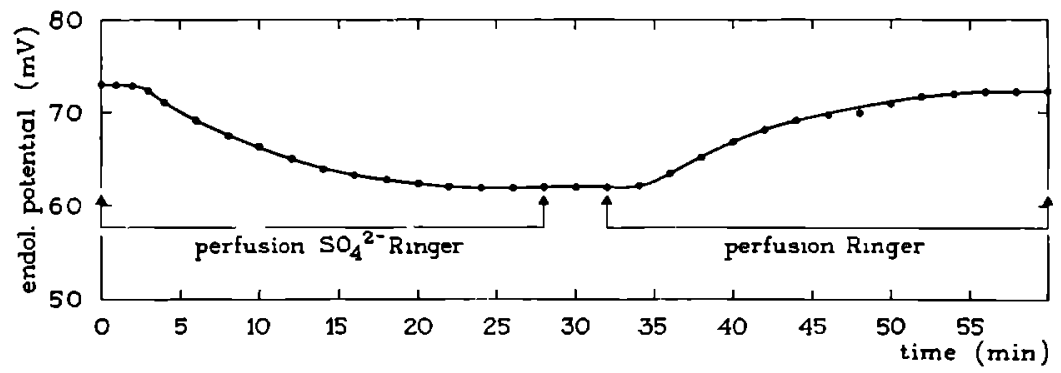

Fig. 36. Effect on ERP of continuous perfusion of the scala vestibul 1 with $\mathrm{SO}^{2-}$ Ringer and subsequent perfusion with normal Ringer. 
basal turn, Reissner's membrane was ruptured thoroughly with a fine glass needle. The potential decreased rapidly to about $+15 \mathrm{mV}$ and thereafter dimınished slowly, becoming zero within about 15 minutes. However when immediately after rupturing Reissner's membrane the cochlear fluid was removed by suction, the potential increased by about $10 \mathrm{mV}$ and then slowly decreased to about $+15 \mathrm{mV}$ upon ceasing suction The decrease to $+15 \mathrm{mV}$ concided with the rise of the flund level in the cochlear space caused by perilymph production. This effect could be repeatedly found even when the potential was nearly zero. about fifteen minutes after the destruction of Reissner's membrane.

\section{Effect of pH on the potential}

The dependence of the ERP on a difference in $\mathrm{pH}$ between endolymph and perilymph was investigated by perfusing the scala vestibuli with Ringer's solutions in which the $\mathrm{pH}$ was brought to 6.0 and 80 by addition of lactic acid and of $\mathrm{NaOH}$, respectively. Continuous perfusion with these solutions for 25 minutes falled to show any effect on the potential.

In a second group of experiments a general respiratory acidosis was established by making the animal respire a gas mixture consisting of $80 \% \mathrm{O}_{2}$ and $20 \% \mathrm{CO}_{2}$. The $\mathrm{pH}$ of the blood was decreased from 7.3 to 6.8 while the $\mathrm{pCO}_{2}$ appeared to be more than $180 \mathrm{~mm}$. Under these conditions Misrahy et al. (1958 b) measured a decrease in endolymph $\mathrm{pH}$ of the same magnitude. The ERP decreased to about $93 \%$ of its original value within ten minutes, and could not be returned to normal

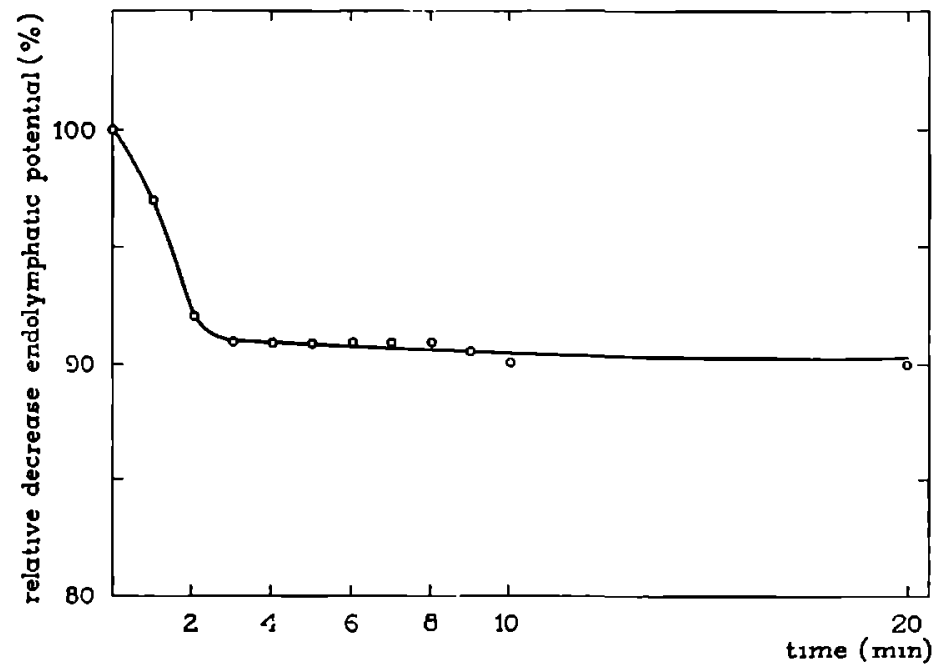

Fig 37 Effect on ERP of ccntinuous perfusion of the scala vestibulı with $10^{-s} \mathrm{M}$ acetazolamide in Ringer $s$ solution (Mean value of four experiments) 
by perfusing the scala vestibuli with normal Ringer of $\mathrm{pH} 74$. When subsequently the animal was made to respire a gas mixture consisting of $95 \% \mathrm{O}_{2}$ and $5 \% \mathrm{CO}_{2}$, the potential returned within a few minutes to its original value.

The effect of acetazolamide, an inhibitor of carboanhydrase was studied by perfusing the scala vestibulı with Ringer's solution containing 10-3 $\mathrm{M}$ acetazolamide. The results of four experiments are shown in Fig. 37. The potential decreased rapidly to 91 (SE: 1.3$) \%$ of 1 ts original value within three minutes after starting perfusion. During the subsequent 17 minutes only a very slight decrease to $90^{\prime} c$ was observed. The resemblance between the effects of $\mathrm{CO}_{2}$ inhalation and of acetazolamide perfusion may be due to an increase of intracellular $\mathrm{CO}_{2}$ resulting in cellular acidosis in both cases (Slegers and Moons, 1968). The resulting decrease in intracellular $\mathrm{pH}$ could inhibit the cation pump, since the $\mathrm{Na}^{+}-\mathrm{K}^{+}$-ATPase system in the stria vascularis has a $\mathrm{pH}$ optimum of 7.3 and its activity falls considerably at lower $\mathrm{pH}$ (Fig. 21).

\section{Experimental effects on the nature of the negative potential}

The effect on the ERP and the venous $\mathrm{O}_{2}$ pressure of anoxemia, induced by making the anımal respire $20 \% \mathrm{CO}_{2}-80 \%, \mathrm{~N}_{2}$, is demonstrated in Figs 38 and 39. The ERP decreased within four minutes to $-12 \mathrm{mV}$, and thereafter slowly returned to zero in about two and a half hours. In our experiments the value of the negative potential varied between 10 and $35 \mathrm{mV}$. Assuming tentatively that the negative potential represents a $\mathrm{K}^{+}$diffusion potential, we perfused the scala vestibulı of the anoxemic animal with $\mathrm{K}^{+}$free Ringer Surprisingly this led to reversal of the potential. This has previously been reported by Honrubia et al. (1965), who suggested that it was due to removal of accumulated products of anaerobic metabolism However, when we added $20 \mathrm{mM}$ lactic acid to the perfusing fluid, the effect still occurred ( $\left.F_{1 g} .40\right)$, while upon stopping perfusion the potential returned again to its original negative value This suggests that the potential reversal upon perfusion of the scala vestibuli is due to oxygen present in the perfusing flud To test this hypothesis $10 \mathrm{mM} \mathrm{NaCN}$ was added to the perfusing fluid. In this case the potential remained negative except for a slight transient increase $\left(F_{1 g} .41\right)$, which proves that the effect is indeed due to oxygen present in the perfusing fluid. In further experiments the negative potential was, therefore, obtained by addition of $10^{-3} \mathrm{M}$ ouabain to the perfusing fluid. This has the added advantage that the general metabolism of the anımal remains unaffected, because the very small amount of ouabain administered to the perfusate leaves almost entirely with the outflowing mixture of perilymph and perfusate.

The scala vestibulı was perfused with Ringer's solution containing 


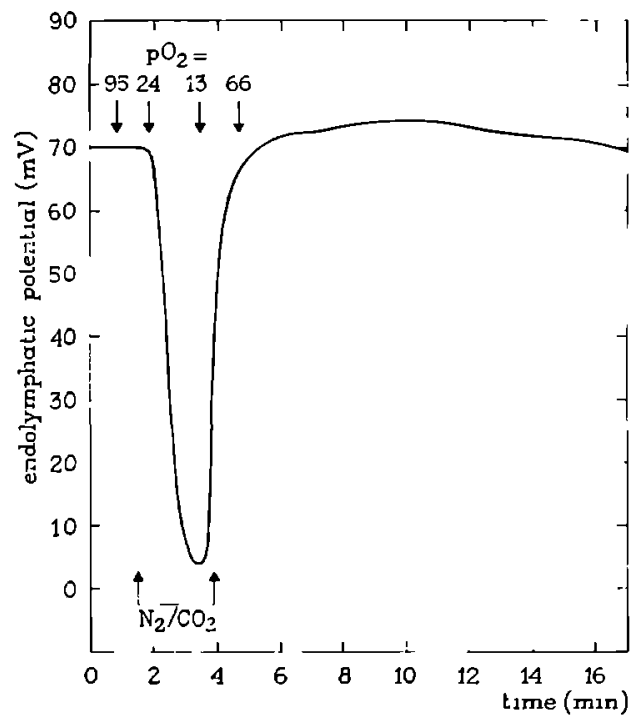

Fıg. 38. The ERP and venous $\mathrm{pO}_{2}$ before, during and after temporary anoxemı from inhalation of a gas mixture consisting of $20 \% \mathrm{CO} 2$ and $80 \% \mathrm{~N}_{2}$.

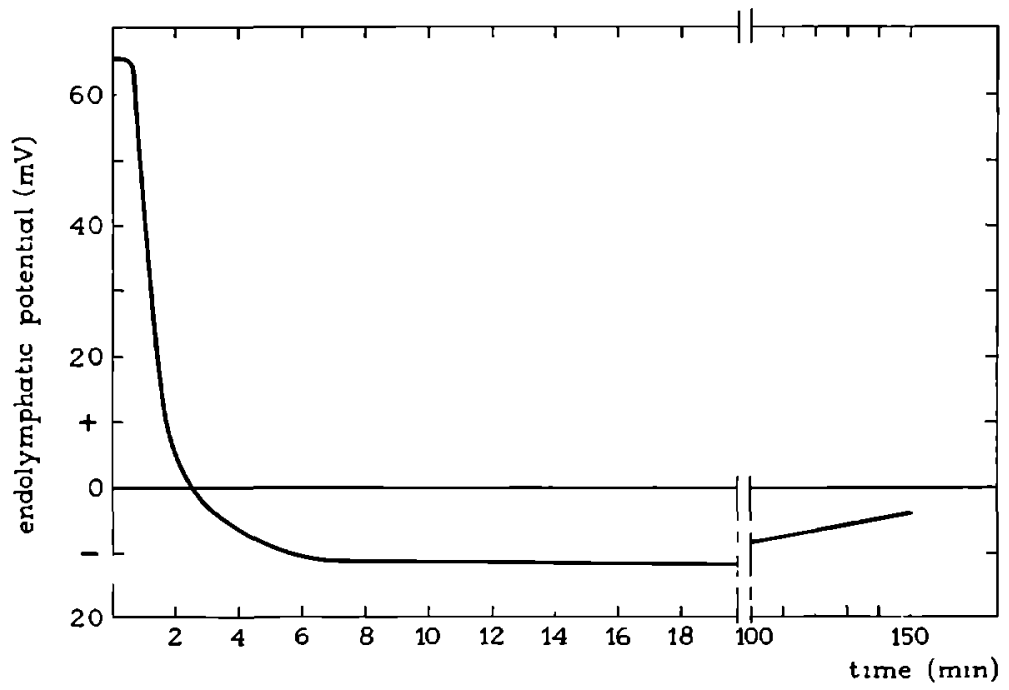

Fig. 39. Effect on ERP of prolonged anoxemia from inhalation of a gasmixture consisting of $20 \%$ CO. and $80 \%$ N.2.

10-3 $\mathrm{M}$ ouabain until the potential had reached a stable negative value, usually, in about 30 minutes. Thereafter the scala vestibuli was perfused with solutions of various ionic compositions, but always con- 


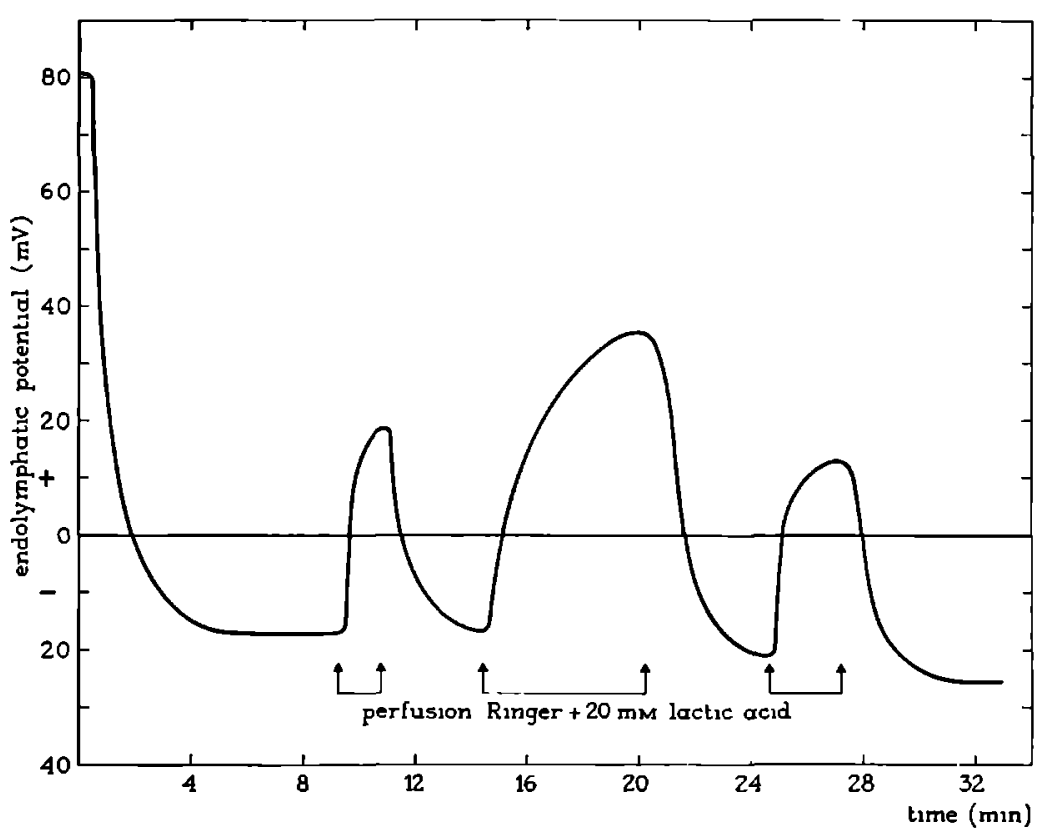

Fig 40 Effect on ERP of prolonged anoxemia and of perfusion of the scala vestibulı of the anoxemic animal with $20 \mathrm{mM}$ lactic acid in Ringers solution Anoxemia was induced at $\mathrm{t}=0$

taining 10-3 $\mathrm{M}$ ouabain. When Ringer's solution, in which $\mathrm{Na}^{+}$was replaced by choline was perfused, no effect on the negative potential was found ( $F_{1 g}$. 42). The slight increase before choline Ringer perfusion was started may have been due to a movement of the electrode. When perfusion of $\mathrm{K}^{+}$Ringer ( $\mathrm{K}^{-}$replacing $\mathrm{Na}^{+}$) was started, the potential rose immediately to nearly zero within five minutes. A small fraction of the negative potential about $3 \mathrm{mV}$, was repeatedly found to persist Subsequent perfusion with normal or choline Ringer's solution made the potential gradually decrease to negative values due to the removal of $\mathrm{K}^{+}$. If $\mathrm{K}^{+}$Ringer was again perfused, the potential immediately increased to nearly zero.

\section{Discussion and conclusions}

The large effect on the ERP of raising the $\mathrm{K}^{+}$concentration in the scala vestibul $l_{1}$ and the small effect on this potential of lowering the $\mathrm{Na}^{+}$ concentration in this compartment (Figs. 31 to 35 ) show clearly that the cochlear membranes are much more permeable for $\mathrm{K}^{+}$than for $\mathrm{Na}^{+}$. It is unlikely that the $\mathrm{K}^{+}$effect could be due to stimulation of the $\mathrm{Na}^{+}-\mathrm{K}^{+}-\mathrm{AT}$ Pase system in the stria vascularis, because the enzyme is 


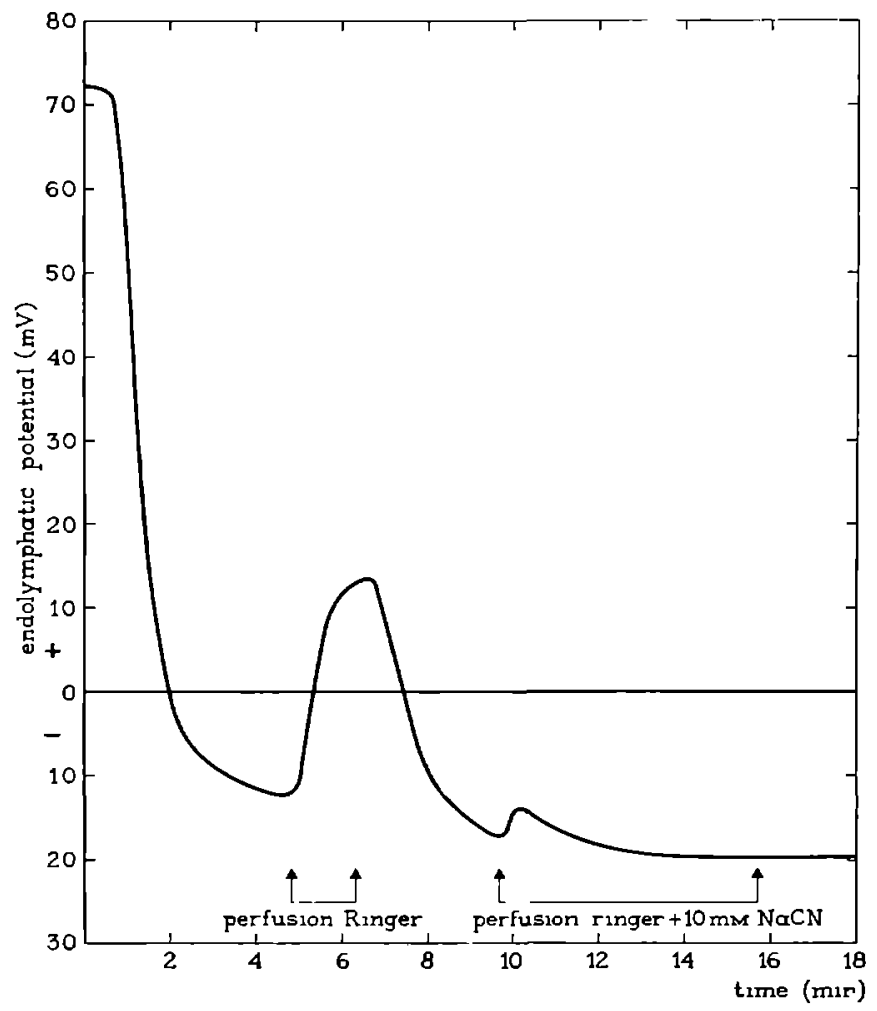

Fig. 41 Effect on ERP of prolonged anoxemia and of perfusion of the scala vestibuli of the anoxemic animal with $10 \mathrm{mM} \mathrm{NaCN}$ in Ringer's solution. Anoxemia was induced at $\mathrm{t}=\mathrm{o}$.

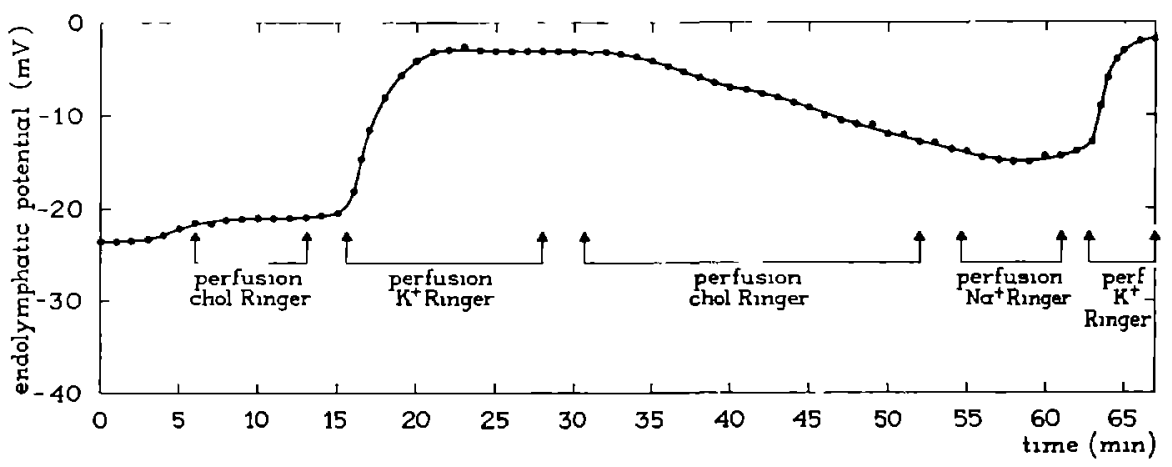

Fig 42. Effect on the negative endocochlear potential during perfusion of the scala vestibuli with solutions of various tonic composition. The negative potentral was obtained by perfusing the scala vestibuli for 30 minutes with $10^{-3} \mathrm{M}$ ouabain in Ringer's solution. 
nearly maximally activated at $5 \mathrm{mM} \mathrm{K}^{+}$, which is the normal $\mathrm{K}^{+}$concentration in blood plasma. Therefore the $20 \mathrm{mV}$ increase in the ERP must represent the disappearance of the $\mathrm{K}^{+}$diffusion potential, resulting from the unequal distribution of $\mathrm{K}^{+}$in perilymph and endolymph. This conclusion is confirmed by the disappearance of the negative potential caused by ouabain, upon perfusing the scala vestibuli with high-K+ Ringer and the lack of an effect on the negative potential of perfusion with a $\mathrm{Na}^{+}$free Ringer.

The permeability characteristics of the tympanal wall of the scala media cannot be very different from those of the other cochlear membranes in view of the fact that Butler (1965) found an occasional increase of the ERP during perfusion of the scala tympanı with $150 \mathrm{mM}$ $\mathrm{K}^{+}$. No significant effect on the ERP could be found by perfusing the scala tympanı with $\mathrm{Na}^{+}$-free solutions (Konıshı and Kelsey, 1968 a) An additional argument against a high $\mathrm{P}_{\mathrm{N}_{\mathrm{c}}} / \mathrm{P}_{\mathrm{K}}$ ratio for the cochlear membrane is the fallure to affect the ERP with tetrodotoxin, which blocks $\mathrm{Na}^{+}$inflow during the rising phase of the nerve action potential (Katsukı et al , 1966, Konishı and Kelsey, 1968 b). The suggestion of Johnstone (1967) that the negative potential in anoxemia would be due to a change in the permeability ratio by the absence of oxygen is made unlikely by the occurrence of this negative potential after ouabain administration These findings constitute convincing evidence against Johnstone's suggestion that the ERP would be a $\mathrm{Na}^{+}$diffusion potential. Johnstone (personal communication) has meanwhile obtained experimental evidence, which also argues against this suggestion.

The subsequent decrease of the ERP, which was observed by us after perfusing the scala vestbulı with high $\mathrm{K}^{+}$Ringer and also by Butler (1965) after perfusing the scala tympani with $150 \mathrm{mM} \mathrm{KCl}$. might be due to an adverse effect of high extracellular $\mathrm{K}^{+}$concentration on cell metabolism (Schoffeniels, 1967). Significant increase in cell volume at high external $\mathrm{K}^{+}$concentration has been reported by Ussing et al. (1965). The incomplete recovery of the ERP upon perfusion with normal Ringer would also be in accordance with this explanation

A significant contribution of $\mathrm{Cl}^{-}$ions to the ERP can also be excluded on the basis of the experiment presented in Fig. 36 Likewise a contribution of $\mathrm{H}^{+}$ions is ruled out by the absence of a $\mathrm{pH}$ effect on the ERP

The experiments with a high $\mathrm{K}^{+}$solution in the scala vestibuli, both on the ERP and on the negative potential due to ouabain, clearly show that the $\mathrm{K}^{+}$gradient between endolymph and perilymph does contribute to the ERP. This is, however, a negative contribution of about $20 \mathrm{mV}$. We must then conclude that the normal ERP of about +80 $\mathrm{mV}$ is the sum of two potentials, a positive potentid of about $+100 \mathrm{mV}$ 
(designated $E_{+100}$ ) and a negative potential of about $-20 \mathrm{mV}$ (designated $E_{-20}$ ). The $E_{-20}$ is mainly a $\mathrm{K}^{+}$diffusion potential

We still have to explain the $\mathrm{E}_{\perp 100}$. We have shown that it cannot be an ion diffusion potential. This leaves the possibility that it is a secretion potential, generated by an electrogenic cation pump, which pumps a single ion without coupled transport of a counter ion. The cation pump must be the $\mathrm{Na}^{+}-\mathrm{K}^{+}$-ATPase system of the stria vascularis on the basis of our results reported in Chapter VIII. However, it cannot act as an electrogenic $\mathrm{Na}^{+}$pump in this case, since the endolymphatic resting potential is positive rather than negative.

There are two strong arguments in favour of an electrogenic pump being responsible for $E_{\dashv 100}$. First, there is the persistence of the ERP, though at a much lower value, after rupturing Reissner's membrane. All cation gradients across the stria vascularis and between scala media and scala vestibulı and tympanı have been abolished in this case, and yet a potential remains. Secondly, in anoxemia the ERP disappears very rapidly, before the $\mathrm{K}^{+} / \mathrm{Na}^{\top}$ ratio undergoes a significant change (Johnstone, 1965).

The occurrence of a positive secretion potential in connection with an electrogenic cation pump has been observed in the frog skın (Koefoed-Johnsen, 1957), the culiary body of the eye (Cole, 1961), the nasal gland of marine birds (Thesleff and Schmidt-Nielsen, 1962), the choriord plexus (Patlak, 1964) and the toad bladder (Herrera, 1968) With $E_{+100}$ they have in common that they are highly sensitive to ouabain and that they are all due to the action of the $\mathrm{Na}^{+}-\mathrm{K}^{+}$ATPase system (Bonting and Becker, 1964; Bonting et al., 1964 a; Vates et al. 1964; Bonting and Canady, 1964). However there are two differences between these potentials and the $E_{+100}$. These potentials are small, ranging from $3-20 \mathrm{mV}$, and the positive potential is in the compartment to which $\mathrm{Na}^{+}$is being pumped. In the cochlea the potential is much larger and it is positive in the compartment from which $\mathrm{Na}^{+}$ is extruded. Thus the $E_{\mid} 100$ cannot be due to an electrogenic $\mathrm{Na}^{+}$ transport.

A logical conclusion would be that the $\mathrm{E}_{+100}$ is due to an electrogenic $\mathrm{K}^{+}$transport into the endolymph. Such a potential has so far only been found in the midgut of the silkworm (Hyalophora cecropia) (Haskell et al., 1965. Wood et al., 1969) In that case the potential was sensitive to anoxia, but not to $10+\mathrm{M}$ ouabain. Although there is as yet no precedent for an ouabain-sensitive electrogenic $\mathrm{K}^{+}$pump, there is some experimental evidence in favour of this assumption First, ${ }^{42} \mathrm{~K}$ injected into the scala vestibuli rapidly appeared in the stria vascularis and in the endolymph, and this transport could be inhibited by ouabain (Rauch, 1966). Secondly after 30 minutes of anoxemia the decrease in the $\mathrm{K}^{+}$concentration of the endolymph is larger than the increase in 
the $\mathrm{Na}^{+}$concentration (Bosher and Warren, 1968; Mendelsohn and Konishi, 1969), which suggest that the pump rate for $\mathrm{K}^{-}$is higher than for $\mathrm{Na}^{+}$. Thirdly, the $\mathrm{E}_{+} 100$ would be high enough to maintain a large part of the $\mathrm{Na}^{+}$gradient, because the $\mathrm{Na}^{+}$equilibrium potential, i.e. the potentral that is just sufficient to maintain the observed $\mathrm{Na}^{+}$gradient (endolymph $1 \mathrm{mM}$, perilymph $136 \mathrm{mM}$ ), is about $+135 \mathrm{mV}$. (Bosher and Warren, 1968). Thus the maintenance of the $\mathrm{Na}^{+}$gradient would require only a minor $\mathrm{Na}^{+}$pump activity.

$\mathrm{Cl}^{-}$ions will tend to leak into the endolymph because of the high positive potential in this compartment However, the actual $\mathrm{Cl}^{-}$concentrations in the endolymph and perilymph are about equal. This suggests the existence of a $\mathrm{Cl}^{-}$pump which extrudes $\mathrm{Cl}^{-}$from the endolymph. as has previously been suggested by Johnstone (1967).

The increase of $E_{+100}$ during perfusion of $\mathrm{K}^{+}$Ringer ( $F_{1 g} .35$ ) appeared to be much faster than that of $\mathrm{E}_{-} 20$ under the same circumstances ( $\left.F_{1 g} .42\right)$. The slower increase of $E_{-20}$ may be due to an effect of $\mathrm{Cl}^{-}$. When the cochlear potential becomes negative, $\mathrm{Cl}^{-}$ions will move out of the scala media and create a $\mathrm{Cl}^{-}$concentration gradient between endolymph and blood and perilymph. This gradient could result in a small $\mathrm{Cl}^{-} \mathrm{d}_{1}$ ffusion potential, negative with respect to the perilymph. This small potential may also explain why the $E_{-20}$ could never be completely abolished by perfusion with $\mathrm{K}^{+}$Ringer.

The decrease of the ERP after rupturing Reissner's membrane may be largely due to a deleterious effect of a low $\mathrm{K}^{+}$-high $\mathrm{Na}^{+}$medium on the stria vascularis. Duvall (1968), demonstrated that within a few hours after rupturing Reissner's membrane the stria vascularis showed degenerative changes. Moreover. Konıshı et al. (1966) showed that when the scala media was perfused with high $\mathrm{Na}^{+}$solutions for about 30 minutes the ERP decreased slowly. This decrease could not be reversed by subsequent perfusion of high $\mathrm{K}^{+}$Ringer. The abolishing of the $\mathrm{Na}^{+}$gradient after rupturing Reissner's membrane could contribute another few $\mathrm{mV}$ to the decrease in potential.

The slight effect of $\mathrm{CO}_{22}$ inhalation and acetazolamide on the potential suggests that carboanhydrase presumably is only involved in maintaining the $\mathrm{pH}$ of the cell. Prolonged inhibition of this enzyme may result in a change in the inic composition of the endolymph, as found by Erulkar and Maren (1961), but only secondarily through an effect of the change in intracellular $\mathrm{pH}$ on cell metabolism.

Thus we feel that the ERP can be interpreted as the sum of a larger positive potential $\left(E_{+}+100\right)$ due to an ouabain-sensitive, electrogenic $\mathrm{K}^{+}$pump and a smaller negative $\mathrm{K}^{-} \mathrm{d}_{1} f$ fusion potential $\left(\mathrm{E}_{-}{ }_{20}\right)$. In addition we must assume an active $\mathrm{Cl}^{-}$and $\mathrm{Na}^{+}$transport out of the endolymph, which may be coupled. Diffusion potentials for $\mathrm{Na}^{+}, \mathrm{Cl}^{-}$ and $\mathrm{H}^{+}$do not seem to contribute to the ERP to a significant extent 
Certainty about these conclusions could be obtained by placing the stria vascularis with underlying ligamentum spirale in an Ussing chamber and measuring individual ion fluxes, potentials and shortcircuit current. Our attempts to do this have failed probably due to the smallness or fragility of the structure. 
The cochlea contains two fluid compartments One of these fluids, the endolymph, has an ionic composition as found inside cells. high potassium and low sodium content. The ionic composition of the perilymph is similar to that of other extracellular fluids. Some characteristic electrical potentials occur in the cochlea, which depend on the ionic composition of the cochlear fluids, and which are essential for the auditory process.

In most cells the high $\mathrm{K}^{+}$and the low $\mathrm{Na}^{+}$concentration is maintained by a cation pump, which is closely related or even identical with a $\mathrm{Na}^{+}-\mathrm{K}^{+}$-activated ATPase system, which is specifically inhibited by ouabain and other cardiac glycosides.

In this thesis we have looked for a possible role of the $\mathrm{Na}^{+}-\mathrm{K}^{+}$ATPase system in the maintenance of the high $\mathrm{K}^{+}$and low $\mathrm{Na}^{+}$concentration of the endolymph. In addition, after establishing the presence of this enzyme system, the relationship between the $\mathrm{Na}^{+}-\mathrm{K}^{+}$ATPase system and the endolymphatic resting potential (ERP) and the cochlear microphonic potential (CMP) has been studied. This was investigated by perfusing the perilymphatic space with ouabain. The nature of the ERP was studied by changing the electrolyte composition of the perilymph, by rupturing Reissner's membrane and by application of anoxemia and ouabain.

In Chapter I our current knowledge of the anatomy of the cochlear structures is described In Chapter II the composition and circulation of the cochlear fluids are discussed. The electrical potentials observed in the cochlea are reviewed in Chapter III. In Chapter IV the occurrence and properties of the $\mathrm{Na}^{+}-\mathrm{K}^{+}-\mathrm{AT}$ Pase system are described as well as its relation to cation transport. The methods used in our experiments are described in Chapter V.

The distribution and properties of the $\mathrm{Na}^{+}-\mathrm{K}^{+}$-ATPase activity in the cochlear structures of the chicken and the guinea pig are reported in Chapters VI and VII, respectively. The enzyme system was shown to be present in very high activity in the stria vascularis of the guinea pig and in the comparable structure of the chicken, the tegmentum vasculosum, while the enzyme activity of the other cochlear structures was rather low. This points to stria vascularis and tegmentum vasculosum as the site of the cation pump involved in endolymph formation. 
In Chapter VIII the effect of ouabain on the cochlear potentials in the guinea pig is described. Both the ERP and the CMP appeared to be affected strongly and to the same extent by ouabain. There was a remarkable similarity in the effect of ouaban on both potentials and on the $\mathrm{Na}^{+}-\mathrm{K}^{+}-$ATPase activity. The $\mathrm{pI}_{50}$ for the CMP, the ERP and the $\mathrm{Na}^{+}-\mathrm{K}^{+}-\mathrm{ATPase}$ activity were $5.5,5.4$ and 5.5 respectively. Thus, it was concluded that these potentrals are dependent on the functioning of the $\mathrm{Na}^{+}-\mathrm{K}^{+}-\mathrm{ATP}$ ase system in the stria vascularis.

In Chapter IX the nature of the ERP is studied. The effects on the ERP of $\mathrm{pH}$ changes of anoxemia, cyanide and lactic acid, of rupturing Reissner's membrane and of changes in the electrolyte composition of the perilymph are reported. From these experiments it was concluded that the ERP is composed of a negative $\mathrm{K}^{+}$-diffusion potential and a positive potential due to an ouabain-sensitive electrogenic $\mathrm{K}^{+}$pump. represented by the $\mathrm{Na}^{+}-\mathrm{K}^{+}-\mathrm{ATP}$ ase system in the stria vascularis. In addition, an active $\mathrm{Cl}^{-}$extrusion from the endolymph, possibly coupled with active $\mathrm{Na}^{+}$extrusion, was postulated in order to explain some of the observations. 
De cochlea bevat twee vloeıstofcompartımenten. Eén van deze vloelstoffen, de endolymphe, heeft een katıonensamenstelling zoals die gevonden wordt in de cel. hoog kalium- en laag natriumgehalte. De per1lymphe heeft een kationensamenstelling die gelı $\mathrm{k}$ is aan die van andere extracellulaire vloeistoffen. In de cochlea zın verder enige karakteristıeke elektrische potentialen aanwezıg, die afhankelık zıjn van de kationensamenstelling van de cochlearre vloeistoffen, en die van essentieel belang zijn voor het functioneren van het binnenoor.

In de meeste cellen wordt de hoge concentratie aan $\mathrm{K}^{+}$-1onen en de lage concentratie aan $\mathrm{Na}^{+}$-1onen in stand gehouden door een kationenpomp. Deze pomp is nauw verwant of zelfs identiek aan het $\mathrm{Na}^{+}-\mathrm{K}^{-}$ geactiveerde ATPase, dat specifiek geremd wordt door ouabane en andere hartglycosiden.

In dit onderzoek werd nagegaan of het $\mathrm{Na}^{+}-\mathrm{K}^{+}$geactiveerde ATPase ook een rol speelt bij het in stand houden van de hoge $\mathrm{K}^{+}$en de lage $\mathrm{Na}^{+}$-concentratie van de endolymphe. Daarnaast werd, nadat de aanwezigheid van het enzymsysteem was aangetoond, de afhankelıkheıd van de cochlearre potentialen van het functioneren van het $\mathrm{Na}^{+}-\mathrm{K}^{+}$ATPase systeem bestudeerd. Hiertoe werd het effect van ouabaine perfusie door de perilymphatische ruimte op de endolymphatische rustpotentiaal (ERP) en de cochleaire microphonische potentiaal (CMP) nagegaan. De aard van de ERP werd bestudeerd door wijziging van de electrolytsamenstelling van de perilymphe, door verwijdering van het membraan van Reissner, en door toepassing van anoxaemie en ouabaine.

In hoofdstuk I wordt een overzicht gegeven van de anatomie van de verschillende cochlearre structuren. In hoofdstuk II worden samenstelling en circulatie van de cochleare vloeistoffen besproken De cochlearre potentialen worden beschreven in hoofdstuk III Hoofdstuk IV geeft een overzicht van het voorkomen en de eigenschappen van het $\mathrm{Na}^{+}-\mathrm{K}^{+}$-ATPase en zijn relatie tot het transport van $\mathrm{Na}^{+}$en $\mathrm{K}^{+}$. De in dit onderzoek gebruikte methodieken worden besproken in hoofdstuk V.

De aanwezıgheid, de eigenschappen en de verdeling van het $\mathrm{Na}^{+}-\mathrm{K}^{+}$ geactiveerde ATPase over de verschillende cochleaire structuren worden beschreven in de hoofdstukken VI en VII respectievelı)k voor de 
cochlea van het kuken en van de cavia Het enzymsysteem blıkt in zeer hoge concentratie aanwezig te zijn in de stria vascularis van de cavia en in het hiermee vergelıkbare tegmentum vasculosum van het kuken, terwil de activiteit in de overige cochlearre structuren hiermee vergeleken bijzonder laag is. Dit duidt de stria vascularis en het tegmentum vasculosum aan als de plaats van de kationenpomp, betrokken bij de vorming van de endolymphe

In hoofdstuk VIII wordt het effect van ouabaine op de cochleare potentialen van de cavia beschreven Zowel de ERP als de CMP bleken sterk en in dezelfde mate beinvloed te worden door ouabaine. $\operatorname{Er}$ is een sterke overeenkomst in het remmend effect van ouabaine op de cochleaire potentialen en op het $\mathrm{Na}^{+}-\mathrm{K}^{+}$geactiveerde ATPase systeem. De $\mathrm{pI}_{50}$ voor de CMP. de ERP en het $\mathrm{Na}^{+}-\mathrm{K}^{+}-\mathrm{ATP}$ ase zın respectievelijk 5,5, 5,4 en 5,5 Hieruit werd geconcludeerd dat de potentialen afhankelıjk zıjn van het functioneren van het $\mathrm{Na}^{+}-\mathrm{K}^{+}-\mathrm{ATPase}$ in de stria vascularis.

In hoofdstuk IX wordt de aard van de ERP bestudeerd. De effecten op de ERP van $\mathrm{pH}$ veranderingen, van anoxaemie, cyanıde en melkzuur, van verwijderıng van de membraan van Reissner en van veranderingen in de electrolytsamenstelling van de perilymphe worden beschreven Uit deze resultaten werd geconcludeerd dat de ERP bestaat uit de som van een negatieve $\mathrm{K}^{+}$-diffusie potentiaal en een positieve component, veroorzaakt door een ouabane-gevoelige electrogene $\mathrm{K}^{+}$-pomp. die vertegenwoordigd wordt door het $\mathrm{Na}^{+}-\mathrm{K}^{+}-\mathrm{ATP}$ ase systeem in de stria vascularıs. Bovendien werd een actieve $\mathrm{Cl}^{-}$extrusie vanuit de endolymphe, mogelijk gekoppeld met actieve $\mathrm{Na}^{+}$-extrusie, gepostuleerd ter verklaring van enkele waarnemingen. 


\section{REFERENCES}

Abdel-Latif, A. A., J. Brody and H. Ramahı (1967) - Studies on sodium-potassıum adenosine triphosphatase of the nerve endings and appearance of electrical activity in developing rat brain - J. Neurochem, 141133.

Adrian, R. H. (1956) - The effect of the internal and external potassium concentration on the membrane potential of frog muscle - J. Physiol. (London), 133631.

Ahmed, K. and J. D Judah (1965) - Identification of active phosphoprotein in a cation-activated ATPase - Bıochım. Biophys. Acta, 104112.

Albers, R. W., S. Fahn and G. J. Koval (1963) - Role of Na ions in the activation of Electrophorus electric organ ATPase - Proc. Natl. Acad. Sc1 U S., 50474.

Albers, $R W$. and G. J. Koval (1966) - Na-K actıvated ATPase of Electrophorus electric organ III An associated K activated neutral phosphatase - J. Biol Chem., 2411896.

Albers, R W., G. J. Koval and G. J. Siegel (1968) - Interaction of ouabain and other cardioactive steroids with Na-K activated ATPase - Molec Pharmacol, 4. 324

Allen, G. W. (1964) - Endolymphatic sac and cochlear aqueduct. Their role in the regulation of labyrinthine pressure - Arch. Otolaryng (Chicago), 79: 322.

Altmann, $F$. and $J G$. Waltner (1950) - Further investigations on the physiology of labyrinthine fluids - Ann. Otol., 59657.

Amerlinck, A. (1923) - Contribution à l'etude de la membrane de Reissner et de de l'epithelıum de revêtement du canal cochlearre des oiseaux - Arch Biol. (Lièqe). 33301.

Arnvig. J. (1951) - Relation of the ear to the subarachnotd space and absorption of the labyrinthine fluids - Acta Otolarynq (Stockholm). Suppl. 96.

Axelsson, A. (1968) - The vascular anatomy of the cochlea of the guinea pig and in man - Acta Otolaryng (Stockholm), Suppl. 243.

Bader, $H$ and $A . K$. Sen $(1966)-\left(K^{+}\right)$-dependent acylphosphatase as part of the $\left(\mathrm{Na}^{+}+\mathrm{K}^{+}\right)$-dependent ATPase of cell membranes - Biochim. Biophys. Acta, 118116.

Bader, H., R. L. Post and G. H. Bond (1968) - Comparison of sources of a phophorylated intermediate in transport ATPase - Biochim. Biophys Acta, 15041.

Baker, P.F (1963) - Relation between phosphorus metabolism and the Na pump in intact crab nerve - Biochım Biophys. Acta, 75287.

Baker, $P F$ and C M. Connelly (1966) - Some properties of the external activation site of the Na pump in crab nerve - J. Physiol. (London), 185270.

Baker, E. and W. J. Simmonds (1966) - Membrane ATPase and electrolyte levels in marsupial erythrocytes - Biochim. Biophys. Acta, 126. 492.

Baker, P. F., M P. Blaustein, R. D. Keynes, J. Manil, T. I. Shaw and R. A. Steinhardt (1969) - The ouabain sensitive fluxes of sodium and potassium in squid giant axons - J Physiol (London), 200459.

Bakkeren, J $A$ J.M. (1968) - Active cation transport and $\left(\mathrm{Na}^{+}-\mathrm{K}^{+}\right)$-activated ATPase in rat liver - Thesis, Univ of Nijmegen Nijmegen, The Netherlands.

Bakkeren, J. A J. M. and S. L. Bonting (1968) - Studies on Na-K activated 
ATPase. XX. Properties of $\left(\mathrm{Na}^{-1}-\mathrm{K}^{+}\right)$-activated ATPase in rat liver - Biochim. Bıophys. Acta, 150460.

Bast, T. H. and B J. Anson (1949) - The temporal bone and the ear - C. C. Thomas, Springfield

Beal, D. D. (1968) - Effect of endolymphatic sac ablation in the rabbit and cat Acta Otolaryng (Stockholm), 66. 33.

Bckesy, G. von (1952) - DC resting potentials inside the cochlear partition - J. Acoust Soc. Amer, 2472.

Békesy. G. von (1960) - Experıments in hearıng - McGraw-Hill, New York.

Berg. G. $G$ and $B$ Chapman (1965) - The sodium and potassium activated ATPase of intestinal epithelium. I Location of enzymatic activity in the cell. - J Cell. Comp Physiol., 65361 .

Bıgnamı, A., G. Palladint and $G$ Venturın (1966) - Na-K ATPase in the developing chick brain - Brain Res. 3207

Bonting. S. L. and 1. $M$ Rosenthal (1960) - Effect of the method of tissue preparation on the assay of tissue enzyme activities - Nature, 185686.

Bontıng, S. L. and $B R$ Mayron (1961) - Construction, calibration and use of a modified quartz fiber fishpole" ultramicrobalance - Microchem. J., 531.

Bonting, S L, K. A Stmon and N. M. Hawkins (1961a) - Studies on sodium-potassium activated adenosinetriphosphatase no I Quantitative distribution in several tissues of the cat - Arch Biochem, 95416.

Bontıng, S L., K A. Simon and L. L Caravaggıo (1961b) - Na-K activated ATPase and active cation transport - Abstracts 1st Ann. Mtg. Amer. Soc. Cell Bicl , Chicago, p 19.

Bontıng. S L. L. L. Caravaggıo and N. M. Hawkıns (1962) - Studies on sodiumpotassium activated adenosinetriphosphatase no. IV. Correlation with cation transport sensitive to cardiac glycosides - Arch. Brochem, 98413.

Bonting. S. $L$ and $L$ L. Caravaggto (1963) - Studies on sodium-potassium activated adenosinetriphosphatase no. V. Correlation of enzyme activity with cation flux in six tissues - Arch Biochem., 10137.

Bonting. S L. L L Caravaggio and N. M Hawkıns (1963) - Studies on sodiumpotassium activated adenosinetriphosphatase no. VI. Its iole in cation transport in the lens of cat, calf and rabbit - Arch Biochem, 10147.

Bonting, $S$. $L$ and B. Becker (1964) - Studies on sodium-potassium activated adenosine-triphosphatase no XIV. Inhibition of enzyme activity and aqueous humor flow in the rabbit eye after intravitreal injection of ouabain - Invest. Ophthal., 3523.

Bonteng. S. L. and M. R. Canady (1964) - Na-K activated ATPase and sodium transport in toad hladder (Studies on Na-K activated ATPase. XII) - Amer. J Physiol., 2071005.

Bonting, S $I$, , I L Caravaggio, $M R$. Canady and $N$ M. Hawkens (1964a) Studies on scdium-potassium activated adenosinetriphosphatase no. XI. The salt qland of the herring qull - Arch. Brochem, 10649.

Bonting. S. L., N M Hawkins and $M R$. Canady (1964b) - Studies of sodiumpotassium activated adenisinetriphophatase. VII. Inhibition by erythrophleum alkaloids - Brochem Pharmacol., 1313.

Bontung, S. L., L. L. Caravaggıo and M. R. Canady (1964c) - Studies on Na-K activated adenosinetriphosphatase no. $X$. Occurrence in retınal rods and relaticn to rhodopsin - Exptl Eye Res., 347.

Bontıng, $S L$ (1966) - Studies on sodıum-pctassıum actıvated adenosinetriphosphatase no XV. The rectal gland of the elasmobranchs - Comp. Biochem. Physiol., 17953

Borghesan, $E$ (1957) - Modality of the cochlear humoral circulation - Laryngoscope, 671266 . 
Bosher, S. K. and R. L. Warren (1968) - Observations on the electrochemistry of the cochlear endolymph of the rat. a quantitative study of its electrical potential and ionic composition as determined by means of flame spectrophotometry - Proc. Roy Soc. (Brol.), 171. 227.

Bulget, R. E. (1963) - Fine structure of the rectal (salt secreting) gland of the spiny dogfish. Squalıs acanthias - Anat. Rec., 147: 95.

Butler, R. A., V. Honrubia, B. M. Johnstone, and C. Fernández (1962) - Cochlear function under metabolic impairment - Ann. Otol., 71. 648.

Butler, R. A. (1965) - Some experimental observations on the resting potentials in the guinea pıg cochlea - J. Acoust. Soc. Amer., 37. 429.

Caldwell, P. C., A. L Hodgkin, R. D. Keynes and T. I. Shaw (1960) - The effects of injecting "energy-rich" phosphate compounds on the active transport of ions in the grant axons of loligo - J. Physiol. (London), 152561.

Chambers, A. H. and G. G Lucchina (1966) - Effects of dinitrophenol on cochlear potentials of the cat - J. Audit. Res., 6: 13.

Charnock, J. S. and R. L. Post (1963) - Evidence of the mechanism of ouabain inbibition of cation-activated ATPase - Nature, 199: 910.

Choo, Y. B. and D. Tabowitz (1964) - The formation and flow of the cochlear fluids $\left(\mathrm{Na}^{222}\right)$ - Ann. Otol., 73: 92.

Choo, Y. B. and D. Tabowitz (1965) - The formation and flow of the cochlear fluids $\left(\mathrm{K}^{\mathrm{2}}\right)$ - Ann. Otol., 74. 140.

Chou, J. T. Y. and K. Rodgers (1962) - Respiration of tissues lining the mammalian membranous labyrinth - J. Laryng., 76: 341.

Chou, J. T. Y. (1963) - Respiration of Reissner's membrane of the guinea pig J. Laryng., 77, 374.

Citron, L. and D. Exley (1957) - Recent work on the biochemistry of the labyrinthine fluids - Proc. Roy. Soc. Med., 50: 697.

Cole, D.F. (1961) - Electrochemical changes associated with the formation of the aqueous humor - Brit. J. Ophthal., 45. 202.

Corrie, $W . S$. and $S . L$. Bonting (1966) - Studies on $\left(\mathrm{Na}^{+}-\mathrm{K}^{+}\right)$-activated adenosinetriphosphatase no. XVII. Effect of oubain and erythrophleine on $\mathrm{K}$ concentration and membrane potential of frog sartorius muscle - Biochim. Biophys. Acta, 120. 91.

Crane, $R . V .(1965)$ - Sodium dependent transport in the intestine and other anımal tissues - Fed. Proc., 24. 1000.

Cummins, J. and H. Hyden (1962) - ATP levels and ATPase in neurons, glia and neuronal membranes of the vestibular nucleus - Biochim. Biophys. Acta, 60: 271.

Davis, H, I. Tasaki, C. A. Smith and G. H. Deatherage (1955) - Cochlear potentials after intracochlear injections and anoxia — Fed. Proc., 14. 112.

Davis, H. (1957) - Biophysics and physiology of the inner ear - Physiol. Rev., 37. 1.

Davis, H., B. H. Deatherage, B. Rosenblut, C. Fernández, R. Kimura and C. A. Smith (1958) - Modification of cochlear potentials produced by streptomycin poisoning and by extensive venous obstruction - Laryngoscope, 68: 596.

Davis, H. (1961) - Some principles of sensory receptor action - Physiol. Rev., 41: 391 .

Dohlman, G. and F. C. Ormerod (1960) - The secretion and absorption of endolymph - Acta otolaryng. (Stockholm), 51: 435.

Dohlman, G. F. (1965) - The mechanism of secretion and absorption of endolymph in the vestibular apparatus - Acta Otolaryng. (Stockholm), 59. 275.

Doi, S. (1939) - Über die freien Zellen im Saccus endolymphaticus der Meerschweinchen - Zbl. Hals. Nas. Ohrenheilk., 31: 329. 
Doyle, W. L. (1960) - The principal cells of the salt-gland of marine birds - Exp. Cell Res., 21: 386.

Dunham, E. T. and I. M. Glynn (1961) - Adenosinetriphosphatase activity and the active movement of alkali metal ions - J. Physiol. (London), 156: 274.

Duvall, A. I. and V. T. Rhodes (1967a) - Reissner's membrane. An ultrastructural study - Arch. Otolaryng. (Chicago), 86: 143.

Duvall, A. J. and V.T. Rhodes (1967b). Ultrastructure of the organ of Corti following intermixing of cochlear fluids - Ann. Otol., 76: 688.

Duvall, A. J. (1968) - UItrastructure of the lateral cochlear wall following intermixing of fluids - Ann. Otol, 77: 317.

Ebner, V. von (1903) - Schnecke und Schneckengang. In: Köllikers Handbuch der Gewebelehre des Menschen - W. Engelmann, Leipzig, Bd. III, 2.

Eggemann S. and W. Bruchmüller (1968) - Die kohlensäureanhydratase im Innenohr des Meerschweinchens und ihre Hemmung. - Arch. Klin. Exp. Ohr. Nas. Kehlkopfheilk., 190: 450.

Emmelot, P. and C. J. Bos (1966) - Plasma membranes. 1II. Mgq+-ATPase, $\left(\mathrm{Na}^{+}-\mathrm{K}^{+}-\mathrm{Mg}^{2+}\right)$-ATPase and $5^{\prime}$-nucleotidase activity of plasma membranes from rat liver - Biochim. Biophys. Acta, 120: 369.

Engström, H., H.W. Ades and A. Andersson (1966) - Structural pattern of the organ of Corti - Almquist and Wiksell, Stockholm.

Epstein. F. H. and R. Whittam (1966) - Mode of inhibition by calcium of cellmembrane adenosinetriphosphatase activity - Biochem. J., 99: 232.

Erulkar, S. D. and T. H. Maren (1961) - Carbonic anhydrase and the inner ear Neture, 189: 459.

Fahn, S., G. J. Koval and R. W. Albers (1968) - Na-K activated ATPase of Electrophorus electric organ. V. Phosphorylation by ATP_is P. - J. Biol. Chem., 243: 1993.

Farquhar, M. G. and G. E. Palade (1963) - Junctional complexes in various epithelia - J. Cell. Biol., 17: 375.

Fernández, C. (1952) - Dimensions of the cochlea (guinea pig) - J. Acoust. Soc. Amer., 24: 519.

Fernández, C. (1967) - Biochemistry of labyrinthine fluids. Inorganic substances Arch. Otolaryng. (Chicago), 86: 222.

Fletcher, G. L., I. M. Stainer and W. N. Holmes (1967) - Sequential changes in the adenosine triphosphatase activity and the eletrolyte excretory capacity of the nasal glands of the duck (Anas Platyrhynchos) during the period of adaptation to hypertonic saline - J. Exp. Biol., 47: 375.

Gárdos, G. (1954) - Accumulation of $\mathrm{K}^{+}$ions in human blood cells - Acta Physiol. Acad. Sci. Hung., 6: 191.

Garrahan, P. I. and I. M. Glynn (1967a). The behaviour of the sodium pump in red cells in the absence of external potassium - J. Physiol. (London), 192: 159.

Garrahan, P. J. and I. M. Glynn (1967b) - Factors affecting the relative magnitudes of the sodium : potassium and sodium : sodium exchanges catalysed by the sodium pump - J. Physiol. (London), 192: 189.

Guild, S. R. (1927) - The circulation of the endolymph - Amer. J. Anat., 39: 57.

Hafkenscheid, J. C. $M$. and S. L. Bonting (1968) - Studies on $\left(\mathrm{Na}^{+}-\mathrm{K}^{+}\right)$-activated ATPase, no. XIX. Occurrence and properties of a $\left(\mathrm{Na}^{+}-\mathrm{K}^{+}\right)$-activated ATPase in escherichia coli - Biochim. Biophys. Acta, 151: 204.

Hafkenscheid. J. C. M. and S. L. Bonting (1969) - Studies on Na-K activated adenosine triphosphatase no. XXIII. A $\mathrm{Mg}^{2+}$ ATPase in E. Coli, activated by monovalent cations - Biochim. Biophys. Acta, 178: 128. 
Hagıwara, S. and N. Saito (1959) - Voltage-current relations in nerve cell membrane of onchidium veruculatum - J. Phystol. (London). 148: 161.

Haskell, J. A., R. D. Clemons and W. R. Harvey (1965) - Active transport by the cecropia midgut. I. Inhibitors, stimulants, and potassium-transport - J. Cell. Physiol., 65: 45.

Heinz, E. and J. F. Hoffman (1965) - Phosphate incorporation and Na-, K-ATPase activity in human red blood cell ghosts - J. Cell Physiol., 6531.

Held, H. (1926) - Die Cochlea der Sauger und der Vogel, ihre Entwicklung und ihr Bau. In. Handbuch der normale und pathologische Physılogie - Springer, Berlin, Bd, 11· 467.

Herrera, F. C. (1968) - Bicelectric properties and ionic content in toad bladder J. Gen. Physiol., 51. 261.

Hinojosa, R. and E. L. Rodriguez-Echandta (1966) - The fine structure of the stria vascularis of the cat inner ear - Amer. I. Anat., 118. 631.

Hodgkin, A. L. and B. Katz (1949) - The effect of sodium ions on the electrical activity of the grant ax on the squid - J. Physiol. (London), 108: 37.

Hodgkin, A. L. and R. D. Keynes (1955) - The potassium permeability of a grant nerve fibre - J. Physiol. (London), 128: 61.

Hoffman, I. F. (1962) - Cation transport and structure of the red-cell plasma membrane - Circulation, 26. 1201.

Hokin, M.R. (1963) - Studies on a $\mathrm{Na}^{+}-\mathrm{K}^{+}$dependent, ouabain-sensitive adenssinetriphosphatase in the avian salt gland - Biochim. Biophys. Acta, 77 108.

Honrubra, V., B. M. Johnstone and R. A. Butler (1965) - Maintenance of cochlear potentials during asphyxia - Acta Otolaryng. (Stockholm), 60: 105.

Hughes, D. G. and J. T. Y. Chou (1963) - The origin of the perilymph of the inner ear - Life Sci., 2: 107.

Iinuma, T. (1967) - Evaluation of adenosinetriphcsphatase activity in the stria vascularis and spiral ligament of normal guinea pigs - Laryngoscope, 77: 141.

Iinuma, T. and J. F. Daly (1968) - Evaluation of alkalıne and actd phosphatases activity in the stria vascularis and spiral ligament of normal gunea p:gs - Laryngoscope, 781677 .

Ilberg. C. von, and A. Imamura (1966) - Ein methodischer Beitrag zur Permeabilitatsmessung an der Reissner-Membran - Arch. Klin. Exp. Ohr. Nas. Kehlkopfheilk., 187: 800

Ilberg, C. von (1968a) - Elektronenmikroskopische Untersuchung über Diffusion und Resorption von Thoriumdioxyd an der Meerschweinchenschnecke. II. Reissnersche Membran - Arch. Klin. Exp. Ohr. Nas. Kehlkopfhellk., 190426.

Ilberg. C. von (1968b) - Elektronenmikroskopische Untersuchungen uber Diffusion und Resorption von Thoriumdioxyd an der Meerschweinschenschnecke. I. Ligamentum sptrale und Stria vascularis - Arch. Klin. Exp. Ohr. Nas. Kehlkopfheilk., 190415.

Ilberg. C. von (1968c) - Elektronenmikroskopische Untersuchungen uber Diffusion und Resorption von Thoriumdioxyd an der Meerschweinchenschnecke. III. Limbus spiralis - Arch. Klin Exp Ohr. Nas. Kehlkoptheilk., 192163.

Ilberg. C. von (1968d) - Elektronenmikroskopische Untersuchungen uber Diffusion und Resorption von Thorıumdioxyd an der Meerschweinchenschnecke. IV. Basılar Membran und Cortisches Organ - Arch. Klin. Exp. Ohr. Nas. Kehlkopfheilk., 192: 384.

Ilberg, C. von, $H$. Spoendlin and K. H. Vosteen (1968) - Die Ultrastruktur und Funktion des Sulcus spiralis externus und der Prominentia spiralis der Meerschweinchenschnecke. Darstellung mittels Thorotrast - Arch. Klın. Exp. Ohr. Nas. Kehlkoptheilk., 192: 124. 
Ishit, $T H$ Silverstein and $K$ Balogh jr (1966) - Metabolic activities of the endolymphatic sac - Acta Otolaryng (Stockholm). 6261

Ishu, $T$ and $Y$ Nomura (1968) - Histochemical study on adenosinetriphosphatase activity in the inner ear - Pract Otorhinolaryng (Basel), 30237

Iurato $S$ (1967a) - Submicroscopic structure of the inner ear - Pergamon, Oxford

Iturato, S (1967b) - Elektronenoptische Struktur der Innenohr-Membranen mit Ruckschlussen auf thre Eignung zum Stoffaustausch - Arch Klın Exp Ohr Nas Kehlkopfheslk , 189113

Jahnke $V$ P G Lundquist and J Wersull (1969) Some morpholoqical aspects of sound perception in birds - Acta Otolaryng (Stockholm), 67583

Jarnefelt, J (1961) - ATP dependent binding of Na by microsomes from brain Biochem Biophys Res Commun, 6285

Johnson, $R L$ and $H H$ Spoendlin (1966) - Structural evidence of secretion in the strıa vascularıs - Ann Otol 75127

Johnstone C G, RS Schmidt and B M Johnstone (1963) - Sodium and potassium in vertebrate cochlear endolymph as determined by flame microspectrophotometry - Comp Biochem Physiol 9335

Johnstone $B M$ (1965) - The relation between endolymph and the endocochlear potential during anoxia - Acta Otolaryng (Stockholm) 60113

Johnstone. J $R$ and $B M$ Johnstone (1966) - Origin of summating potential - J Acoust Soc Amer 401405

Johnstone $B M J R$ Johnstone and I D Pugsley (1966) - Membrane resistance in endolymphatic walls of the first turn of the guinea pig cochlea - J Acoust Soc Amer 401398

Johnstone, $B M$ (1967) - Genesis of the cochlear endolymphatic potential - Curr Topics in Bioenerg 2335

Judah, I $D$ and $K$ Ahmed (1964) - Inhibitors of transport and cation activated ATP-ases - J Cell Comp Physıol, 64355

Katsukt Y K Yanagısawa and J Kanzakı (1966) - Tetraethylammonum and tetrodotoxin effects on cochlear potentials - Science 1511544

Katz $A I$ and $F H$ Epstein (1967) - Role of sodium-potassium activated adenosine triphosphatase in reabsorption of sodium by kıdney - J Clın Invest, 461999

Kikirch, $K$ and $D A$ Hilding (1967) - The spiral vessel and stria vascularis in shaker-1 mice - Acta Otolaryng (Stockholm). 63395

Kimura, $R S$ (1967) - Experimental blockage of the endolymphatic duct and sac and its effect on the inner ear of the guinea pig - Ann Otol, 76664

Ktmura $R S$ (1969) - Distribution structure and function of dark cells in the vestıbular labyrinth - Ann Otol 78542

Kirtkae, I Y Nomura M Nagakura I Matsuba and S Sugiura (1961) - A consideration on the circulation of the perilymph An experimental study - Ann Otol, $70 \quad 373$

Koburg $E$ (1961) - Autoradıoqraphische Untersuchungen zum Nukleınesaurestoffwechsel der Gewebe der Cochlea - Arch Klın Exp Ohr Nas Kehlkopfheilk 178150

Koburg $E$ and $D$ Plester (1962) - Zur Grosse des Elweissstofwechsels der Gewebe der Cochlea Autoradiographische Untersuchungen an Meerschweinchen mit H'Lysin - Acta Otolaryng (Stockholm), 54319

Koefoed-Johnsen, $V$ (1957) - Effect of g-strophantın (ouabain) on the active transport of sodium through the isolated frog skin - Acta Physiol Scand, 42 Suppl 14587

Komnıck, $H$ and $U$ Komnick (1963) - Elektronenmikroskopische Untersuchungen 
zur funktionellen Morphologie des Ionentransportes in der Salzdrüse von Larus argentatus - Z. Zellforsch, 60: 163.

Konishi, T., R. A. Butler and C. Fernández (1961) - Effect of anoxia on cochlear potentials - J. Acoust. Soc. Amer., 33: 349.

Konishi, T. and T. Yasuno (1963) - Summating potential of the cochlea in the guinea pig - I. Acoust. Soc. Amer., 35: 1448.

Konishi, T., E. Kelsey and G. T. Singleton (1966) - Effects of chemical alteration in the endolymph on the cochlear potentials - Acta Otolaryng. (Stockholm), 62: 393.

Konishi, T., E. Kelsey and G. T. Singleton (1967) - Negative potential in scala media during early stage of anoxia - Acta Otolaryng. (Stockholm), 64: 107.

Konishi, T. and E. Kelsey (1968a) - Effect of sodium deficiency on cochlear potentials - J. Acoust. Soc. Amer., 43: 462.

Konishi, T. and E. Kelsey (1968b) - Effect of tetrodotoxin and procaine on cochlear potentials - J. Acoust. Soc. Amer., 43: 471.

Konishi, T. and E. Kelsey (1968c) - Effects of cyanide on cochlear potentials Acta Otolaryng. (Stockholm), 65: 381.

Kürschner, H. D. (1968) - Uber die Lactat- und Malatdehydrogenase in den vier Windungen der Cochlea des Meerschweinchens - Thesis, Düsseldorf.

Kuijpers, W., A. C. van der Vleuten and S. L. Bonting (1967) - Cochlear function and sodium and potassium activated adenosine triphosphatase (Studies on $\mathrm{Na}-\mathrm{K}$ activated adenosinetriphosphatase no. XVIII) - Science, 157: 949.

Kuijpers, $W$. and S. L. Bonting (1969) - Studies on $\left(\mathrm{Na}^{+}-\mathrm{K}^{+}\right)$activated ATPase no. XXIV. Localization and properties of ATPase in the inner ear of the guinea pig - Biochim. Biophys. Acta, 173: 477.

Landon, E. J. and J. L. Norris (1963) - Na- and K-dependent ATPase activity in a rat kidney endoplasmatic reticulum fraction - Biochim. Biophys. Acta, 71: 266.

Laurence, M., D. Wolsk and W. B. Litton (1961) - Circulation of the inner ear fluids - Ann. Otol., 70: 753.

Lawrence, M. (1966) - Histological evidence for localized radial flow of endolymph - Arch. Otolaryng. (Chicago), 83: 406.

Lawrence, $M$. (1967) - Electric polarization of the tectorial membrane - Ann. Otol., 76: 287.

Loewenstein, W. R., A. A. Terzuolo and Y. Washizu (1963) - Separation of transducer and impulse-generating processes in sensory receptors - Science, 142: 1180.

Lowry. O. H. (1953) - The quantitative histochemistry of the brain histological sampling - J. Histochem. Cytochem., 1: 420.

Lundquist, P. G. (1965) - The endolymphatic duct and sac in the guinea pig Acta Otolaryng. (Stockholm), Suppl. 201.

Maggio, E. (1966) - The humoral syster of the labyrinth - Acta Otolaryng. (Stockholm), Suppl. 218.

Matschinsky, F. M. and R. Thalmann (1967) - Quantitative histochemistry of microscopic structures of the cochlea - Ann. Otol., 76: 638.

Matsuura, S., K. Ikeda and T. Furukawa (1968) - Ouabain and streptomycin: their different loci of action on saccular hair cells in goldfish - Science, 160: 1117.

Mendelsohn, $M$. and T. Konishi (1969) - The effect of local anoxia on the cation content of the endolymph - Ann. Otol., 78: 65.

Meyer zum Gottesberge, A., S. Rauch and E. Koburg (1965) - Unterschiede in Metabolismus der einzelnen Schneckenwindungen - Acta Otolaryng. (Stockholm), 59: 116 .

Misrahy, G. A.. E. W. Shinabarger and I. E. Arnold (1958a) - Changes in cochlear endolymphatic oxygen availability, action potential and microphonics during 
and following asphyxia, hypoxia and exposure to loud sounds - J. Acoust. Soc. Amer., 30. 701 .

Misrahy, G. A, K M Hildreth, E W. Shinabarger and W. J. Gannon (1958b) Electrical properties of wall of endolymphatıc space of the cochlea (guinea pıg) - Amer J. Physiol, 194396.

Misrahy, G. A, K. M. Hildreth, L. C. Clark and E. W. Shincbarger (1958c) Measurement of the $\mathrm{pH}$ of the endolymph in the cochlea of guinea pigs - Amer. J. Physiol., 194393.

Mizukosht, O. and J. F. Daly (1967) - Oxygen Consumption in normal and kanamycin damaged cochleae - Acta Otolaryng. (Stockholm), 6445.

Naftalın, L. and M.S. Harrison (1958) - Circulatıon of labyrınthıne fluids - J. Laryng.. 72118.

Nakat, Y. and D. A. Hulding (1966) - Electronmicroscopic studies of adenosınetriphosphatase activity in the stria vascularis and spiral ligament - Acta Otolaryng (Stockholm), 62411.

Nakar. Y. and D Hilding (1967) - Adenosinetriphosphatase distribution in the organ of Cortı Histochemical study by light and electron microscopy - Acta Otolaryng. (Stockholm), 64477.

Nakat, $Y$. and $D A$. Hilding (1968a) - Oxydative enzymes in the cochlea: An electron microscopic and histochemical study of succinic dehydrogenase and $d_{1}$ hydronicotınamide adenine dinucleotide diaphorase - Acta Otolaryng. (Stockholm). 65459.

Nakat, $Y$ and D. Hilding (1968b) - Vestibular endolymph producing epithelium. Electron microscopic study of the development and histochemistry of the dark cells of the crista ampullaris - Acta Otolaryng. (Stockholm) 66120.

Nastuk. $W$. $L$, and $A L$ Hodgkin (1950) - The electrical activity of single muscle fibers - J. Cell. Physiol., 35. 39.

Newey, H., $P$ A Sanford and $D H$. Smyth (1968) - Some effects of ouabain and $\mathrm{K}^{+}$on transport and metabolism in rat small intestine - J. Physiol. (London), 194237.

Opit, L. J. and J. S. Charnock (1965) - A molecular model for a $\mathrm{Na}$ pump - Nature, 208471.

Oppelt, W. W. and R. F. Palmer (1966) - Stımulation of cerebrospinal flutd production by low doses of intraventricular ouabain - J. Pharmacol. Exp. Ther., 154581 .

Ozakı, $M$. and $M$. Sato (1965) - Changes in the membrane potential and the membrane conductance associated with a sustained depolarization of the non-myelinated nerve terminal in Pacinian corpuscles - J. Physiol. (London), 180. 186.

Palmer, R. F. and B. R. Nechay (1964) - Biphasic renal effects of ouabain in the chicken correlation with microsomal $\mathrm{Na}^{+}-\mathrm{K}^{+}$stımulated ATPase - J. Pharmacol. Exp Ther., 14692

Palmer, R. F. K. C. Lasseter and S. L. Melvin (1966) - Stımulation of $\mathrm{Na}^{+}-\mathrm{K}^{+}$ dependent adenosinetriphosphatase by ouabain - Arch. Biochem., 113. 629.

Patlak, C. S. (1964) - Potential difference of the ventricular fluid in vivo and in vitro in the dogfish - Fed. Proc, 23. 211.

Pease, D. C. (1955) - Electron microscopy of the tubular cells of the kidney cortex - Anat. Rec, 121. 723.

Portuis, H. I and K. Repke (1967) - Preparation of the Na-K activated, Mgdependent ATP phosphohydrolase system of heart muscle by isolation of the cell membrane - Acta Biol. Med. German., 19879.

Post, R. L, C. R. Merrit, C. R. Kinsolving and C. D. Albright (1960) - Membrane 
adenosine triphosphatase as a participant in the active transport of sodium and potassium in the human erythrocyte - I Biol Chem, 2351796.

Post, $R$ L., A K. Sen and $A S$ Rosenthal (1965) - A phosphorylated intermediate in adenosinetriphosphate-dependent sodium and potassium transport across kıdney membranes - J. Biol. Chem, 2401437.

Rauch, S. (1964) - Biochemie des Hororgans - Thieme Verlag, Stuttgart.

Rauch, $S$ and $H$ Ruska (1965) - Zur elektronenoptischen Struktur und Funktion der Strıa vascularıs - Arch. Klın Exp. Ohr. Nas. Kehlkoptheılk, 189127.

Rauch, S (1966) - Membrane problems of the inner ear and their significance J Laryng. 801144.

Rice, $E . A$ and $E$. W. Shtnabarger (1961) - Studies on the endolymphatic DC potential of the guinea pig's cochlea - J. Acoust Soc. Amer., 33922.

Ridderstap. $A S$ and $S$ L. Bonting (1969a) - Nar-K-actuvated ATPase and pancreatic secretion in the dog (Studies on $\mathrm{Na}-\mathrm{K}$ activated adenosinetriphosphatase, no. XXII) - Amer J. Physiol., 216547.

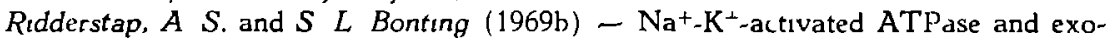
crine pancreatic secretion in vitro (Studies on $\mathrm{Na}-\mathrm{K}$ activated adenosinetriphosphatase no. XXV) - Amer. J Physiol., in press.

Rodgers, K. and J. T. Y. Chou (1966) - Concentrations of inorganic ions in guinea pig inner ear fluids II. Post-mortem changes in the ionic composition of utricular endolymph and perilymph - J Laryng, 80885.

Rodriguez Echandid, $E L$. and $M H$ Burgos (1965) - The fine structure of the stria vascularis of the guinea-pig inner ear $-Z$. Zellforsch., 67600

Rosenberg. I. H., A L. Coleman and $L E$ Rosenberg (1965) - The role of sodium ion in the transport of anımo acids by the intestine - Biochim. Biophys. Acta, 102161.

Rosenberg, I. H. and $L E$. Rosenberg (1968) - Localization and characterization of adenosıne triphosphatase in guinea pıg intestinal epithelıum - Biochem. Physıol., 24975

Roth, T.F. and K.R. Porter (1964) - Yolk protein uptake in oocyte of the mosquito aedes aegypt $-\mathrm{J}$ Cell. Bıl, 20. 313.

Schatzmann, H J. (1953) - Herzglykosıde als Hemmstoffe fur den aktıven Kalıumund Natrium Transport durch das Erythrocytenmembran - Helv. Physiol. Pharmacol. Acta, 11346

Schmıdt, $R S$ and C Fernandez (1962) - Labyrinthine DC potentials in representative vertebrates - J. Cell Physiol., 59311.

Schmidt, R. S (1963a) - Types of endolymphatıc potentials - Comp. Biochem. Physiol.. 10. 83.

Schmidt, $R S$. (1963b) - Independence of the endovestıbular potential in homeotherms - J. Gen. Physiol . 47. 371.

Schoffeniels, E. (1967) - Cellular aspects of membrane permeability - Pergamon, Oxford, p 95.

Schuknecht, $H F$. and $A$ El Setfi (1963) - Experimental observations on the fluid physiology of the inner ear - Ann Otol., 72687.

Schwartzkopl. J. and $P$ Winter (1960) - Zur Anatomie der Vogel-Cochlea unter naturlichen Bedingungen - Biol $\mathrm{Zbl}, 79607$.

Silversteın, $H$ (1966) - Biochemical and physiologic studies of the endolymphatic sac in the cat - Laryngoscope, 76498.

Skou, J. C. (1957) - The influence of some cations on an adenosine triphosphatase from perıpheral nerves - Biochım. Biophys Acta, 23394.

Skou. J. C. (1960) - Further investigations on a $\left(\mathrm{Mg}^{++}+\mathrm{Na}^{+}\right)$-activated adenosinetriphosphatase possibly related to the active linked transport of $\mathrm{Na}^{+}$and $\mathrm{K}^{-}$ across the nerve membrane - Biochim Biophys Acta, 42: 6 . 
Slegers, J. F. G. (1968) - Ionic secretion by epithelial membranes. In: Control mechanisms in cystic fibrosis - Ciba foundation, London, p. 68.

Slegers, J. F. G. and W. M. Moons (1968) - Effect of acetazolamide on the chloride shift and the sodium pump in secretory cells - Nature, 220: 181.

Smith, C. A., O. H. Lowry and M.L.Wu (1954) - The electrolytes of the labyrinthine fluids - Iarynaoscope. 64: 141.

Smith, C. A. (1957) - Structure of the stria vascularis and the spiral prominence Ann. Otol., 66: 521.

Smith, C. A., H. Davis, B. H. Deatherage and C. F. Gessert (1958) - DC potentials of the membranous labyrinth - Amer. J. Physiol., 193: 203.

Smith. C. A. and F.S. Sjöstrand (1961) - Structure of the nerve endings on the external hair cells of the guinea pig cochlea as studied by serial sections - J. Ultrastruct. Res., 5: 523.

Spoendlin, H. H. and K. Balogh (1963) - Histochemical localization of dehydrogenases in the cochlea of living animals - Laryngoscope, 73: 1061.

Spoendlin, $H$, and $W$. Lichtensteiner (1966) - The adrenergic innervation of the labyrinth - Acta Otolaryng. (Stockholm), 61: 423.

Spoendlin, H. (1967a) - Vascular stria. In: S. Iurato, Submicroscopic structure of the inner ear - Pergamon, Oxford, p. 131.

Spoendlin, H. (1967b) - The innervation of the organ of Corti - J. Laryng., 81: 717. Spoendlin, H. (1969) - Innervation patterns in the organ of Corti of cat - Acta Otolaryng. (Stockholm), 67: 239.

Tasaki, I. and C. Fernández (1952) - Modification of cochlear microphonics and action potentials by $\mathrm{KCl}$ solution and by direct currents - J. Neurophysiol., 15: 497.

Tasaki, I., H. Davis and J. P. Legouix (1952) - The space-time pattern of the cochlear microphonics as recorded by differential electrodes - J. Acoust. Soc. Amer., 24: 502.

Tasaki, I., H. Davis and D. H. Eldredge (1954) - Exploration of cochlear potentials in guinea pig with a microelectrode - J. Acoust. Soc. Amer., 26: 765.

Tasaki, I. (1957) - Hearing - Ann. Rev. Physiol., 19: 417.

Tasaki, I. and C. S. Spyropoulos (1959) - Stria vascularis as source of endocochlear potential - J. Neurophysiol., 22: 149.

Taylor, C. B. (1962) - Cation stimulation of an ATPase system from the intestinal mucosa of the guinea pig - Biochim. Biophys. Acta, 60: 437.

Terrayama, Y., E. Holz and C. Beck (1966) - Adrenergic innervation of the cochlea - Ann. Otol., 75: 69.

Thesleff, S. and K. Schmidt-Nielsen (1962) - An electrophysiological study of the salt gland of the herring gull - Amer. J. Physiol., 202: 597.

Tonndorf, J., A. J. Duvall and J. P. Reneau (1962) - Permeability of intracochlear membranes to various vital stains - Ann. Otol., 71: 801.

Tosteson, D. C., R. H. Moulton and M. Blaustein (1960) - Enzymatic basis for the difference in active cation transport in two genetic types of sheep red cells Fed. Proc., 19: 128.

Ussing. H. H. (1949) - Transport across cellular membranes - Physiol. Rev., 29 : 127.

Ussing, H.H., T.V. Biber and N.S. Bricker (1965) - Exposure of the isolated frog skin to high potassium concentration at the internal surface. II. Changes in epithelial cell volume, resistance and response to antidiuretic hormone - J. Gen. Physiol., 48: 425. 
Vanzulh, A. and E Garcta-Austt (1963) - Development of cochlear microphonic potentials in the chick embryo - Acta Neurol. Lat. Amer , 919.

Vares, $T$ S. S. L. Bonting and $W$. W. Oppeit (1964) - Na-K activated adenosinetriphosphatase and formation of cerebrospinal fluid in the cat (Studies on Na-K activated adenosinetriphophatase no IX) - Amer J. Physiol, 206. 1165.

Vosteen, K. H. (1961) - Neue Aspekte zur Biologie und Pathologie des Innenohres - Arch. Klın. Exp. Ohr. Nas. Kehlkopfheilk., 1781.

Wever, E. G. (1966) - Electrical potentials of the cochlea - Physiol. Rev., 46102.

Whittam, R. (1962) - The assymmetrical stımulation of a membrane adenosine triphosphatase in relation to active cation transport - Biochem. J., 84. 110.

Wiley. J.S. (1969) - Inheritance of an increased sodium pump in human red cells Nature, 221 1222.

Wood, J. L.. P. S. Farrand and W. R. Harvey (1969) - Active transport of potassium by the cecropia midgut. VI Microelectrode potential profile - J. Exp. Biol., 50. 169 .

Yamamoto, $K$. and Y. Nakat (1964) - Electronmicroscopic studies on the functions of the stria vascularis and the spiral ligament in the inner ear - Ann Otol., 73. 332 .

Part of the results described in this thesis have been published

W. Kuijpers, A C. van der Vleuten and S. L. Bonting (1967); W. Kuijpers and S. L. Bontıng (1969). 
De conclusie van Lawrence dat in de membrana tectoria geen rustpotentiaal aanwezig is, is zeer onwaarschijnlık.

M Lawrence, Ann Otol, 76 287, 1967

\section{II}

De veronderstelling van Ling en Cope dat het merendeel van de intracellulatre $\mathrm{K}^{+}$-ionen van de kikkerspier geadsorbeerd is aan macromoleculen, is niet in overeenstemming te brengen met het iso-osmotisch evenwicht tussen intra- en extracellulair compartiment

G N Ling en F W Cope. Science, 163 1335, 1969

\section{III}

Wanneer bij 1onentransport door brologische membranen de gemeten flux ratio overeenkomt met die berekend volgens de formule van Ussing, is er sprake van passief transport Wanneer deze overeenkomst ontbreekt, mag echter net automatisch tot het bestaan van actief transport geconcludeerd worden

\section{IV}

Op grond van de gebruikte isolatiemethode, mag de door Eaton en Moss gekarakteriseerde alkalische phosphatase activiteit niet als representatief beschouwd worden voor de alkalische phosphatase activiteit in het onderzochte bot.

R H Eaton en D W Moss, Enzymologia, 35 31, 1968

\section{V}

Gezıen de gebruikte methodieken, mag uit de experımenten van Kasbekar en Durbin net geconcludeerd worden dat er in het maagslımvlies van Rana catesbeiana geen $\mathrm{Na}^{+}-\mathrm{K}^{+}$-geactiveerd ATPase voorkomt.

D K Kasbekar en R P Durbın, Bıochım Bıophys Acta, 105 472, 1965 

De conclusie dat Streptomyces antibiotica het glycolytische systeem van de zintuigcellen van het binnenoor aantasten. berust op een foutieve interpretatie van de experimentele gegevens.

H J Meuwissen en G C Robinson, Clin Pedat (Phila), 62621967

\section{VII}

De argumenten van Goodhill voor een inductieve werkıng van de annulus tympanicus op de vorming van het trommelvlies, zijn niet overtuigend

V Goodhill Ann Otol 75 866, 1966

\section{VIII}

De veronderstelling dat de bij het syndroom van van der Hoeve en de Kleın beschreven geleıdıngshardhorendheid berust op een stapesankylose, identiek met die bij otosclerose, is zowel op klinische als op histopathologische gronden aanvechtbaar

H Wullstein R F Ogilvie en J S Hall, J Laryng, 74 67, 1960

P Clerc en L G Chevance, Ann Otolaryng (Parıs), 82 413, 1965

O Opheım, Acta Otolaryng (Stockholm), 653371968

\section{IX}

Het ontstaan van exogastrulae tıdens de embryogenese van Limnaea stagnalis na behandeling van eicellen rondom de tweede klievingsfase met $\mathrm{L}_{1} \mathrm{Cl}$ hoeft niet uitsluitend het gevolg te $z_{11}$ n van deze behandeling Dit verschijnsel kan mede veroorzaakt zijn door de samenstelling van het na de behandeling met $\mathrm{L}_{1} \mathrm{Cl}$ gebrukte kweekmedium.

W L M Geilenkırchen, J Embryol Exp Morph, 17 367, 1967

L G Barth en L J Barth, J Embryol Exp Morph, 19 387, 1968

\section{$\mathrm{X}$}

$B_{1 \jmath}$ gebruık van knaagdieren voor experımenteel onderzoek dient wegens het frequent voorkomen van otıtıs media bıj ogenschıjnlıjk gezonde dieren een otoscopısch onderzoek te gebeuren

\section{XI}

Het is in het belang van het fundamenteel onderzoek in de kliniek, de hiervoor bestaande laboratoria in een instituut samen te brengen

W Kuıpers, 1969. 


